\title{
Aeolian Archaeology: the Archaeology of Sand Landscapes in Scotland
}

\author{
edited by \\ David Griffiths, University of Oxford \\ and \\ Patrick Ashmore, Historic Scotland
}

Selected case-studies, originally given as spoken papers at a Society of Antiquaries of Scotland Specialist Seminar, hosted by Historic Scotland, Edinburgh, May 2004 
Published by the Society of Antiquaries of Scotland, www.socantscot.org with Historic Scotland, www.historic-scotland.gov.uk and the Council for British Archaeology, www.britarch.ac.uk

Editor: $\quad$ Helen Bleck

Produced by Archétype Informatique SARL, www.archetype-it.com

ISBN: 9780903903684

ISSN: $1473-3803$

Requests for permission to reproduce material from a SAIR report should be sent to the Director of the Society of Antiquaries of Scotland, as well as to the author, illustrator, photographer or other copyright holder.

Copyright in any of the Scottish Archaeological Internet Reports series rests with the SAIR Consortium and the individual authors.

Maps in the Aeolian series are reproduced from Ordnance Survey material with the permission of Ordnance Survey on behalf of The Controller of Her Majesty's Stationery Office. (C) Crown copyright 2001. Any unauthorised reproduction infringes Crown copyright and may lead to prosecution or civil proceedings. Historic Scotland

Licence No GD 03032G, 2002.

The consent does not extend to copying for general distribution, advertising or promotional purposes, the creation of new collective works or resale. 
Introduction: Aeolian Archaeology: The Archaeology of Sand Landscapes in Scotland, by David Griffiths and Patrick Ashmore . . . . . . . . . . . . . . . . . . . . . 1

The Archaeology of Sand Landscapes: Looking for an Integrated Approach, . . . . . . . . . . 9 by David Griffiths

North Atlantic Climate Change and Late Holocene Windstorm Activity in . . . . . . . . . . . 25 the Outer Hebrides, Scotland, by Sue Dawson, Alastair Dawson and Jason Jordan

Characterising Archaeology in Machair, by John Barber . . . . . . . . . . . . . . . . . 37

Archaeological Remains on Uist's Machair: Threats and Potential， . . . . . . . . . . . . .55 by Mike Parker Pearson, Jacqui Mulville, Niall Sharples and Helen Smith

Local Community Groups and Aeolian Archaeology: Shorewatch . . . . . . . . . . . . . . .87 and the Experience of the Shetland Community Archaeology Project, by Tom Dawson, Olivia Lelong and Ingrid Shearer 



\title{
Aeolian archaeology: the archaeology of sand landscapes in Scotland
}

\author{
Patrick Ashmore, Historic Scotland \\ and \\ David Griffiths, University of Oxford
}

Scottish Archaeological Internet Report 48, 2011 www.sair.org.uk 



\section{CONTENTS}

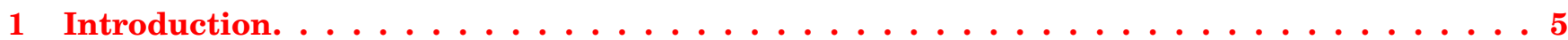

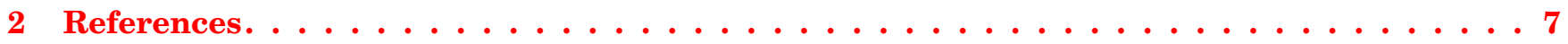





\section{INTRODUCTION}

Landscapes characterised by a substantial presence of aeolian (wind-blown) sand are predominantly coastal, and range from active dunefields with high and unstable relief, to smoother and more stable grassed surfaces which may be subject to some degree of agricultural use. Some are remote and inaccessible, but others exist in closer proximity to conurbations and tourist areas, and the impact of visitors is therefore comparatively great. In addition to the ever-present scouring and redistributing forces of sea and wind, other pressures on the stability of these landscapes include aggregates quarrying, development and the ubiquitous presence of wild burrowing fauna, most obviously the rabbit. Sand creates dynamic 'soft' landforms which are subject to continuing change, to the extent that photographs or maps of just 100 years ago often present very different topographies from those visible today. The encroachment of the sea and continual process of wind-induced change can transform a sand landscape almost overnight. In depositional strata, long periods of stasis may be represented by comparatively shallow soil horizons, which are frequently separated by much deeper bands of sand which may result from wind-blow episodes of far shorter timescale (Gilbertson et al $1996,72-8$ ). Dune systems frequently occupy zones of extensive past settlement attraction with numerous environmental advantages, and therefore occur in areas of generally high archaeological potential. Yet their complexity and extreme vulnerability present us with serious problems in terms of balancing an understanding of the archaeology with conservation strategies.

Many of our most complex ancient monuments and sites are literally built on sand, and a short excursion along almost any of Scotland's eroding sandy shores will reveal some sort of archaeological deposit in the process of weathering and crumbling away. A consensus that future climate change will dramatically increase the vulnerability of these delicate coastal landscapes by raising sea levels around Scotland, coupled with the distinct possibility of increased storminess, adds urgency to the situation. To balance the general perception of a gloomy climatological prognosis, techniques of archaeological prospection and investigation are advancing apace, offering the prospect of a much more comprehensive understanding and characterisation of the archaeological resource inherent in sand landscapes, and therefore pointing towards more informed and effective curatorial strategies in future.

Archaeological excavations of eroding Bronze Age farms and Iron Age farm mounds on the machair coast in the early 1980s have provided a wealth of detail about both archaeological potential and formation processes (Barber 2003). These excavations stemmed in part from two earlier coastal surveys, neither published. Over the past decade, however, Historic Scotland has sponsored and commissioned many Coastal Zone Assessment Surveys, all to one specification (Historic Scotland 1996), which now cover about $30 \%$ of Scotland's coastline, including many sand-covered areas. The proceedings of a seminar entitled Coastal Archaeology and Erosion in Scotland in November 1998 were published on the HS website in 2003 (Dawson (ed.) 2003) and are available in print (Dawson (ed.) 2005). The results of individual surveys are available on the SCAPE Trust website, www.scapetrust.org, and they include more recent work on the machair areas of the Uists and Benbecula, as well as surveys on Barra and Vatersay published in 1998 (Moore \& Wilson 2005; CFA Archaeology 2005; Branigan \& Grattan 1998). Other surveys, in northern Scotland, Orkney and Shetland, include smaller sand-covered areas and these too are available on the SCAPE Trust website. Historic Scotland has also grant-aided the SEARCH project almost from its inception in 1988, supporting major investigations on Barra and Vatersay (Branigan \& Foster 2000), and at Cill Donnain, Cille Pheadair (Parker Pearson \& Smith forthcoming), Dun Vulan (Parker Pearson \& Sharples 1999), Cladh Hallan and Bornais (Sharples 2005) which, taken together, provide documentation of the effects of erosion by wind and waves.

A more recent coastal conference at St Andrews, in 2004, focused more specifically on long-term issues: archaeological and cultural resource management research, community involvement and funding.

The present collection of papers stems from a one-day seminar entitled 'Aeolian Archaeology: the Archaeology of Sand Landscapes in Scotland', which was sponsored and hosted by the Society of Antiquaries of Scotland as part of its specialist seminar series and held at Historic Scotland's offices in Edinburgh on 14 May 2004. The seminar was convened and co-chaired by Patrick Ashmore and David Griffiths, and the excellent arrangements for the day itself were mostly due to the organisational skill of Fionna Ashmore, as one of the last flourishes of a distinguished term as Director of the Society of Antiquaries of Scotland before her retirement in mid-2004. The editors are grateful to her successors, Andrea Smith and Simon Gilmour, for continuing to oversee the progress of this publication.

Our motive in proposing the seminar was to learn more about the experiences of others who have been in working in sand landscapes from a variety of academic and professional backgrounds, and 
to help to establish some common methodological ways forward in understanding and characterising this most interesting but challenging type of environment. It was based upon the realisation that the accumulated wisdom of archaeologists alone was not broad enough to provide a sound basis for future research and management. The gathering was therefore consciously multi-disciplinary - too rarely do archaeologists, geomorphologists, climatologists, environmental scientists, public curators and landscape managers from diverse disciplinary backgrounds sit together in a seminar room and confront each other with the adequacy of their knowledge.

We consciously sought in the seminar to present case-studies which encompass the widest possible range of relevant methodologies, and at least to touch on most of the facets of Scotland's diverse coastal geography. Following a welcoming address by Lisbeth Thoms, President of the Society of Antiquaries, the introduction to the day and the curatorial perspective on the inherent challenges represented by sand landscapes from Historic Scotland's perspective were laid out (Ashmore). A historical and current overview of the state of archaeological methodology (Griffiths), and the accumulated benefit of long experience excavating sand sites were then provided (Barber). Lively debate followed. Recent climatological insights into historical wind-blow patterns (A Dawson), were succeeded by a summary of a recent large-scale excavation programme in machair (Parker Pearson et al). Several discussion contributions followed (all based on work published elsewhere - hence not published here): Professor William Ritchie of Aberdeen University gave an overview of his own extensive research into the geomorphology of Scottish coastal landscapes; Graeme Warren of University College Dublin summarised his research on Mesolithic archaeology in the Sands of Forvie (Aberdeenshire); Sandy Winterbottom of Stirling University gave an insight into the use of aerial remote sensing techniques in machair landscapes on Coll and Tiree (Inner Hebrides) and insights into luminescence and radiocarbon dating techniques in sand were provided by JeanLuc Schwenninger of RLAHA, Oxford, and David Sanderson of SUERC, East Kilbride. A concluding discussion rounded off the day.

Speakers were encouraged to supplement Scottish case studies with reference to relevant studies outside Scotland. It was therefore inevitable, given the broad scope of the seminar, that its detailed geographical coverage could be far from exhaustive. Many who attended the seminar but did not give papers were quite as well-qualified to do so as the speakers themselves. Areas, projects and people who have much to contribute to this debate therefore go unrepresented in the following published proceedings. However, the eventual content of the publication encompasses work which was not presented at the seminar (T Dawson et al).

The substantial body of work outlined above, and alluded to in the various papers in this publication, demonstrates that, although some sites have been deflated by aeolian erosion and other destructive processes, others contain substantial accumulations of anthropogenic and natural layers. They also demonstrate that point-in-time surveys like the Coastal Zone Assessment Surveys in this mobile environment will be difficult to compare with previous and future surveys. One challenge for the future, perhaps best addressed by geophysical techniques, will be to find efficient and economical ways of distinguishing sites where much deflation has occurred from those which retain coherent archaeological layers.

The archaeology of sand-covered areas cannot be interpreted withoutanunderstanding of siteformation processes, which are intimately bound to those of the sandy areas. The feasibility of interdisciplinary projects has been demonstrated by, for instance, the long-running SEARCH project in the Western Isles. Our hope is that publication of this seminar will help us to develop new research approaches to allow us to build on those past achievements. 


\section{REFERENCES}

Barber, J 2003 'Bronze Age Farms and Iron Age Farm Mounds of the Outer Hebrides'. SAIR 3, Society of Antiquaries of Scotland, Edinburgh.

Branigan, K \& Foster, P 2000 'From Barra to Berneray: Archaeological Survey and Excavation in the Southern Isles of the Outer Hebrides'. Sheffield Academic Press, Sheffield.

Branigan, K \& Grattan, J 1998 'Coastal Assessment Survey, Barra and Vatersay'. The SCAPE Trust, St Andrews.

CFA Archaeology Ltd 2005 'Coastal Zone Assessment Survey, North Uist'. The SCAPE Trust, St Andrews.

Dawson, T 2003 'Coastal Archaeology and Erosion in Scotland'. Historic Scotland, Edinburgh.

Dawson, T 2005 Coastal Archaeology and Erosion in Scotland. Historic Scotland, Edinburgh.

Gilbertson, D; Grattan, J \& Schwenninger J-L (1996) 'A stratigraphic survey of the Holocene coastal dune and machair sequences' in D Gilbertson; M Kent \& J Grattan, The Outer Hebrides: The last 14,000 Years. Sheffield Academic Press, Sheffield.

Historic Scotland 1996 'Archaeology Procedure Paper 4: Coastal Zone Assessment Survey'. Historic Scotland, Edinburgh

Moore, H \& Wilson, G 2005 'Coastal zone assessment survey: Grimsay, Benbecula and South Uist' (http://www.scapetrust.org/pdf/suist/suist1.pdf). SCAPE Trust, St Andrews.

Parker Pearson, M \& Sharples, N 1999 Between Land and Sea: Excavations at Dun Vulan, South Uist. Sheffield Academic Press, Sheffield.

Parker Pearson M \& Smith H. Forthcoming Cille Pheadair: a Norse-period Farmstead on South Uist. Oxbow Books, Oxford.

Sharples, N (ed) 2005 A Norse Farmstead in the Outer Hebrides: Excavations at Mound 3, Bornais, South Uist. Oxbow Books, Oxford. 



\title{
The Archaeology of sand landscapes: looking for an integrated approach
}

\author{
David Griffiths \\ University of Oxford
}

Scottish Archaeological Internet Report 48, 2011 www.sair.org.uk 



\section{CONTENTS}

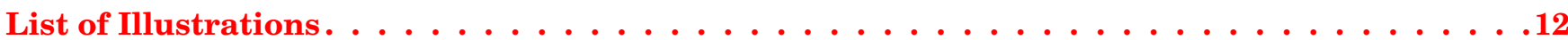

1 The Archaeology of Sand Landscapes: Looking for an Integrated Approach . . . . . . . . . 13

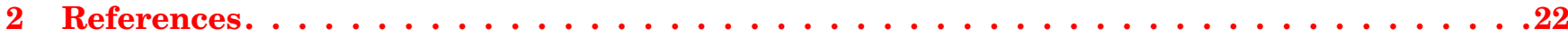




\section{LIST OF ILLUSTRATIONS}

1. Map: Bay of Skaill, Sandwick Parish, Orkney ～. . . . . . . . . . . . . . . . . 15

2. Magnetometer survey on north side of Skaill Bay, 2003-06 . . . . . . . . . . . . . . . 17

3. Mound of Snusgar: topographic survey model (viewed as from SE) . . . . . . . . . . . . . . 18

4. Magnetometer survey near Skara Brae $2003 \ldots \ldots \ldots \ldots$ 


\section{THE ARCHAEOLOGY OF SAND LANDSCAPES: LOOKING FOR AN INTEGRATED APPROACH}

The coastal dune systems and semi-stabilised machair of Scotland represent a vast but still largely unquantified archaeological and palaeoenvironmental resource. They are an inherently fragile, unstable and changing environment and therefore highly susceptible to erosion, providing a significant management dilemma for curatorial authorities. Few such landscapes, even in the wider context of Britain and Ireland, have yet been subjected to anything like a comprehensive characterisation study, encompassing prospection, sampling and investigation, resulting in well-informed selective preservation or mitigation strategies. Practical problems encountered during traditional excavation such as dune instability and deflation, deep and unstable sand overburdens and the consequent danger of breaking up stabilising ground cover and accelerating erosion, have meant that we have remained largely dependent on chance exposures to determine the extent of archaeological features and therefore of any intervention. However, increasing utility, versatility and affordability in combined prospection methods have begun to point towards new ways forward in tackling this type of landscape.

My own interest in sand landscapes was initially sparked some years ago by an aspect of my $\mathrm{PhD}$ research on Early Historic coastal trade and settlement (Griffiths 1992) which brought together a surprising number of antiquarian, and also more recent, reports of stray finds of artefacts in coastal sand dune areas in the Irish Sea Region and in Atlantic Scotland and Ireland (see also Griffiths forthcoming 2009). These vary considerably in date, detail and apparent quality, but a common factor is the presence in close proximity of ceramic, lithic or metalwork material from widely differing periods, often from the Neolithic or Bronze Age together with Early Historic or Medieval objects. Examples include the Culbin Sands, Moray (Black 1891), and Stevenston Sands, Ayrshire (Callander 1933). A further extremely important and rich site of this type is Meols, Wirral, north-west England (Hume 1863; Travis 1922; Kenna 1986; Griffiths 2001; Griffiths et al 2007). Pre-twentieth and early twentieth-century reports are characterised by little or no contextual information, concentrating exclusively, or almost exclusively, on describing the artefacts themselves.

By the mid 20th century, chance discoveries of artefacts began to be accompanied by small-scale excavation, often revealing spreads of occupation debris, hearths and middens, cultivation soils and ard-marks, and even occasionally fragments of buildings, such as at Luce Sands, Galloway (Davidson 1952, Jope 1959), and Murlough Dunes,
Dundrum, Co. Down (Collins 1952, 1959). The style of the time was to treat archaeological exposures in sand as discrete sites and to excavate them using standard terrestrial techniques - there being as yet little understanding of the effects on archaeological material of the mechanisms of post-depositional change in this type of environment. The very fact that erosion and dune deflation provided the main means of identifying deposits which were subsequently investigated, means that the associated data-capture was severely affected by in situ destruction, migration and turbation of deposits. Associations of artefact and stratigraphic context are therefore potentially suspect, and furthermore, many radiocarbon determinations, particularly from the earlier decades of this technique, are affected by growing doubts over the Marine Reservoir Effect and other distorting factors (Ascough et al 2004). Consequently, through no fault of the excavators, these interventions must generally be regarded as providing less reliable and complete a record than many contemporary interventions on 'solid ground'.

Therefore, the broad approach in the less recent past to these types of landscape could be characterised as:

- ad hoc

- reactive to erosion

- responsive to in situ exposures of visible contexts leading to small-scale rescue or salvage excavation

- often dealing with already severely compromised deposits

- focused on finds retrieval

By the 1970s, growing acknowledgement of the limitations of a site-specific approach, coupled with realisation of the potential for reconstructing past landscapes and environments, led to a broadening of approaches encompassing more systematic survey and observation, selective excavation and palaeoenvironmental sampling, combined with more sustained and balanced radiocarbon programmes. A significant example of progress in tackling the archaeology of sand landscapes is the work of Trevor Cowie and others at Torr's Warren, Luce Sands in Galloway (Cowie 1997). This landscape, characterised today by a vast, and now largely stable dune system, is one of the most archaeologically tantalising and intractable in Scotland, having produced over the decades at least 8,000 artefacts of prehistoric, Roman and Medieval date. Yet years of faithful and determined observation and collecting by a handful of devoted local archaeologists had not succeeded in establishing a coherent overall 
context for these objects, despite the occasional discovery of individual structures and burials. The work of the Central Excavation Unit in 1977-79, led by Cowie, was confined to a development area of 75 hectares within a dune landscape of over 1,200 hectares. However, the sample covered by the investigation (approximately 6.25\%) was large enough to begin to create a true landscape perspective. Machine-clearing of overburdens of up to $15 \mathrm{~m}$ in depth allowed the excavation of buried palaeosols which had been exposed in section by dune deflation and blow-outs. The erosive mechanism by which artefacts and other archaeological matter had accumulated in blow-out hollows was more clearly documented than has been the case previously in this or any similar landscape (ibid, 15). Buried palaeosols associated with archaeological material were interlaminated with layers of windblown sand; pollen analysis from dune slack area (the results of which extended back only $c 3,000$ radiocarbon years) confirmed that changes in vegetation had been very marked, showing alternating predominance of woodland and heath since the Bronze Age. The consequent interpretation was that settlement had taken place in the Neolithic and the Bronze Age, and subsequently in the Early to High Medieval periods, on stabilised agricultural soils which were separated by intervals of gradual, but ultimately extensive, aeolian sand inundation beginning in the mid to later second millennium $\mathrm{BC}$, and succeeded by another more sudden and catastrophic episode in the Later to Post-Medieval period, coinciding with the well-known effects of climatic downturn at that stage.

A further example of the growing 'landscape approach', albeit still conditioned largely by visible exposure rather than prospection-based methods, is the campaign of research mounted by Durham University at Freswick Links, Caithness, between 1979 and 1984 (Morris et al, 1995). This involved a series of sample excavations along a bay coastline badly affected by aeolian erosion, wartime disturbance, rabbit burrowing and sand quarrying, and where (as with other sites of this type), there had been a number of previous small archaeological excavations. The Freswick project included a detailed and analytical topographic survey extending $250 \mathrm{~m}$ north-south along the east-facing bay within an overall control grid, which in itself represented an advance on the piecemeal approaches taken previously. Column sampling, augering, small-scale excavation, cleaning and recording exposed sections, all provided a broad integrated stratigraphic model for the interleaved blown sand and occupation layers encountered on the links. An extensive environmental programme was put in place which added considerably to the small stock of existing knowledge about Late Norse exploitation of marine resources in northern Scotland.

The most substantial and integrated approach to sand-covered landscapes (and adjacent sand-free areas) has been the SEARCH project initiated by
Sheffield University in 1988 in the southern islands of the Western Isles. Its adequacy as a model for future approaches is discussed below. An account and bibliography of this project is provided in these proceedings (Parker Pearson et al).

One important conclusion which flows from studies at these sites, and a range of other recent fieldwork (see elsewhere below), is that humans have actively modified this type of landscape in the past. The build-ups of soil forming ancient land surfaces now buried within dune sequences are not always byproducts of periods of 'natural' landscape stability - they are evidence of the deliberate creation of stasis by the spreading of pedogenic materials. In this case, therefore, we are dealing with a relative scale of past human agency - decisions to persist with soil stabilisation or to abandon the process, are conditioned by locally specific factors and affected by varying rates of continuing erosion and wind-driven inundation by sand (the 'Bad Year Syndrome' affects these landscapes as much as any other, if not more so). Identifying the tipping-points of agricultural and settlement feasibility, and winning or losing the struggle against the sand, is a critical aspect of our search for explanations for the interrupted character of human settlement in these areas. It is therefore critical that we have an informed grasp both of the general geomorphological background and also its local specifics - so building a true multi-disciplinary landscape perspective is critical here. In dune systems, past land surfaces bearing archaeological and palaeoenvironmental information of great importance are interlaminated with aeolian deposits which have very different accumulation and erosional characteristics in terms of both materials and durability. Subsequent geomorphological changes have severely compromised the integrity of these deposits, but quantifying this is an extreme challenge to conventional reconnaissance techniques.

The approach of curatorial authorities such as Historic Scotland and English Heritage in more recent times is to recognise the need for informed management strategies based on an effective method of auditing the survival and loss of resource - and it is this need for coherent and statistically viable bodies of data from both exposed and eroded, and unexposed and intact contexts, which presents archaeologists with their current challenge. The most pressing need now is to continue to develop a suite of prospection methods which can move well beyond visual exposure as the starting point for the archaeological response. An effective means of 'seeing beneath the sand' is needed not only to find, locate, characterise and map a new realm of archaeological information currently more or less out of our reach, but also to set the state of known archaeology (including exposed traces along coastlines, records of former excavations and upstanding earthworks which have yet to be investigated) into a more comprehensive data-set covering the whole landscape under study. 


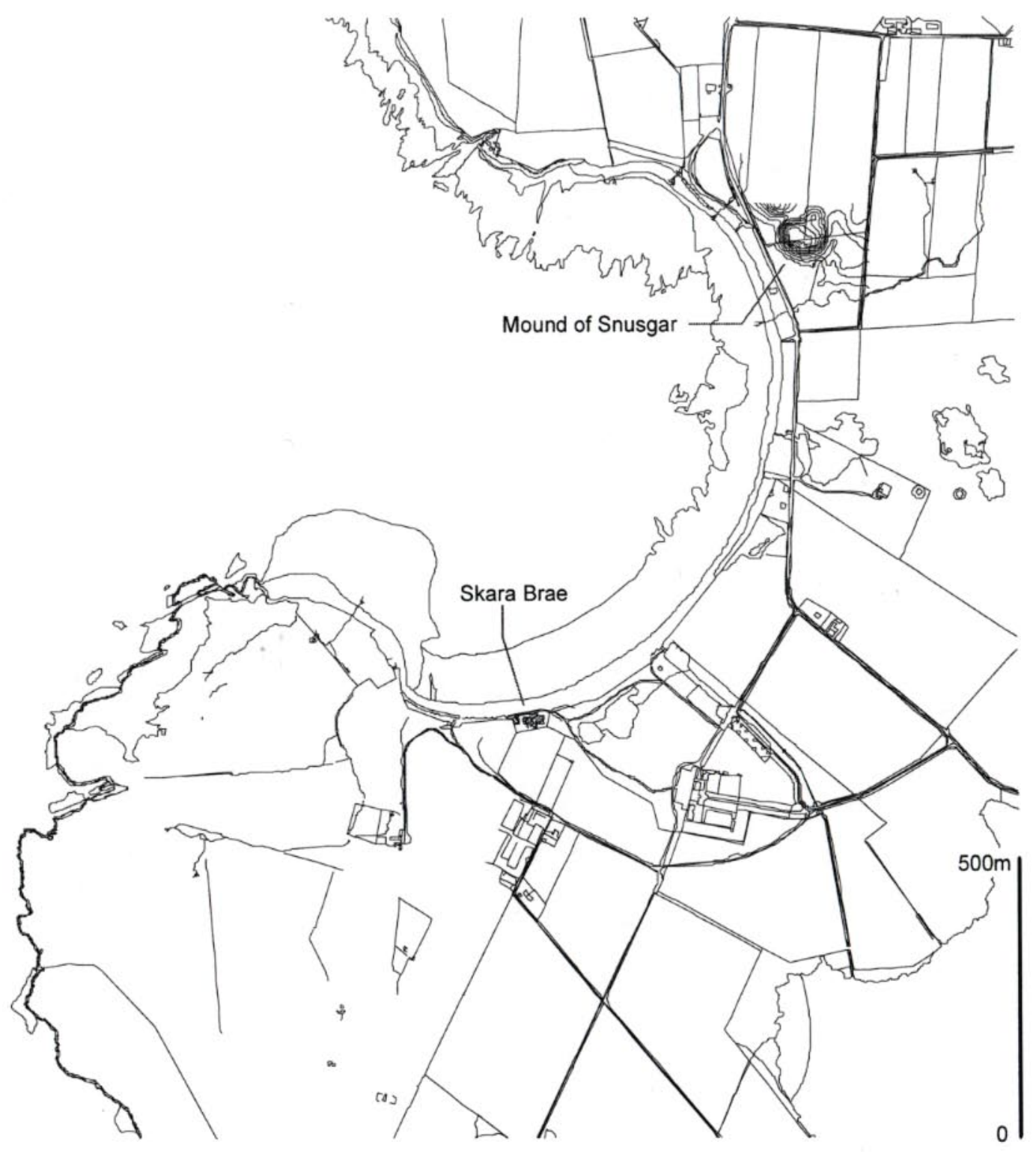

Illus 1. Map: Bay of Skaill, Sandwick Parish, Orkney

The various projects discussed below are all of direct interest to the wider question of how we build a more representative and informative sample of archaeology in aeolian areas.

A recently begun research project of my own at Birsay Bay and the Bay of Skaill, two extensive low-lying and sandy erosive openings in the Atlantic frontage of the West Mainland of Orkney, has started to build up a wider landscape perspective using integrated geophysical and topographical survey, around an archaeological landscape characterised previously by small-scale reactive excavations in the coastal erosion zone.

The choice of field research locations in Orkney was driven, apart from basic requirements such as permissions for access and likely geological feasibility for magnetic survey (afforded in this case by the predominance of the Stromness Old Red Sandstone, see Mykura 1976), by the aim to test and exceed the scope of existing archaeological data. A short but intensive programme of magnetometry survey, topographical survey and (in Birsay only) magnetic susceptibility topsoil mapping was carried out in June-July 2003 with funding from Orkney Islands Council. In 2004-08, with funding from Historic Scotland and with further support from Orkney Islands Council, the geophysical survey across the northern side of the Bay of Skaill was extended substantially, combined with ground probing radar 
(GPR) survey, and small-scale excavations at the Point of Buckquoy, Birsay, and at the 'Castle of Snusgar' on the north side of the Bay of Skaill, which tested the nature of the 2003 results in more depth and detail than geophysics can provide on its own. This project is ongoing and a recent interim report covers the details of the results of the first season (Griffiths 2006).

Birsay Bay and the Bay of Skaill are both locations of known significant archaeological potential - in the case of Skaill extending to part of the Orkney World Heritage Site (WHS) buffer zone around the designated site of Skara Brae on the south side of the bay. Yet in both cases, the current state of archaeological knowledge is highly site-specific, based on small-scale intensive excavation strategies in the past, and the ad hoc discovery of stray finds and deposits. The excavation strategy of the 1970s, whilst successful in that it produced a highquality record of the sites investigated (Ritchie 1977, Morris 1989), was essentially reactive to rapid erosion patterns and dependent on an acute 'rescue' ethos. Moreover, the area percentage of the archaeological landscape investigated in detail by this means was tiny. The predictive element which might be afforded by a more detailed insight into the archaeological potential of the landscape, within and away from the immediate erosion zone, was not readily available at the time. Two to three decades on from the hey-day of coastal rescue excavation in Orkney West Mainland, greatly enhanced techniques of prospection offer the opportunity not only to effect new and informative data (which, by concentrating on the 'gaps' between known sites, could not only find new foci but contribute to the re-evaluation of existing evidence), but to contribute to an updated and informed curatorial strategy which seeks to audit and manage the effects of coastal change, rather than merely to react to them. Testing the wider applications of landscape prospection in Orkney was also a factor; several surveys have taken place in and outwith the WHS area, but, although growing, the proportion of coverage is still lower than for other high-profile archaeological areas of Britain such as Wessex.

For the purposes of this paper, given the scope and coverage of the project so far, the Bay of Skaill is the more appropriate case-study, being a true aeolian landscape, whereas the Point of Buckquoy at Birsay (where the survey has hitherto been concentrated), although a classic eroding landscape, lacks the same extent of wind-blown accretions. The central and southern hinterland of Birsay Bay is of course another classic example of an aeolian landscape, but one which has yet to be studied in detail as part of this particular project. The Bay of Skaill, which is also an active erosion zone, is characterised by higher ground to the north and south with fresh water sources, which acted as past settlement attractors. The centre of the bay is characterised by extensive blown-sand deposits at Sand Fiold, some of which is improved land. In the centre of the low-lying bay hinterland is a group of tumuli, at least one of which was opened by Sir Joseph Banks in $c 1772$ (NMRS HY21 NW15). To the north of the bay is a scatter of discrete sites including a broch, the 'Knowe of Verron' (NMRS HY21 NW22) and an enigmatic mound or knowe known as the 'Castle of Snusgar' (NMRS HY21 NW21, NGR 2361 1960), near which was discovered the tenth-century Skaill Viking silver hoard, a chance find in 1858 brought about by a local man delving into rabbit burrows which had colonised a thick layer of sand on the flanks of the mound (Graham-Campbell 1995). Further inland to the east, on a higher zone of the Sand Fiold, vehicle movement associated with sand quarrying accidentally revealed a rock-cut pit within which was a cist grave (NMRS HY21 NW35, Dalland 1999). The wider context within the Sand Fiold of this unusual prehistoric structure has not yet been explored.

The Snusgar mound has been the focus of continuing research in 2003 and 2004 (Griffiths 2006). Snusgar is mentioned in NMRS, but is otherwise unscheduled and falls outwith the WHS buffer zone. There are even some cautionary suggestions that the mound may be a natural geomorphological feature (eg Morris 1985, 85) .The 'castle' name is probably connected to the visible remains of a stone building which was noted in 1795 (Old Statistical Account of Scotland 16, 458), standing on the north-west sector of the mound. Norse 'castles' in the form of small masonry fortifications do exist in Orkney, but there is no conclusive evidence to support the identification of one here. Certainly no in situ masonry is visible today, but a microtopographical survey (illus 3) showed a flat platform on the north-west sector of the summit with a shaped and graded slope on west and north, about where the 'castle' may have stood. Rabbit burrowing has disturbed and turbated areas of the summit and flanks. Other notable features mapped here include a north-east spur of the mound above a depression to the east where a spring is located, and a dry gully to the north-west dividing the Snusgar mound from another topographical rise, albeit a lower and less well-defined one.

Geophysical investigation in 2003 comprised approx. seven $30 \times 30 \mathrm{~m}$ grids of magnetometer survey both on and off the mound flanks and summit. The area of sandy scrub around the base of the mound proved unresponsive - presumably because any measurable deposits are masked by more than $1 \mathrm{~m}$ of aeolian sand. However, the upper part of the Snusgar mound itself proved to be a viable prospect for magnetometry survey, producing results of dense contrast, revealing it to be a highly complex, and apparently largely archaeological structure (for a detailed overview of the results, see Griffiths 2006). In 2003, some limited further reconnaissance and magnetic scanning of the area to the north-west of the Snusgar mound, on both sides of the road, suggested that these midden-type deposits may be more widespread. 


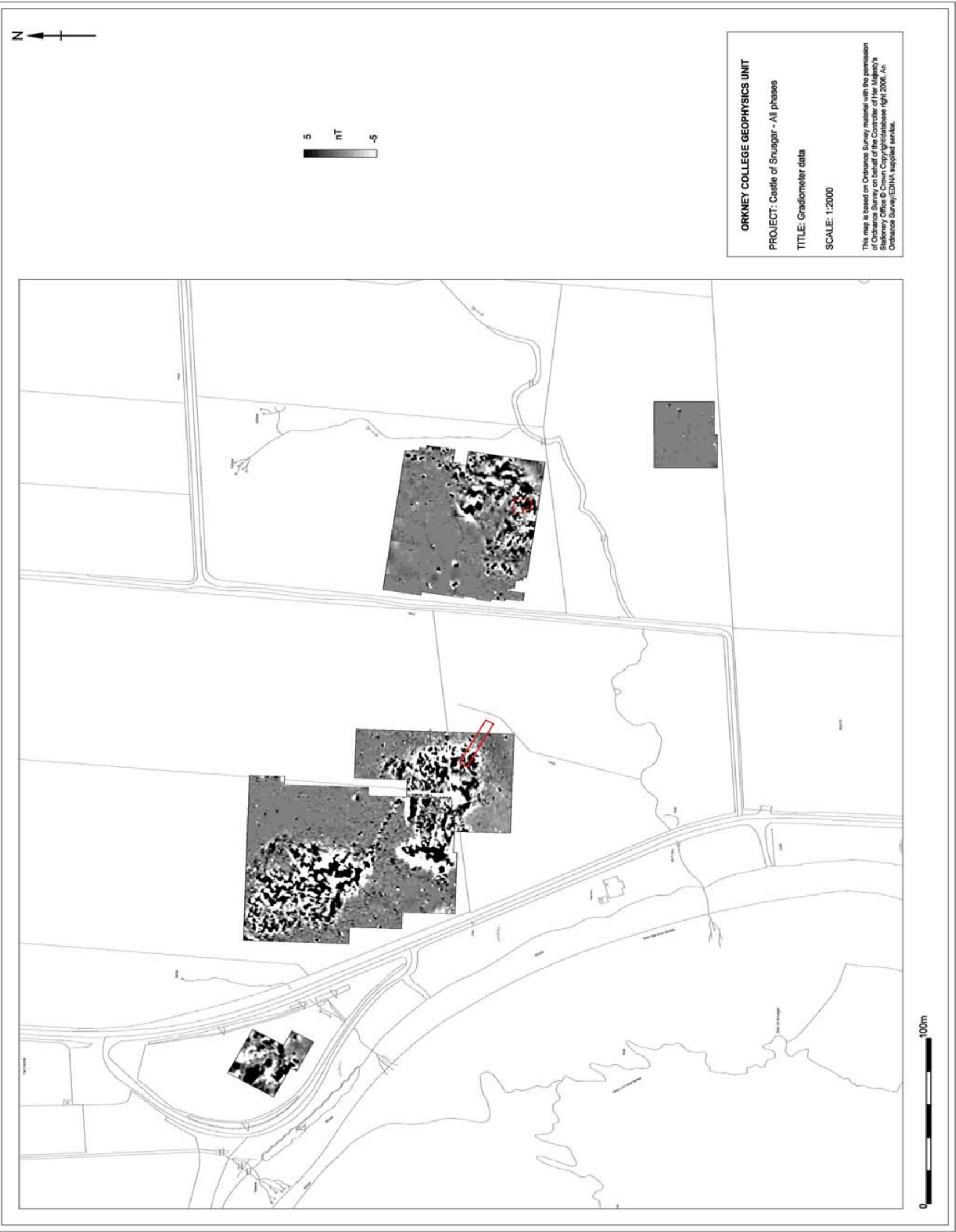

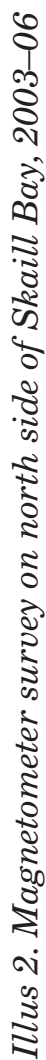




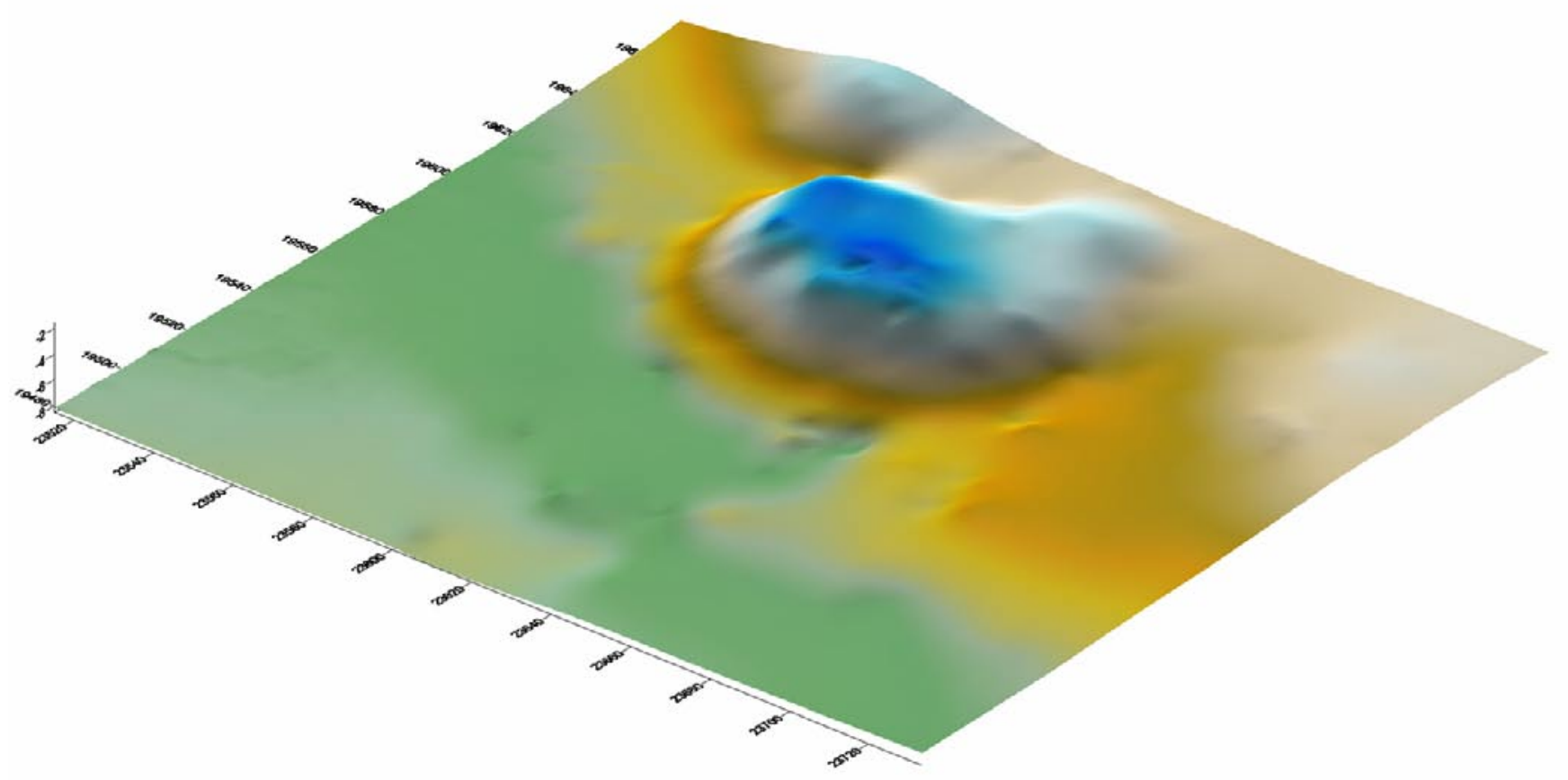

Illus 3. Mound of Snusgar: topographic survey model (viewed as from SE)

Further geophysical survey in July-August 2004 comprised resistance and magnetometry surveys carried out in conjunction with Dr Susan Ovenden, the recently appointed geophysical field officer at Orkney College/UHI. The mound of Snusgar itself, including the area of coverage of the 2003 magnetometry survey, was surveyed using a Geoscan RM15 resistance meter. This was undertaken partly in order to test the theory that the 'castle' mound was a shaped or even fortified structure, and also to provide control for the 2003 magnetometry results. Further magnetometry survey was carried out over the neighbouring mound or topographical rise which is located across a narrow dry gully to the north-west of Snusgar, and where limited augering had shown a further concentration of midden-type deposit in 2003. Two further large mounds, one yet further to the west (NGR HY 2345 1970), which is cut by the road, and one to the east of Snusgar (HY 2075 1960), were also surveyed using magnetometry. The westernmost mound, cut by the present SkaillQuoyloo road, attracted our attention because it had been the scene, when the road-cut was created in $c$ 1934 , of the reported discovery (alas going largely unrecorded) of stone structures and burials of clear archaeological interest (NMRS HY21 NW23). By contrast, the mound to the east of Snusgar, which is very badly scarred by rabbit burrowing, exposing a large eroding section across its west side, was selected as a control exercise as it was strongly suspected of being all, or largely, a sand dune (this assumption turned out to be erroneous, see below, with further investigations producing substantial archaeological features).

Work on the geophysical data is still ongoing and will be reported more fully elsewhere, but preliminary results on Snusgar itself indicated that there was a band of higher resistance partly surrounding the base of the mound on the east and south sides - the reason for which is as yet unknown. A spread of lower resistance characterised the top of the mound, but coherent hints of structures were only visible in the north-west sector of the mound, where excavation was not planned to take place in 2004. The 2004 magnetometry survey showed that the mound or rise immediately to the north-west of Snusgar is of considerable potential archaeological interest, confirming our 2003 field observation of hints of midden layers and masonry rubble exposed in rabbit holes. Very much as at Snusgar itself, a dense cluster of contrasting anomalies was mapped on this neighbouring mound. The mound further to the west produced some potential archaeological anomalies, but the survey response was compromised by high levels of later surface disturbance and litter caused by the fact that a large part of its generally flat surface has been used in recent memory for animal burials and also (unwittingly) as an unofficial tourist campsite.

Accompanying the extended geophysical campaign in summer 2004 was a three-week excavation on the north-east flank of Snusgar aimed at understanding the 2003 magnetometry results (Griffiths 2006). Firstly, beneath the sandy topsoil was evidence of relatively recent activity in the form of two $c 1 \mathrm{~m}$-deep animal burial pits (estimated to date from within the last 150 years), and a discrete spread of dense red-black burnt soil with coal inclusions, located above small and crude bowl pits. A probable explanation for the latter is kelp 
burning - which occurred widely in Orkney in the 19 th century. Secondly, below and outwith the relatively discrete imprint of these modern intrusions, the character of the upper layers of the mound began to emerge in the form of a series of peat-ash layers within stone-layered features which were laminated within thin bands of wind-blown sand. Although some of the stone features as yet lack clear definition, there was clear evidence of substantial double-faced walling running east-west across the area, which was congruent with the clearer traces evident in the north-west sector of the 2003 magnetometer plot. The peat-ash layers and associated stone features contained large quantities of well-preserved animal bone and were provisionally dated by a range of stone, bone and antler artefacts to the Early Middle Viking period (c 800-1100 AD). Further work in 2005 and 2006 showed that Viking-period material constitutes the upper part of an archaeological 'core' within the mound (Griffiths 2004-05). Midden material had been used to stabilise successive occupation and cultivation layers, which were regularly inundated by incoming wind-blown sand. This has given us a significant insight into the process of mound formation, where human intervention in building up stable and cultivable surfaces using domestic refuse produces a favourable situation in the short term. However by doing so, this activity exacerbates the problem of creating an upstanding sand-trap, which ultimately makes the situation worse in the long run by inflating the mound and its flanks with further sand accumulations.

The results from the further mound some $100 \mathrm{~m}$ to the east of Snusgar produced only a very general expectation that it might contain any archaeological potential, in the form of a generally raised magnetic signature but without any apparent structural coherence. However, a small $10 \times 5 \mathrm{~m}$ test trench was dug here in 2005 , and this, which was extended in 2006 to 2008, has revealed substantial and wellpreserved stone buildings which have been dated to the Viking/Norse period (see www.conted.ox.ac.uk/ research/birsay-skaill). These had been abandoned and filled up with wind-blown sand to a depth of $1-1.5 \mathrm{~m}$, which explains why the magnetometer had registered a general spread of potential here but had been unable to filter out the structural pattern later revealed by excavation from the local background.

Skara Brae, at the southernmost point of the bay's circumference, was discovered in 1850 after marine erosion of aeolian sand deposits which had built up over the site in prehistory. The Neolithic 'village' (perhaps more accurately described as a 'tell'), which was largely exposed and cleared of overburden under the archaeological supervision of V Gordon Childe in 1929-30 (Childe 1931), and is now partly reconstructed and in guardianship, was previously deeply buried in a combination of archaeological and aeolian sand horizons within an upstanding mound (itself now all but gone from view, but still commemorated of course by the 'brae' name). Another large mound some $100 \mathrm{~m}$ to the west is currently undergoing severe erosion (Morris 1985). Half or more of this mound has now gone, leaving only a landward portion behind a fullheight semi-vertical erosive section which is visible facing the bay, in which are exposed layers of stone masonry and middens interleaved with deep sand accretions (perhaps, one imagines, bearing some similarity to the appearance of Skara Brae $c 150$ years ago).

Consent to carry out survey within the Skara Brae section of the Orkney WHS buffer zone was obtained, but targeted prospection was also deployed on a wider basis in an attempt to build a more comprehensive landscape overview for the bay. Within such a large area, a survey target zone comparable to the more coherent Buckquoy Peninsula did not immediately suggest itself, so work began by targeting known locations of archaeological potential and exploring their environs. A geophysical survey had been conducted here in 1973 by A Clark and A Bartlett of the Ancient Monuments Laboratory, in the field immediately to the south-west of Skara Brae. Their survey, from which an unpublished stack-trace plot remains on file in the Sites and Monuments Record (SMR) at Orkney Archaeological Trust, was inconclusive, but did show a very pronounced linear anomaly running WSW from Skara Brae. This proved to be an igneous dyke apparently running beneath the southern edge of Skara Brae. Whilst obviously counterproductive to magnetic reconnaissance, the presence of this feature is not without archaeological interest in such close proximity to a major Neolithic site.

The southern $30 \times 30 \mathrm{~m}$ grid in the survey closest to Skara Brae did show some hints of stone archaeological features, but these were partly masked by extensive ferrous metal contamination and modern drainage installations (this area is very close to Skaill House Farm, and the low cliff-tops and dunes to the west of Skara Brae are also scattered with bits of fishing equipment, fencing and parts of old sheds). However, the mound to the west did show more promising results. A Viking burial was found here in 1888 and a cist grave in 1994 (James 1999, $771 \mathrm{ff})$. The grey-scale plot shows a reasonable indication of the extent and shape of the southern part of the mound, and there are hints of discrete secondary structures remaining in its periphery, which would accord with the previous finds of burials. The 2003 Skara Brae Magnetometer Survey has since been superseded by a much more extensive survey carried out by Orkney College Geophysics Unit on behalf of Historic Scotland and the WHS management programme.

In the right conditions and as far as possible free of relatively recent ferrous contamination from fishing and barbed-wire fencing, and spreads of kelpburning detritus (which often limits its potential in 


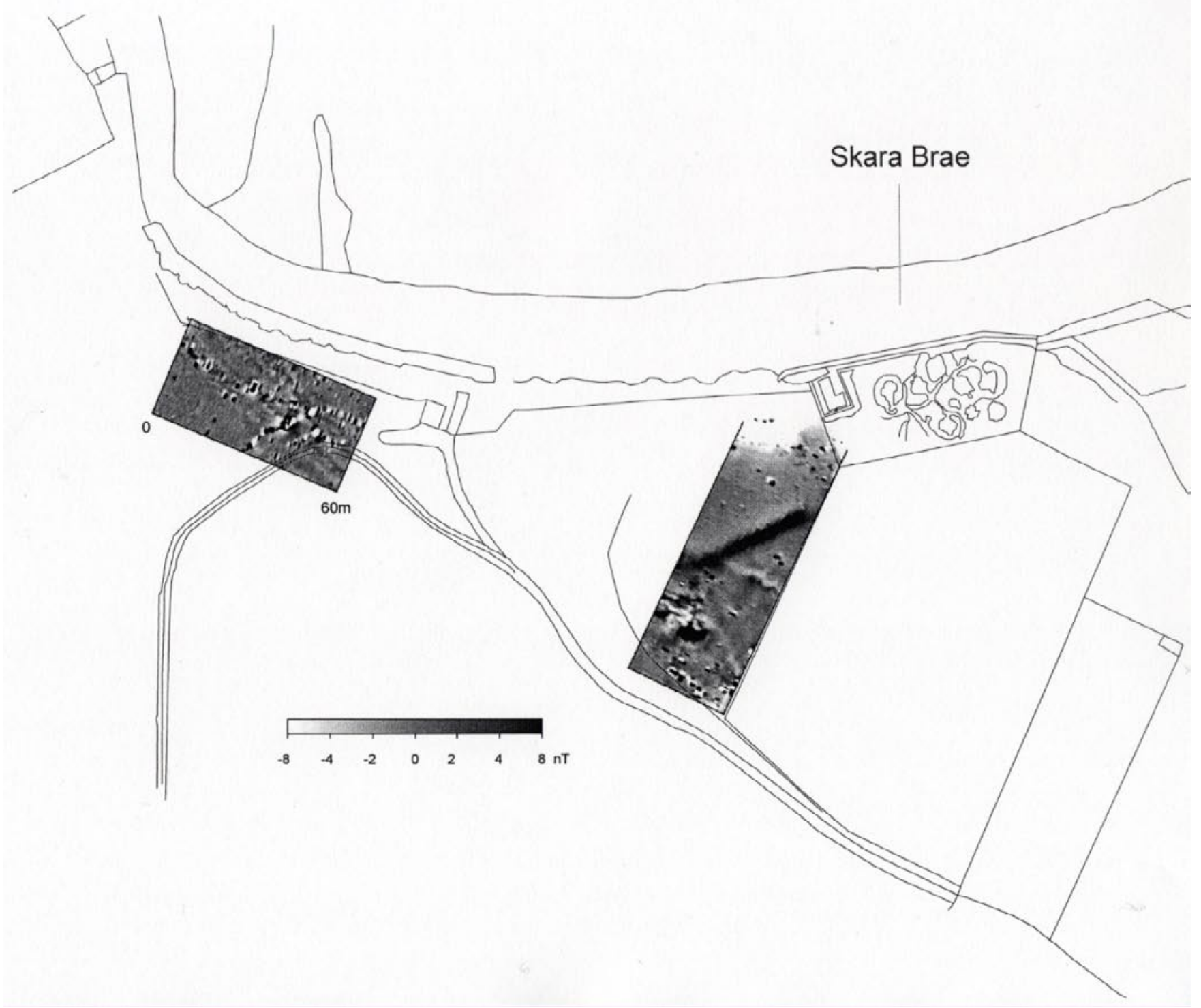

Illus 4. Magnetometer survey of Bay of Skaill, near Skara Brae, 2003

coastal margins), conventional fluxgate magnetometry can work wonders in up to $1 \mathrm{~m}$ of blown sand. This is demonstrated by an example from Harlyn Bay, Cornwall, which has now been ground-truthed in the sense that it was fully excavated for a pipeline - revealing beneath the sand extant Medieval ridge and furrow overlying Iron Age round houses; here, magnetic susceptibility topsoil mapping might have worked in probe form but the $100 \mathrm{~mm}$ surface coil is too shallow to reach the buried palaeosols (Oxford Archaeotechnics, see http://dialspace.dial.pipex. com/town/terrace/ld36/grad.htm). One way forward might be the Geonics EM31 Electrical Conductivity system (www.geonics.com), used to some effect in desert sites in the Middle East (such as the National Museums of Scotland Saqqara Project in Egypt - see www.nms.ac.uk/royal/saqqara), which pen- etrates up to $6 \mathrm{~m}$ deep - and is easy and quick to use when combined with GPS. This helps us to realise a need for a faster and more extensive prospection technique which could more effectively translate into a three-dimensional digital terrain model.

Current work therefore shows the potential, but also the limitations of techniques of conventional magnetometer survey coupled with topsoil magnetic susceptibility mapping and topographical survey. This is very good for targeting surface exposures and settlement mounds, but where sand depth reaches over $c 1 \mathrm{~m}$, its coverage becomes more patchy and difficult to interpret, leading to a loss of ability to model a coherent landscape sample. A sustainable methodology for modelling and ground-truthing both the visible and subsurface deposits is needed, which combines the 
potential for visualising archaeological deposits both in demonstrable areas of potential and also in the 'gaps' between. Moreover, this must be one which in the case of sand areas does not in itself increase dune instability.

For an integrated approach, therefore, the way forward would include a combination of the following methodological objectives:

- building rapid and cost-effective means of modelling the archaeological and palaeoenvironmental resource through survey and GIS.
- developing sustainable methodologies for ground-truthing and dating the resource.

- providing an enhanced and more widespread multi-disciplinary understanding of ongoing geomorphological processes and potential for sudden change.

- auditing preservation and loss of deposits.

The proceedings published below provide a resource of experience, results and references which are intended to promote the four objectives as outlined above. 


\section{REFERENCES}

Ascough, P L; Cook, G T; Dugmore, A J; Barber, J; Higney, E; Scott E M 2004 'Holocene Variations in the Scottish Marine Radiocarbon Reservoir Effect', Radiocarbon 46, 611-620.

Black, G F 1891 'Report on the Archaeological Examination of the Culbin Sands, Elginshire', Proc Soc Antiq Scot 25, 490-95.

Callander, J G 1933 'A Collection of Prehistoric Relics from the Stevenston Sands, Ayrshire and Other Objects in the National Museum', Proc Soc Antiq Scot 67, 26-34.

Childe, V G 1931 Skara Brae, A Pictish Village in Orkney, Kegan Paul, London.

Clark, A; Bartlett, A 1973 Geophysical Survey at Skara Brae, AM Laboratory, unpub. Ms.

Collins, A E P 1952 'Excavations in the Sandhills at Dundrum, Co. Down 1950-51', Ulster Journal of Archaeology 15, 2-26.

Collins, A E P 1959 'Further Investigations in the Dundrum Sandhills', Ulster Journal of Archaeology $22,5-20$.

Cowie, T G et al 1997 'Torrs Warren, Luce Sands, Galloway: A Report on Archaeological and Palaeoecological Investigations Undertaken in 1977 and 1979', Transactions of the Dumfriesshire and Galloway Natural History and Antiquarian Society 71, 11-105.

Dalland, M 1999 'Sand Fiold: The Excavation of an Exceptional Cist in Orkney', Proceedings of the Prehistoric Society 65, 373-413.

Davidson, J M 1952 'Report on the Discoveries at Glenluce Sands, Wigtownshire', Proc Soc Antiq Scot 86, 43-69.

Graham-Campbell, J A 1995 The Viking Age Gold and Silver of Scotland, $A D$ 850-1100. National Museum of Scotland, Edinburgh.

Griffiths, D W 1992 'Anglo-Saxon England and the Irish Sea Region, $\mathrm{AD} 800-1100$ 'Unpub. $\mathrm{PhD}$ thesis, Dept of Archaeology, University of Durham.

Griffiths, D 2001 Great Sites: Meols, British Archaeology Issue 62, Dec 2001, 20-25.

Griffiths, D 2004-05 'Birsay-Skaill Landscape Archaeology Project', Discovery and Excavation in Scotland, New Series 5 (2004-05), 94-5.

Griffiths, D 2006 'Birsay and Skaill Orkney, Landscape Survey 2003-04', in Jones, R; Sharpe, L (eds) 2006, 'Going over Old Ground, Perspectives on Archaeological Geophysical and Geochemical Survey in Scotland', British Archaeological Reports, British Series 416, Oxford, 213-24.

Griffiths, D; Philpott, R; Egan, G 2007 'Meols: The Archaeology of the North Wirral Coast', Oxford University School of Archaeology Monograph Series 68.
Griffiths, D 2008 'Birsay-Skail landscape archaeology project, Orkney', www.conted.ox.ac. $\mathrm{uk} / \mathrm{research} /$ projects/birsay-skaill.

Griffiths, D forthcoming 2009 'The Sand Dune Sites, Evidence for Pre-Viking trade' in GrahamCampbell, J A; Ryan, M (eds) Ireland and Britain in the Pre-Viking period, Proceedings of a Symposium held at the British Academy, October 2005, British Academy/Royal Irish Academy.

Hume, A 1863 Ancient Meols, or Some Account of the Antiquities found on the Sea Coast of Cheshire, London.

James, H 1999 'Excavations of a Medieval Cemetery at Skaill House, and a Cist in the Bay of Skaill, Sandwick, Orkney', Proc Soc Antiq Scot 129, 753-77.

Jones, R; Sharpe, L (eds) 2006 'Going over Old Ground, Perspectives on Archaeological Geophysical and Geochemical Survey in Scotland', British Archaeological Reports, British Series 416, Oxford.

Jope, E M 1966 An Archaeological Survey of County Down, HMSO, Belfast.

Jope, E M; Jope, H M; Stewart, I H; Thompson, J D A 1959 'A hoard of fifteenth-century coins from Glenluce sand dunes and their context', Medieval Archaeology 3, 259-79.

Kenna, R J B 1986 'The Flandrian Sequence of North Wirral (NW England)', Geological Journal 21, $1-27$.

Morris, C D 1985 'Skaill, Sandwick, Orkney: Preliminary Investigations of a Mound-site near Skara Brae', Glasgow Archaeological Journal $12,82-92$.

Morris, C D 1989 'The Birsay Bay Project, Volume 1', Department of Archaeology Monograph Series 1, University of Durham.

Morris, C D; Batey, C E; Rackham, J 1995 Freswick Links, Caithness: Excavation and Survey of Norse Settlement, Historic Scotland/NABO/ Highland Archaeology Monograph No. 1.

Mykura, W 1976 British Regional Geology, Orkney and Shetland, HMSO, Edinburgh.

Old Statistical Account 1791-99 The Statistical Account of Scotland, drawn up from the communications of the ministers of the different parishes 15 (Orkney), Edinburgh.

Parker Pearson, M; Mulville, J; Sharples, N; Smith, H 2008 'Archaeological remains on Uist's machair: threats and potential'. SAIR 48, Society of Antiquaries of Scotland, Edinburgh.

Ritchie, A 1977 'Excavation of Pictish and Vikingage farmsteads at Buckquoy, Orkney', Proc Soc Antiq Scot 108, 174-227. 
Travis, W G 1922 'On Peaty Bands in the Wallasey Sandhills', Proceedings of the Liverpool Geological Society 13, 207-214. 



\section{North Atlantic climate change and Late Holocene windstorm activity in the Outer Hebrides, Scotland}

Sue Dawson

Geography, School of Social and Environmental Sciences, University of Dundee, Perth Road, Dundee, DD1 4HN

Alastair G Dawson

Aberdeen Institute of Coastal Science and Management, School of Geosciences, St Mary's, University of Aberdeen, Aberdeen, AB24 3UF

$$
\text { Jason T Jordan }
$$

Department of Geography, Environment and Disaster Management, George Eliot Building, Coventry University, Priory Street, Coventry, CV1 5FB 



\section{CONTENTS}

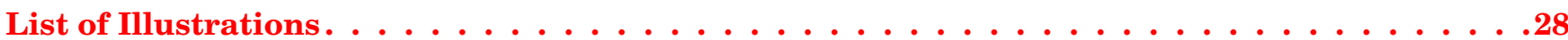

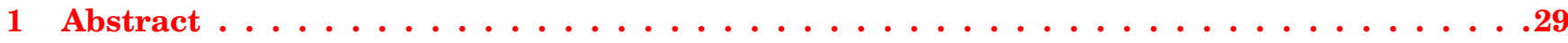

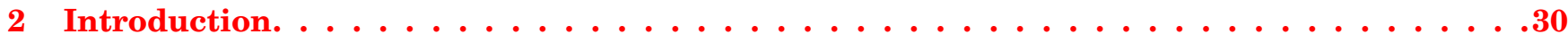

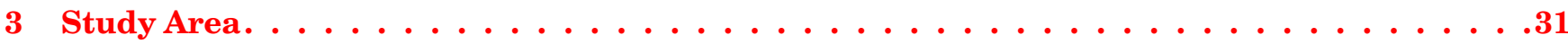

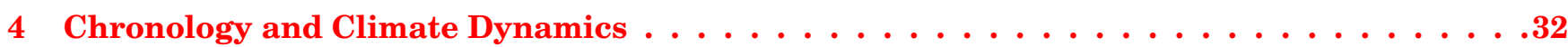

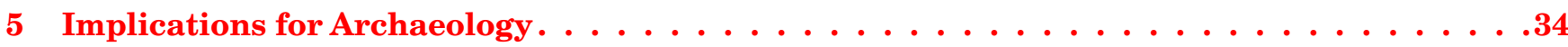

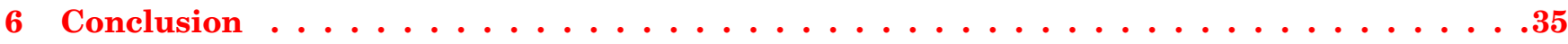

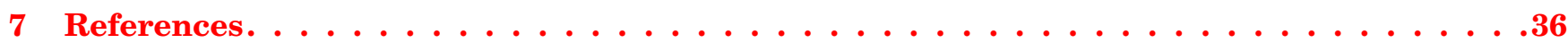




\section{LIST OF ILLUSTRATIONS}

1

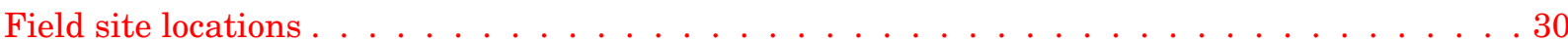

Concentrations of $\mathrm{Na}+$ (ppb) at GISP2 drill site, central Greenland, AD 987-1987;

and 2-sigma calibrated radiocarbon dates showing the start of windstorm sedimentation

at study sites (after Meeker \& Mayewski 2002) . . . . . . . . . . . . . . . . . . . 32

$3 \quad$ Graph showing the number of weeks with ice around Iceland, for 20-year intervals

from AD 860-1935 (after Koch 1937) . . . . . . . . . . . . . . . . . . . . . . . . . . . . 33 


\section{ABSTRACT}

Lithostratigraphical and biostratigraphical investigation of marshes adjacent to coastal dune sequences in the Scottish Outer Hebrides show inland-tapering sand units enclosed within organic sediments. The sand sheets are considered to have been deposited by past windstorm activity, while radiometric dating appears to indicate deposition during the last 2000 years except for the well-known period of Medieval warmth that is here considered to have occurred between $c \mathrm{AD} 600$ and 1400. It is argued that the episodes of sand-blow indicated by the deposits may reflect periods of increased cyclogenesis in the North Atlantic associated with increased sea-ice cover, an increase in the thermal gradient associated with the polar atmospheric and oceanic fronts as well as colder air temperatures. It is also noted that the diminished North Atlantic winter storminess during Medieval times was broadly coincident with the expansion of Viking culture. 


\section{INTRODUCTION}

In recent years reconstructions of Late Holocene climate variability of the North Atlantic region have been enhanced considerably as a result of Greenland ice core research. In particular, our knowledge of changes in North Atlantic storminess has been transformed as a result of the published chronology of $\mathrm{Na}+$ (sea salt) concentration changes from the GISP2 drill site (Meeker \& Mayewski 2002). Annual changes in sea-salt concentration at GISP2 calculated for the last 1,400 years have been interpreted as a regional signal of North Atlantic winter storminess change. The sea-salt concentration time series is resolved to an annual scale and thus provides a high-precision long-term record of storminess change that can be compared with other records of change (e.g. meteorological time-series).

In this paper, we explore in more detail the results of Dawson et al (2004) that described Late Holocene coastal windstorm deposits from the Scottish Outer Hebrides. Radiocarbon dating of peat deposits enclosing the sand units were used to construct a local chronology of Late Holocene windstorm events that were, in turn, used to test the Meeker and Mayewski (2002) hypothesis that an increase in winter storminess took place after $c$ AD 1400-20 during the so-called Little Ice Age (LIA), this having been preceded by a period of negligible storm activity during the Medieval Warm Period (MWP).

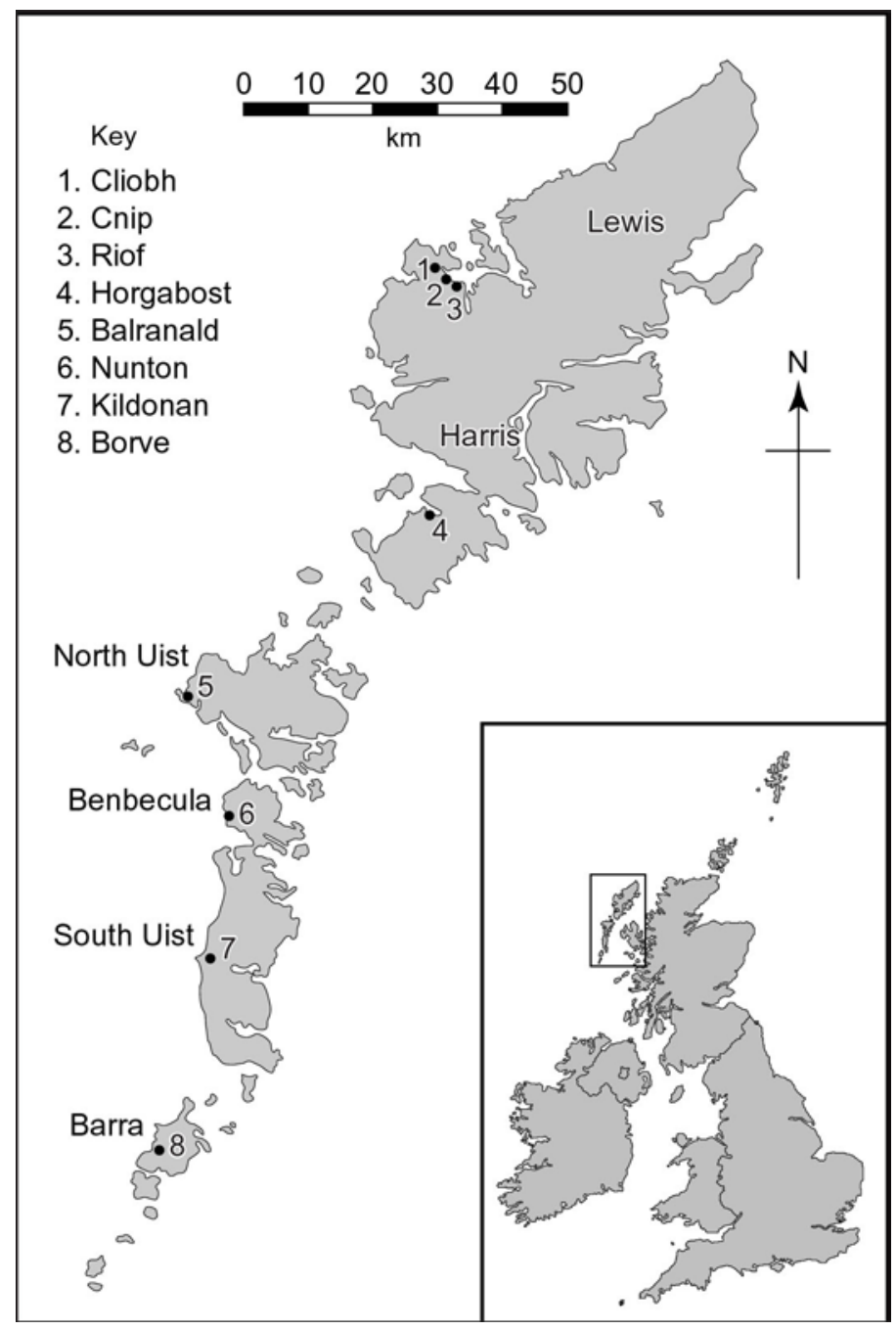

Illus 1 Field site locations, Scottish Outer Hebrides 


\section{STUDY AREA}

The Outer Hebrides island chain (illus 1) extends from broadly north to south across a latitudinal range of $56^{\circ} \mathrm{N}-58^{\circ} \mathrm{N}$, thus occupying an area presently influenced by the North Atlantic storm track. The islands are characterised by Lewisian gneiss bedrock that rises to heights locally in excess of $500 \mathrm{~m}$, but along the Atlantic margin the bedrock is characterised by sub-horizontal rock surfaces located a few metres above sea level. These are mantled by largely stabilised dune systems consisting of coastal dunes to seaward and a gently sloping surface to landward, where the system ends within peat areas, rocky outcrops and many small lochs. The sand-dominated landscape is locally known as machair, a Gaelic word that describes a low-lying, grass-dominated coastal plain composed of calcareous sand, with a calcium carbonate content up to c 80\% (Ritchie \& Whittington 1994). Notwithstanding the apparent uniformity of the machair surface, the occurrence of organic horizons within dune sediment exposures implies a complex evolutionary history.

Studies of sediment exposures and of foreshore peat deposits have been undertaken by several researchers, including Ritchie (1979, 1985), Ritchie and Whittington (1994) and Gilbertson et al (1996; 1999) that, in turn, have led to the development of a model of machair evolution. The model is based on the concept that during the Holocene rise in sea level, glacially-derived sands from offshore were mobilised and mixed with comminuted shell debris. This material was reworked into coastal ridges and moved onshore over pre-existing lacustrine and organic deposits (Ritchie 1985).

The complex nature of machair evolution was demonstrated by research undertaken in the Uists by Ritchie and Whittington (1994), who showed that locally variable stratigraphic sequences had resulted from non-synchronous sand-blow (windstorm) events. Ritchie and Whittington (1994) demonstrated that the earliest sands represent 'overlapping landform suites' which, through long-term erosion, outcrop today in the present intertidal zone. They argued that the onset of sand movement was non-synchronous across the Outer Hebrides and had been strongly influenced by local coastal configuration. They maintained that the culmination of the Holocene rise in sea level resulted in a reduction in offshore sediment supply to the coast. Since relative sea level reached its approximation position $c 2000$ years ago, it was argued that coastal sediment transport during recent millennia has been principally associated with a recycling of pre-existing coastal sediments and a possible degradation of pre-existing coastal dunes and machair. 


\section{CHRONOLOGY AND CLIMATE DYNAMICS}

Dawson et al (2004) described dated storm events for seven sites across the Outer Hebrides that exhibit distinctive age clustering. Only three of the dated storm horizons exhibit standard errors that place the sediments within parts of the MWP time interval. By contrast, the majority of the uppermost dated horizons appear to have been deposited after $c$ AD 1300. The stratigraphical evidence indicates that a sustained period of machair and dune development in which shelly sands encroached inland ended between the end of the MWP and perhaps as recently as 200 years ago.

It is tempting to develop a hypothesis in which the frequency of storm events is related to past episodes of climate change, normally described in terms of former air temperature characteristics, with greater storm frequencies during periods of cold (e.g. the LIA), and periods of reduced storminess during episodes of warmth (e.g. the MWP). Such explanations, however, are fraught with difficulty since the westerly winds associated with severe North Atlantic cyclones (storms) are normally associated with higher than average winter temperatures. Equally, it can be argued that the coldest episodes of the LIA may have been associated with significantly reduced storminess owing to the expansion of the polar anticyclone and a southward movement of the polar atmospheric and oceanic fronts across the North Atlantic (Lamb 1995).

Meeker and Mayewski (2002) provided the most

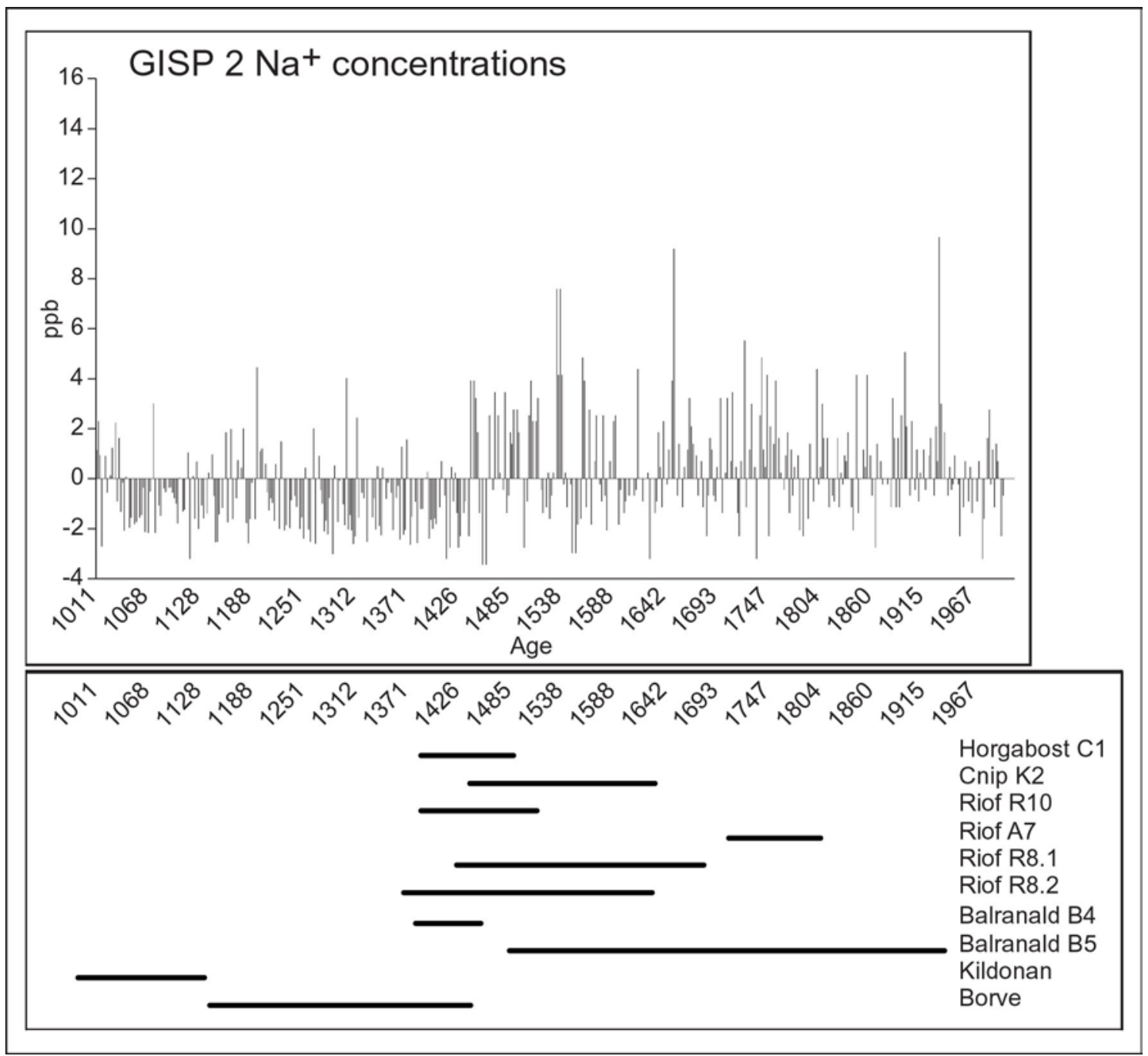

Illus 2 Top: concentrations of Na+ (ppb) at GISP2 drill site, central Greenland, AD 987-1987 shown as departures from the long-term average (after Meeker \& Mayewski 2002). Bottom: 2-sigma calibrated radiocarbon dates showing the start of windstorm sedimentation at study sites (see also illus 1). 


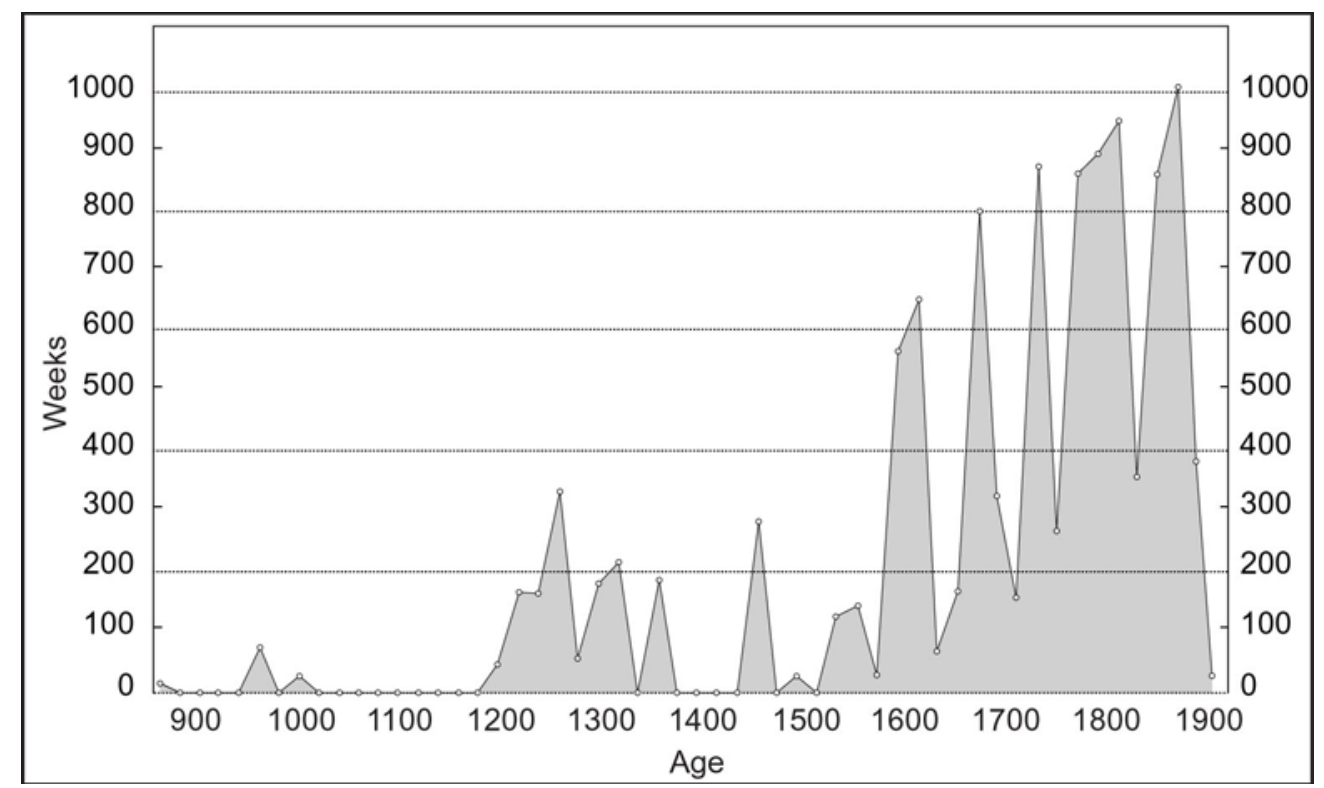

Illus 3 Graph showing the number of weeks with ice around Iceland, for 20-year intervals from AD 860-1935 (based on Koch 1937).

comprehensive record of North Atlantic storminess for the last $c 1,400$ years based on measurements of sea-salt $(\mathrm{Na}+)$ concentrations in the GISP2 Greenland ice core (illus 2). Their measurements show that reduced storminess was a feature of the MWP that lasted between $c$ AD 600 and 1400. They detected a marked increase in storminess frequency (increased $\mathrm{Na}+$ concentration) that commenced at this time and observed that this 'state' of increased storminess has lasted until the present.

These observations should also be considered within the context of the classic research of Lamb (1979), who argued that the cold conditions of the LIA were associated with an increased meridional (north-south) thermal gradient across the North Atlantic that, in turn, led both to a southward displacement of the North Atlantic storm track (the polar atmospheric front) and of polar waters (the southern limit of the polar oceanographic front). Considered together, the results of Lamb (1979) and Meeker and Mayewski (2002) point to an increase in winter storminess across the British Isles after $c$ AD 1400-20 and preceded by diminished winter storminess during the MWP. It is argued here that such increases in the thermal gradient in the North Atlantic atmosphere provide a simple explanation for the greater frequency of windstorm sediment deposition and machair formation post-AD 1400 (and possibly also for the time interval studied here prior to the MWP).

The dated sand units are plotted on the same timescale to illustrate the clustering of the dates during the LIA time period. This pattern of stormi- ness increase also coincides with an increase in Icelandic sea ice cover that commenced during the late $13^{\text {th }}$ century (Koch 1937) (illus 3).

Stratigraphical studies from sites along the Atlantic margin of Scotland and Ireland, as well as from the North Sea region, provide support for the chronology of sand mobilisation described here. Gilbertson et al (1999) also describe late Holocene phases of sand movement in the Outer Hebrides $c$ 200-600 years ago ( $c$ AD 1400-1800), c 1,300-1,700 years ago ( $c \mathrm{AD} 300-700$ ) and $c 3,300-3,800$ years ago (c 1800-1300BC) based on luminescence dating of calcareous machair sands. Orford et al (2000) concluded that the majority of coastal dune systems in eastern England were produced during the LIA. Similarly, Delaney \& Devoy (1995) noted that in western Ireland remobilisation of sand across back barrier lagoonal sites took place over the last $c 400$ years.

It could be argued that some of the dated windstorm events in the Outer Hebrides may be related to anthropogenic activity related to overpopulation, animal grazing pressures and the harvesting of marram grass for domestic purposes during the 18th and 19th centuries (cf Angus 1994, 1997). Although such processes were undoubtedly important in machair destabilisation and aeolian sediment transport, we maintain here that the increase in North Atlantic storminess that commenced at $c \mathrm{AD} 1400-20$ and has continued until the present was the key factor accounting for the ages of the windstorm deposits described from the sites examined within this paper. 


\section{IMPLICATIONS FOR ARCHAEOLOGY}

A key implication for archaeological research is that North Atlantic winter climate may have changed dramatically between the MWP and LIA. For example, during the MWP a diminished thermal gradient in the North Atlantic may have resulted in a substantial decrease in cyclogenesis that most probably also coincided with a marked decrease in sea ice extent and a significant decrease in winter rainfall. By contrast, a marked increase in winter storminess coupled with an increase in rainfall took place during the LIA. Considered together, these factors imply that it is misleading simply to consider the principal difference between the MWP and the LIA as a marked change in temperature. The real difference between the two time intervals is a radical difference in the atmospheric circulation of the northern hemisphere. During the time interval between $c$ AD 600 and 1400, North Atlantic winters were rarely characterised by extreme storminess and high rainfall, while sea ice cover was never as extensive as it was during parts of the LIA. The ice core data point to the most benign conditions of the MWP as having occurred during the 9th and 10th centuries AD, and it may not be a coincidence that this time interval coincided with the first European settlements of Greenland and Iceland. Similarly, the disappearance of Viking civilisation in Greenland during the first decades of the 15th century AD coincides not only with a dramatic increase in winter storminess (a phenomenon not witnessed by earlier Viking generations), but also by a dramatic increase in the extent of sea ice that may have greatly hindered navigation. Whatever the ages of specific coastal sediment units at Viking sites in the Outer Isles, the Vikings themselves are likely to have developed styles of land use that were unsuited to the stormy and wet winters that accompanied the onset of the LIA.

In respect of coastal change, it may be useful to envisage many coastal Viking settlements as having been buried as a result of LIA windstorm activity and sand drift. Thus, it may have been the case that many Viking settlements in the Outer Hebrides may have evolved in landscapes where coastal dunes were much rarer features than they are at present. It is recognised, however, that many areas of machair in the Outer Hebrides may already have been in existence prior to the MWP, having owed their origins to windstorm activity during earlier intervals of stormy conditions during the Holocene. 


\section{CONCLUSION}

This paper has considered the age and origin of sand sediments enclosed within organic deposits at sites within the Scottish Outer Hebrides and has also discussed patterns of North Atlantic climate change for the last $c 2,000$ years. It is suggested that a chronology of past storminess is recorded in the coastal sand dune sequences along the Atlantic coastline of the Outer Hebrides. The morphological and stratigraphical evidence indicates a concentration of windstorm activity during the LIA with a major reduction in sand drift during Medieval times between $c \mathrm{AD} 600$ and 1400. The geological data indicate that windstorm deposition may have taken place during periods of climate deterioration and seaice expansion across the northern North Atlantic, associated with an increased thermal gradient favourable for increased production of winter storms. Dated inferred sand-drift episodes across the Atlantic seaboard of north-west Europe show a broad synchronicity with increased sand mobilisation in eastern England, south-west Ireland and the Outer Hebrides, implying a regional response to a change in northern hemisphere atmospheric circulation (Lamb 1995; Gilbertson et al 1999; Wintle et al 1998; Wilson et al 2001). 


\section{REFERENCES}

Angus, S 1994 'The conservation importance of machair systems of the Scottish Islands, with particular reference to the Outer Hebrides', in J M Baxter \& M B Usher (eds) The Islands of Scotland: A Living Marine Heritage 95-120. HMSO, Edinburgh.

Angus, S 1997 The Outer Hebrides: The Shaping of the Islands. The White Horse Press, Harris.

Dawson, S; Smith, D E; Jordan, J \& Dawson AG 2004 'Late Holocene coastal sand movements in the Outer Hebrides, NW Scotland', Marine Geology 210, 281-306.

Delaney, C \& Devoy, R 1995 'Evidence from sites in western Ireland of late Holocene changes in coastal environments', Marine Geology 124, 273-87.

Gilbertson, D D; Kemp, R A \& Grattan, J (eds) 1996 The Outer Hebrides: The Last 14,000 Years. Sheffield Environmental and Archaeological Research Campaign in the Hebrides (SEARCH) Vol. 2, 275. Sheffield Academic Press, Sheffield.

Gilbertson, D D; Schwenninger, J L; Kemp, R A \& Rhodes, E J 1999 'Sand-drift and soil formation along an exposed North Atlantic coastline: 14,000 years of diverse geomorphological, climatic and human impacts', Journal of Archaeological Science 26, 439-69.

Hammer, C; Mayewski, P A; Peel, D \& Stuiver, M (eds) 1997 'Greenland summit ice cores: Greenland ice sheet project 2 and Greenland ice core project', Journal of Geophysical Research $102,26,315-886$.

Koch, L 1937 'The East Greenland ice', Meddelelser om Grønland, Ud givne af Kommissionen for Videnskabelige Undersøgelser I Grønland, Bd $130, \mathrm{Nr} 3$.

Lamb, H H 1971 Climate, History and the Modern World. Methuen Press, London.

Lamb, H H 1979 'Climatic variations and changes in the wind and ocean circulation: the Little
Ice Age in the North-east Atlantic', Quaternary Research 11, 1-20.

Lamb, H H 1995 Climate, History and the Modern World. $2^{\text {nd }}$ Edition, Routledge, London.

Meeker, L D \& Mayewski, P A 2002 'A 1,400-year high resolution record of atmospheric circulation over the North Atlantic and Asia', The Holocene $12,257-66$.

Orford, J D; Wilson, P; Wintle, A G; Knight, J \& Braley, S 2000 'Holocene coastal dune initiation in Northumberland and Norfolk, eastern UK: climate and sea-level changes as possible forcing agents for dune initiation', in I. Shennan \& J. Andrews (eds) Holocene Land-Ocean Interaction and Environmental Change around the North Sea, 197-217. Geological Society Special Publications 166, London.

Ritchie, W 1979 'Machair chronology and development in the Uists and adjacent islands', Proceedings of the Royal Society of Edinburgh 77, 107-122.

Ritchie, W 1985 'Inter-tidal and sub-tidal organic deposits and sea level changes in the Uists, Outer Hebrides', Scottish Journal of Geology 21, 161-76.

Ritchie, W \& Whittington, G 1994 'Non-synchronous aeolian sand movements in the Uists: the evidence of the intertidal organic and sand deposits at Cladach Mor, North Uist', Scottish Geographical Magazine 110, 40-46.

Wilson, P; Orford, J D; Knight, J; Bradley, S M \& Wintle, A G 2001 'Late Holocene (post-4,000 years BP) coastal development in Northumberland, north-east England', The Holocene 11, 215-29.

Wintle, A G; Clarke, M L; Musson, F M; Orford, J D \& Devoy, R J N 1998 'Luminescence dating of recent dune formation on Inch Spit, Dingle Bay, south-west Ireland', The Holocene 8, 331-39. 


\title{
Characterising archaeology in machair
}

\author{
John Barber
}

AOC Archaeology Group

Scottish Archaeological Internet Report 48, 2011 www.sair.org.uk 



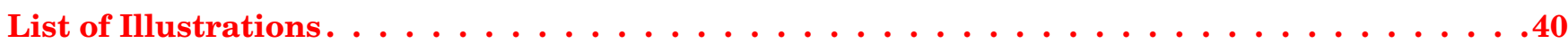

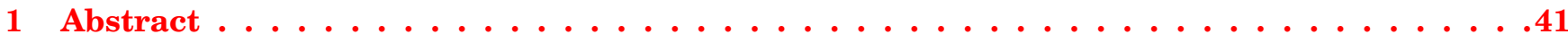

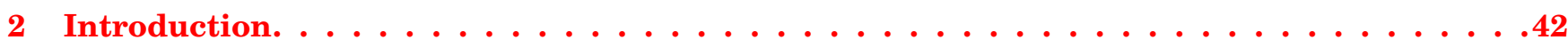

3 Distinguishing 'Archaeology' from 'Not Archaeology' . . . . . . . . . . . . . . . . . .44

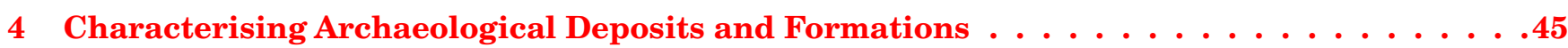

4.1 Dynamism and sensitivity: processes of whole-site formation . . . . . . . . . . . . . . 45

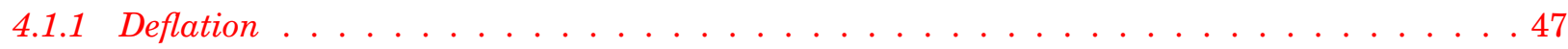

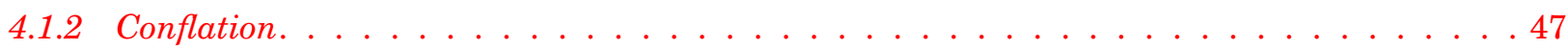

4.1 .3 Diachronic deposits. . . . . . . . . . . . . . . . . . . 47

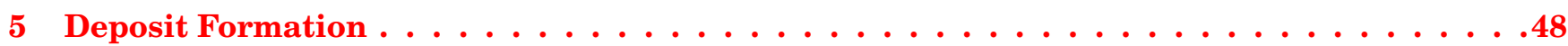

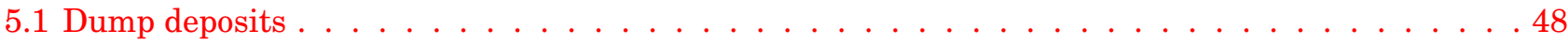

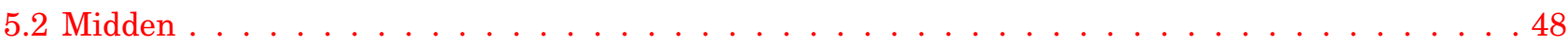

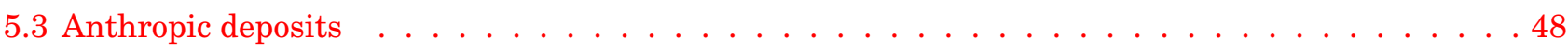

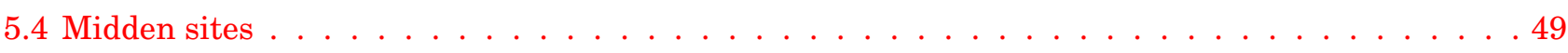

5.5 Cultivated deposits $\ldots \ldots \ldots \ldots \ldots \ldots \ldots \ldots$

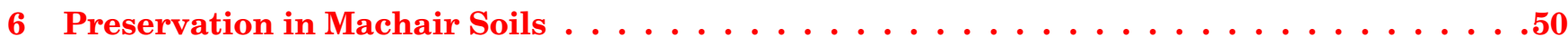

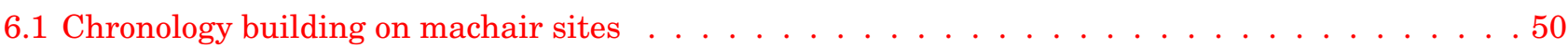

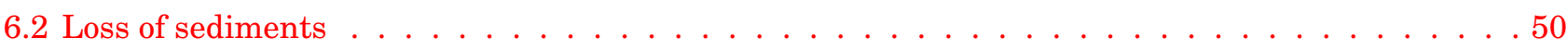

6.3 Practical problems in the use of radiocarbon dating on machair sites $\ldots \ldots \ldots$

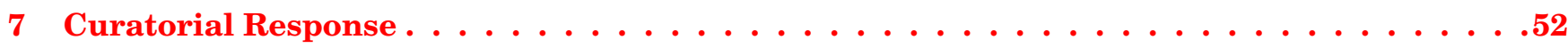

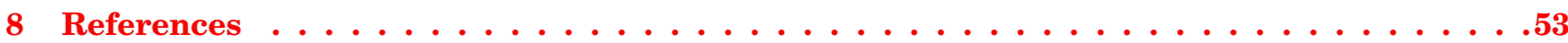




\section{LIST OF ILLUSTRATIONS}

$1 \quad$ Models of machair evolution (after Ritchie 1979) . . . . . . . . . . . . . . . . . 43

2 a, b, c Plates showing development of settlement-related deposits. . . . . . . . . . . . . . . . . 45

3

The domed structure of the site at Baleshare, with cross-section. . . . . . . . . . . . . . . . 46 


\section{$1 \quad$ ABSTRACT}

This paper deals with methodological issues involved in excavating in the machair, shell-sand systems of the Outer Hebrides and the West Coast of Scotland. The machair system is characterised by high rates of change, driven by Aeolian forces, interspersed with which human settlement intermittently occupied sites and altered the depositional regime, only in turn to have its deposits altered by subsequent human and natural processes. Characterisation of the sites and their contained deposits requires an understanding of the processes by which both anthropic and natural deposits were formed. Dating the sites and deposits requires an understanding of the dynamics of the relationship between the natural environment and the role humanity played in modifying and being modified by natural processes. Many of the richest deposits are diachronic and traditional chronology building can lead to misleading results. Rather, the focus must be on understanding and dating the sedimentary sequence and then intercalating the sequence of human activities into that depositional chronology. The almost universal availability of radiometrically datable organic materials is vitiated by the difficulties they pose for dating, and careful selection from taphonomically sound contexts is a sine qua non. The west coast machair sites are probably the richest, if also the most challenging sites in Scotland. In the aggregate, especially in the Hebrides, they represent a cultural landscape of outstanding cultural value. Their treatment by curators falls short of what they require and merit, and in a period of rapidly rising sea levels time is not on our side. More could be done and more must be done to salvage what we can from these wonderful archaeological monuments. 


\section{INTRODUCTION}

I have taken the term 'Aeolian archaeology' in the conference title to refer to Scottish west coast, shellsand, machair sites, simply because I know a little about these sites. How transferrable my comments may be to mineral-sand sites is for the reader to judge, although my observation of sites like St Boniface and Tuquoy suggests that such sites have much in common with their west-coast cousins, particularly in terms of the formation processes involved. That said, there are also some important differences between them, the machair sands having a uniformly high $\mathrm{pH}$, with associated excellent preservation of bone, for example, while mineral sands can be quite acidic and have poor preservation conditions for bone and the other calcium-based materials and for metalwork.

I use the term 'machair systemics' to describe the study of the forces, materials and processes involved in the creation, modification and destruction of machair sites and of sites within machairs. The systemics of machair formation in Scotland have been studied by Ritchie, and illus 1 is drawn from his work (Ritchie 1979). The entire machair is a system, and aspects of that natural system were also discussed during this conference. Human intervention in the machair system presents an excellent example of what Butzer (1982) described in his book of the same name as 'archaeology as human ecology'. Machair is a prime human ecological niche; it is ecotonal, between terrestrial and marine ecosystems and has positive value in its own right, especially for agriculture. The machair system is many orders of magnitude greater in all respects than the scale of cumulative human intervention in it, and it is quite impossible to understand the latter without first grasping something of the former.

Examination of the long history of human engagements with the machair landscapes has identified a pronounced human capacity to accelerate or impede the rates of natural change and perhaps from time to time also to reverse the direction of change. The substrate of the machair is shell sand. Machair systemics suggest that the natural forces, materials and processes that create, modify and destroy machair are central also to the formation, modification and destruction of archaeological sites within machair. Those forces are in continuous operation; the system is meta-stable or, at the very least, its apparent stability is a dynamic equilibrium maintained over periods probably not much longer than single human lifetimes. The principal dynamic force is the wind, while the principal static source of resistance to that force is water, particularly ground water, and the mean annual level of the water table is the determining factor in the formation of the absolutely level machair plains which give the system its name (machair means 'plain' in Gaelic). 
$1 \mathrm{~A} \&$ B
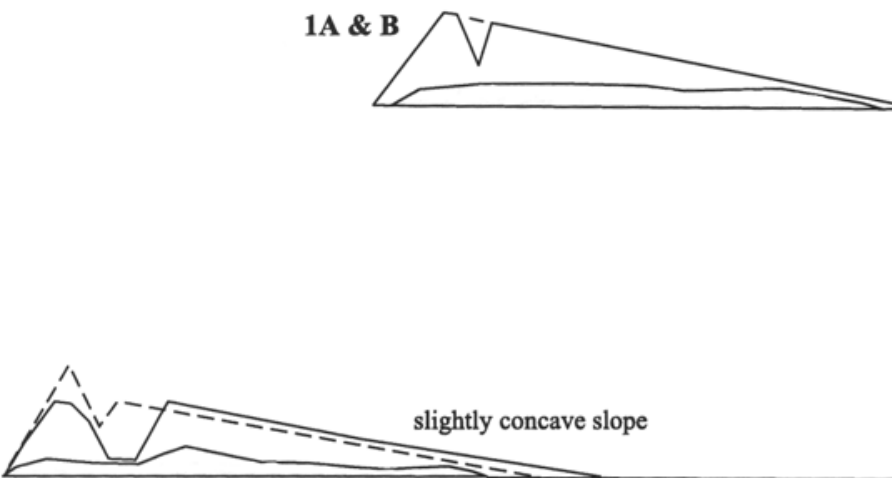

2A

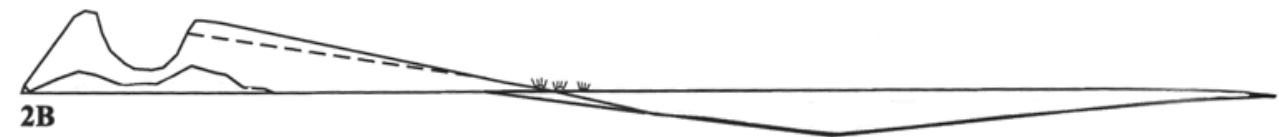

loch draining by seepage
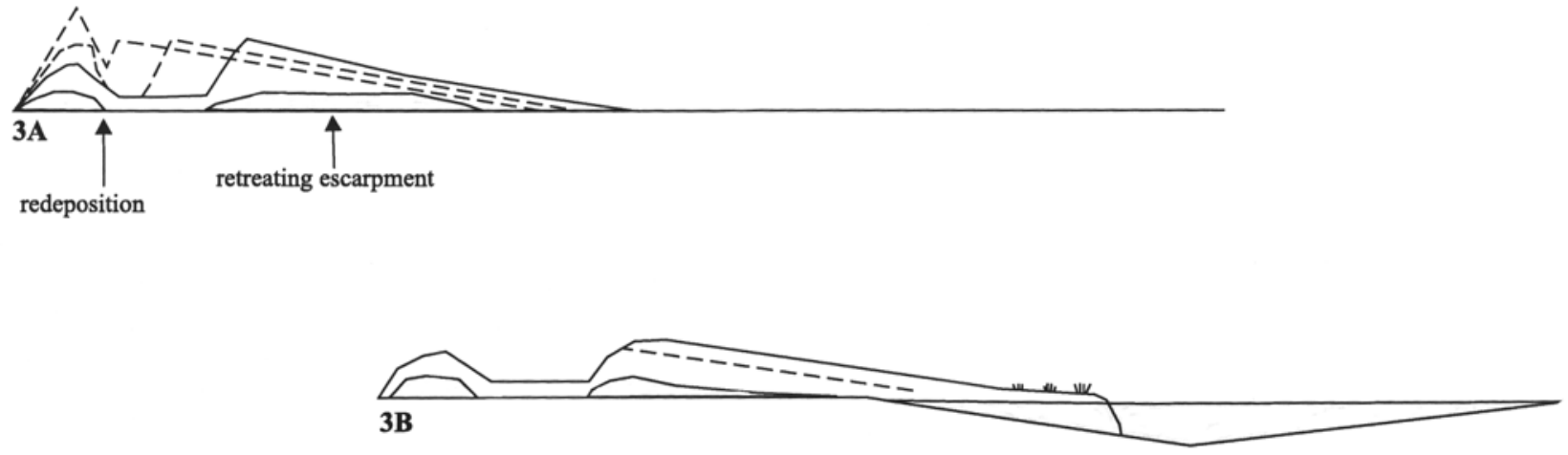

flat machair slow growth over marsh
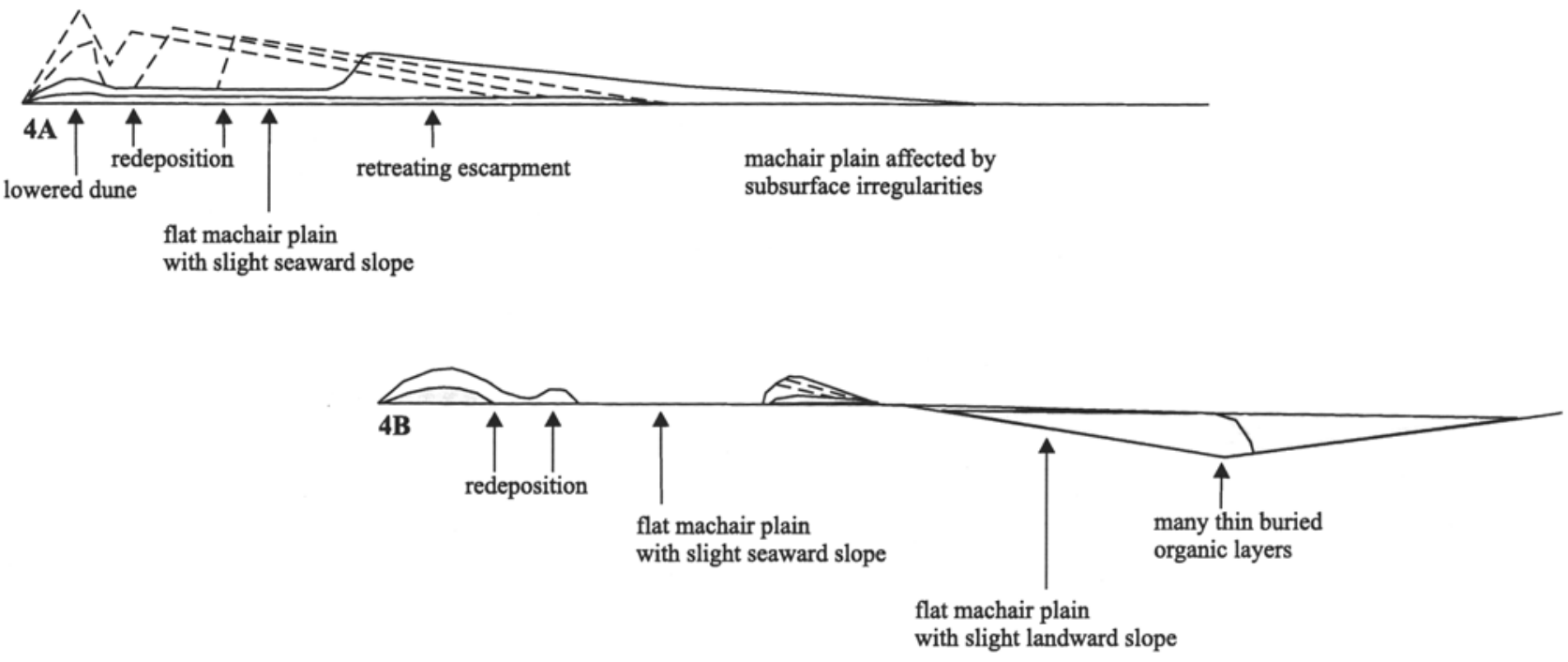

Illus 1 Models of machair evolution (after Ritchie 1979). 


\section{DISTINGUISHING 'ARCHAEOLOGY’ FROM 'NOT ARCHAEOLOGY'}

As with the loess soils of the North European Plains, the shell sands of the machair system are placed in situ by wind alone. Thus, even the merest pebble within machair deposits must have been introduced. At one level then, characterising archaeology in machair is easy: anything that is not shell sand was brought onto the machair. Seabirds do deposit some shells on the machair surface and grazing animals and some carnivores (including otters) deposit dung on the machair, and perhaps the remains of their meals, but these contributions are few and widely dispersed. The probability that any given non-sand entity is anthropic in origin is very high and if there is more than a handful of material, that probability mounts to certainty. Thus, characterising archaeology as distinct from 'not-archaeology' on the machair really is straightforward. Characterising archaeological deposits, in contra-distinction to each other, requires some consideration of how human activities meshed with machair ecosystems to result in anthropic formation processes and anthropic deposits. 


\section{CHARACTERISING ARCHAEOLOGICAL DEPOSITS AND FORMATIONS}

We have already noted that the formation process in machairs is dominated by the wind-powered distribution or redistribution of comminuted shells. Deposits associated with settlement are often wet or damp and retain moisture because of their clay (or clay-like) composition. These include midden material, decayed vegetable matter, faecal matter, animal dung, peat used as fuel and as bedding, decayed thatch, etc. These deposits resist movement themselves and provide a 'sticky' surface onto which mobile sand particles can adhere. Thus, anthropic deposits tend to accumulate within machairs and to include or subsume shell-sand deposits.

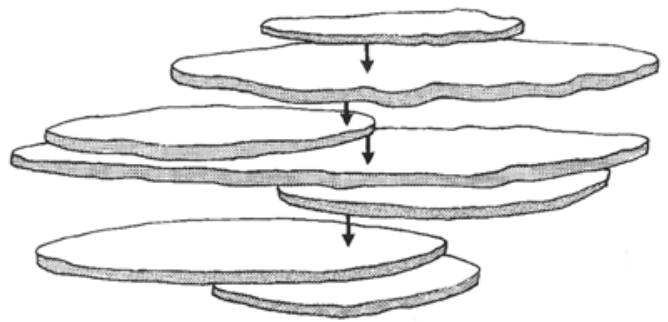

a
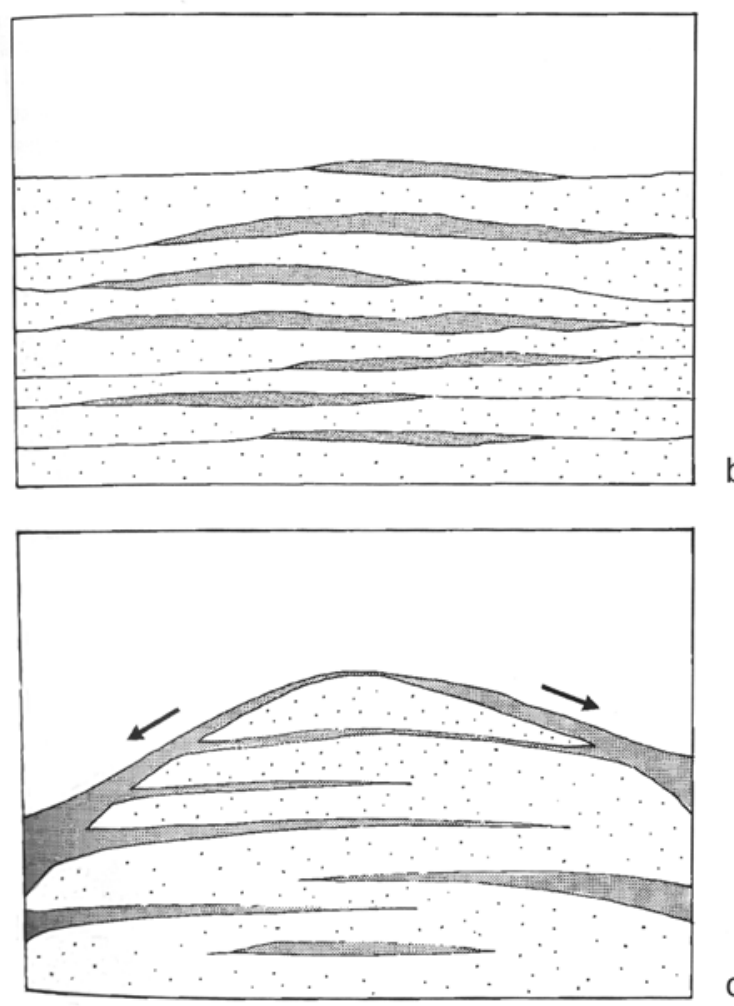

C

Illus $2 a, b, c \quad$ Plates of settlement-related deposits (a) are laid down in a continuously accumulating wind-blown sand matrix (b); subsequently, deflation of the matrix produces a domed mound covered by a conflation deposit (c).

\subsection{DYNAMISM AND SENSITIVITY: PROCESSES OF WHOLE- SITE FORMATION}

It is almost always impossible to relate anthropic site deposits to their contemporaneous machair landscapes or to contemporaneous natural machair deposits. The formation of a typical machair site is predicated on the use by humans of a particular location over time and it does not matter whether the occupation was continuous or intermittent. Let us envisage a situation in which sand is being continuously deposited at the particular point in a machair system at which human settlement is in progress. It is reasonable to assume that, over time, the extent and the foci of human settlement would have varied. Thus, the superimposed deposits would not fit exactly over each other in the deepening natural shell sand but instead would resemble an untidy pile of pancakes. If the settlement is intermittent or if the intensity of settlement (as represented in the volumes of detritus accumulating on-site) varies, and assuming that the machair continues to form while this settlement is in use, we would arrive at the situation modelled in illus 2a. In section these would appear as represented in illus 2b. However, the real-world situation is typified by that represented in illus $2 \mathrm{c}$. The sites are in general dome-shaped (illus 3), the upper surface of the dome being a more or less continuous layer, apparently comprising an archaeological sediment. This covering layer often merges into the edges of the more or less horizontal layers of the site. It is not possible for this situation to arise naturally. The covering layer cannot be contemporaneous with the succession of deposits and yet this is apparently implied by the way it touches most or all of them. If, however, we imagine that the shell-sand matrix in which the site's deposits accumulated was blown away in some past storm or during some period of erosion of the machair, we can begin to understand the gross morphology of these sites. Initial removal of the surrounding sand would have exposed the succession of layers in the margins of the site and the wet material in these layers would have resisted further erosion, to greater or lesser extent. Grass cover would eventually have stabilised the site and a new A-horizon would have formed over the whole of the site, creating an apparently continuous layer but one that would incorporate materials from all of the periods represented in the sediments of the site exposed around its margins (illus 2c). It may also include material from layers that have been completely removed by aeolian erosion, the more dense materials simply dropping down the profile as the softer sands were blown away. 

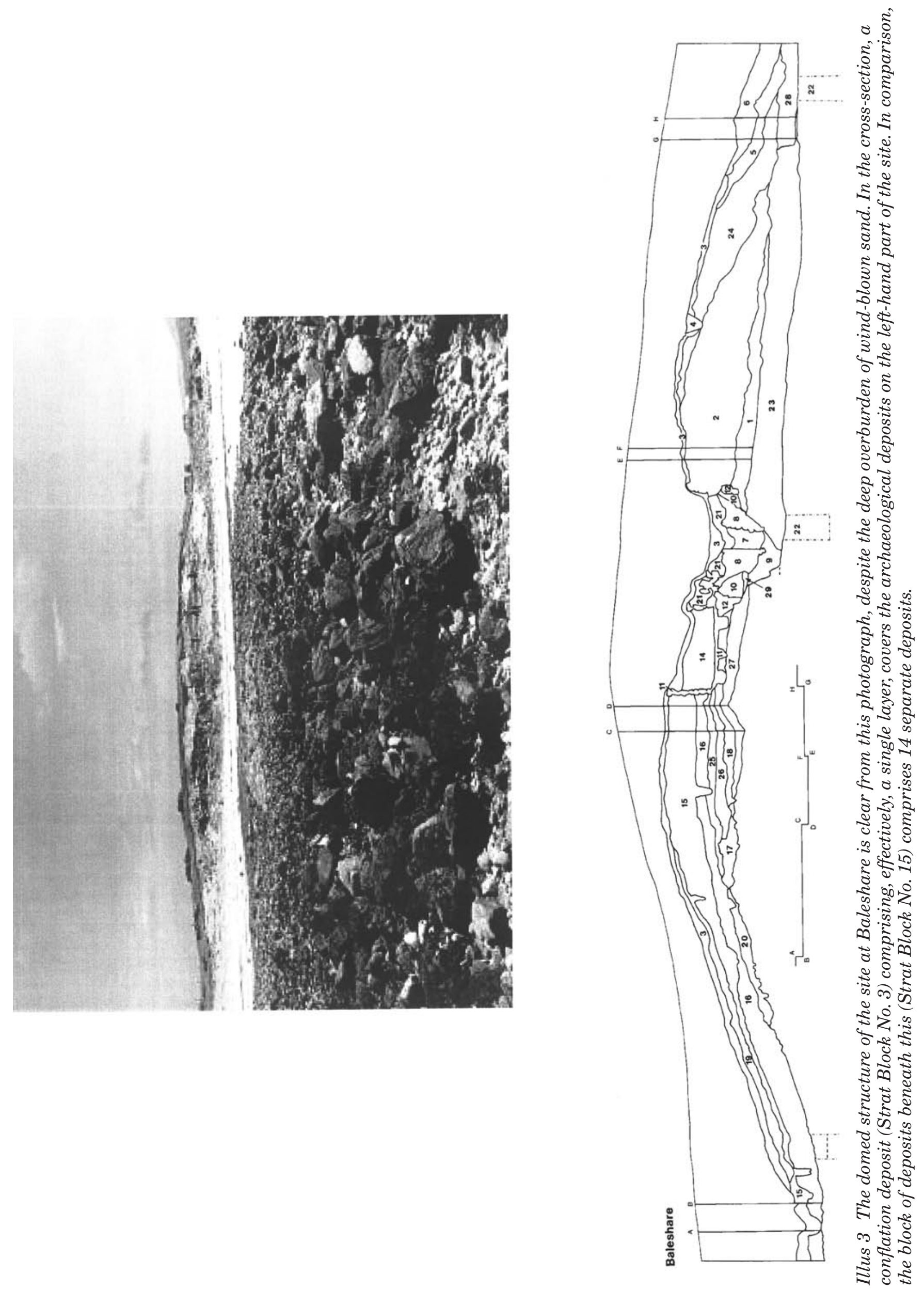
The processes of aeolian erosion and of the formation of deposits as a direct result of this purely natural process contribute to and sometimes confuse site formation in machair. The processes involved are set out here to introduce and define some terms of more general use.

\subsubsection{Deflation}

The process of deflation means the removal of sand by the force of the wind alone. Used as an adjective, the term can refer to the resultant landforms, for example 'deflation hollow' or 'deflation deposits'.

\subsubsection{Conflation}

Following the removal by wind (that is, deflation) of sandy deposits, the anthropic component of these deposits, for example bone, shell, pottery and so on and, in the context of machair sites, including stone also, does not blow away but comes to rest on some arbitrary surface, forming a deflation deposit. The resulting spread of materials may include remains of different origins and dates and at South Glendale, for example, includes Beaker, Iron Age and Medieval pottery (Barber 2003). The spread of materials can become incorporated into a new deposit, either by inundation in a fresh deposit of wind-blown sand or as a result of incorporation by bioturbation, in the deposit on whose surface they have come to rest. In either event, the resulting deposit is known as a 'conflation deposit'.

Stone structures that have been exposed by the landward progression of steep-sided erosion hollows tend to collapse into more or less amorphous piles of stone. However, where the eroding stone structure is revealed in an area from which sand is being removed over an extensive horizontal surface, the gross morphology of the structure may survive deflation.

\subsubsection{Diachronic deposits}

The sediments of a typical machair site contain deflation deposits that once lay on stabilisation horizons and that may, or may not, have become incorporated in conflation deposits. Both deflation and conflation deposits are diachronic. They are commonly the richest deposits on these sites but their assemblages are palimpsests and potentially misleading. Best practice requires that radiocarbon submissions from machair deposits should contain evidence that the deposits are neither deflation nor conflation deposits, otherwise the dates resulting are likely to prove misleading, especially if the chronology building for the site follows the traditional pattern of dating 'keynote' events rather than trying to establish a date-and-duration framework for the depositional sequence. On more extensive sites, like the lower Bronze Age field system at Baleshare (Barber 2003, 44) conflation may be harder to see because the exposures over which we typically observe them are too small. But the likelihood is that these large exposures are all diachronic since their morphology (extensive horizontal spreads) and heterogeneity imply formation by deflation, probably to some then-current water table. 


\section{DEPOSIT FORMATION}

Separate deposits build up into sites and some understanding of these deposits and their formation processes should guide our understanding of the sites themselves.

\subsection{DUMP DEPOSITS AND DUMPED DEPOSITS}

Dumped deposits are characterised by their clear boundaries and usually by the low volume of the individual contributions. They will have been formed in discrete packages, such as could be carried on or in a shovel or basket or, perhaps, wheelbarrow or cart. Dumped deposits need not contain any anthropic materials but often do so in considerable quantity. In the aggregate, a contiguous set of dumped deposits constitute a dump deposit. Dump deposits usually display large-scale heterogeneity coupled with smallscale homogeneity, that is, while the single dumped deposits may be quite homogeneous, there can be considerable diversity amongst the individual contributions making up one dump deposit. Needham \& Spence (1997) and McOmish (1996) emphasise intentionality as an important consideration in the definition of dumps and the categorisation of dumping activities. Intentionality can be confidently attributed to the removal of material from its original source. The act of gathering it together and moving it to its find-location (archaeological context) is a necessary precondition for the deposit's formation and cannot be other than deliberate. However, it is difficult to demonstrate intentionality in its disposal. Was its final resting place selected as a conscious act of human will? Structured deposition, a heavily overworked concept, presumably results in deposits for which, it is argued, their final resting place was not only selected as a conscious act of human will, but was selected to the conscious exclusion of all other places, in the enactment of some form of ritual (see Hill 1995 for discussion). The identification of structured deposits relies on an interpretation that cannot be verified in the contents of the deposit alone, and thus it should probably not be used as a primary descriptor of deposits. Rather, it should be identified explicitly as an interpretation (or a conclusion) arising from specific observations of particular material remains in specific contexts.

\subsection{MIDDEN}

The term 'midden', of Scandinavian origin, is composed of the elements møg (muck) and dynge (heap) and simply means 'muck heap' or 'dung heap' $(O E D)$. In the late nineteenth century it came to be used as an abbreviation for 'kitchen midden'. The latter term was a useful archaeological descriptor but the archaeological abuse of the term 'midden' has devalued it and caused some confusion (see Needham \& Spence 1997; and McOmish 1996 for useful discussions). Here the term is reserved strictly for deposits that are interpreted as accumulations of refuse intended for reuse as manure. A midden may contain dumped deposits and incorporate midden-site deposits.

The terminology used in the description of 'middens' and the deposits they contain is fraught with difficulty. Michael Schiffer (1987), more than any other archaeological writer, has provided a relatively clear account of deposit formation. Implicit to his exegesis is the interplay of natural and anthropic processes in deposit formation. This interplay merits consideration in dealing with machair deposits which occur in a spectrum of proportions of natural to anthropic. Deposits of machair sand with minor anthropic inclusions lie at one end, while dumped deposits of purely anthropic material with only minor amounts of machair sand lie at the other. In my publication of work in the Hebrides (Barber 2003), I used terms like 'midden-site' deposits to name certain deposits formed on the types of sites that were then called 'middens', and so on. Prompted by one of our editors (Ashmore) I move away from this here, to embrace the principles underlying the terminology of Schiffer, in the hope that this will make things a little clearer for the reader. Thus, where the term 'midden-site deposits' was used in SAIR 3 (ibid), the term 'anthropic deposit' is used in this paper to emphasise the fact that a deposit of this type is characterised by its anthropic content rather than its natural (shell-sand) matrix.

\section{$5.3 \quad$ ANTHROPIC DEPOSITS}

An anthropic deposit is a deposit whose matrix has been enriched with relatively large amounts of anthropic material, artefactual and ecofactual, where the material has not entered the deposit as a result of deliberate dumping. Rather, the anthropic material arrived in these contexts by some combination of loss (accidental dumping), abandonment (of butchery waste, for example, at a primary butchery site), or incidental discarding (littering).These contexts can be quite extensive and where sufficiently extensive are perhaps better described as anthropic soils, rather than deposits. This distinction is based on the probability that anthropic material has been incorporated into an existing matrix or was progressively included into a matrix being formed 
by natural processes. Anthropic deposits can also be created where dumped or other deposits have been cultivated and further manured, but these deposits are treated as 'cultivated deposits' (see below).

\subsection{MIDDEN SITES}

A midden site is a site composed principally of anthropic deposits but which includes other types of deposit within the machair system. This term substitutes for the archaic term 'kitchen midden'.

\subsection{CULTIVATED DEPOSITS}

Virtually all of the deposit types encountered on machair sites exist also in hybrid or mixed forms, and cultivation is the most frequent cause of their hybridisation. Dumped deposits or anthropic deposits are the most commonly cultivated deposit types. The resulting cultivated horizon (it can and probably always does include more than one original deposit) is usually so heterogeneous that it is not often possible, unambiguously, to identify the nature of the parent deposits. Further, there seems to be a more or less continuous spectrum embracing cultivated dumped or anthropic deposits, highly manured cultivated sands and plaggen soils. Of course, the practice of making soils continues to this day in the Hebrides, with the Lewisian Black Earths compounded of mineral soil, peat and shell sand in varying combinations which form extensive areas of cultivated land in Lewis and Harris. Glentworth $(1979,134-35)$ has commented on the heterogeneity of these anthropogenic soils in the Hebrides, which extend to their composition, superficial forms and the patterns of their use. It is probable that the cultivated deposits of the machair sites would not look out of place in modern Lewis. In Orkney the anthropogenic soils associated with Norse settlement (the Bilbster Soil Series) are sufficiently extensive to have been mapped and categorised by the Scottish Soil Survey. 


\section{PRESERVATION IN MACHAIR SOILS}

Preservation of calcium-based materials in machair sites is facilitated by the high $\mathrm{pH}$ of the shell-sand matrix. Materials that are relatively rare on Scottish sites, bone (animal, human, fish and bird) and shell (sea, snail and egg), survive in relative abundance on machair sites. The soft, uncompacted matrix means that pottery sherds survive in abundance. Even in cultivated, heavily trampled or re-worked deposits, potsherds survive in large numbers. With the enhanced survival of sherds, it is possible to use the distribution of sherd sizes from a context as an index of the extent of turbation of that context. Iron and other metals are rare in the machair sites and even slag is relatively uncommon. However, hammer scale and very small fragments of casting flash are regularly encountered in these sites. This implies that metals would have survived on-site, had they been deposited there. The relative absence of metal objects implies that cultural factors, like the heirloom status of metal objects, precluded their accidental or deliberate inclusion in machair deposits.

The range and abundance of material recoverable from machair has met with the usual responses from finds specialists; and typologies have been formed in varying degrees of sophistication for individual sites. Most of these have proved utterly inapplicable on other sites. The pottery sequences proposed by various authors are sui generis to their sites and indeed more often than not even conflict with the evidence from that site's stratification. Of the available typologies only that for pins seems broadly applicable, and the apparent duration of the currency of, for example, nail-headed pins means that they are not really chronologically diagnostic (A Heald pers comm). Though this writer cannot demonstrate it, he surmises that the characterisation of entire site assemblages and the phenomenon of assemblage-variation over time may prove a more useful diagnostic than our current emphasis on individual material typologies, much less our reliance on isolated exotic imports for dating of sites and deposits (Clarke 1971).

\subsection{CHRONOLOGY-BUILDING ON MACHAIR SITES}

As we might expect with depositional environments that are so dynamic, the rates of deposition on machair sites can be very high. Sets of deposits between $2 \mathrm{~m}$ and $3 \mathrm{~m}$ deep were formed at Hornish Point, Balelone and Baleshare in periods of time too short to be resolved by the radiocarbon method. However, the correspondence between radiocarbon dates and stratigraphic position is uniformly excellent. Thermoluminescence dates, including OSL dates, are far too imprecise for meaningful use in this rapidly accreting environment. Traditional archaeological dating strategies may not provide the most productive approach to chronology-building in machair sites. The traditional strategy has been to radiocarbon-date contexts that have significant contents or that date or bracket the foundation of structures. This inherently unsatisfactory practice has an even greater than usual capacity for misleading results in machair sediments because so many of the richest deposits are conflation deposits and thus are diachronic. However, machair-site sediments usually form coherent depositional systems, and reliable chronologies can be formed by dating the sedimentation process rather than by cherry-picking specific events within it.

\subsection{LOSS OF SEDIMENTS}

Ard marks in the cultivated deposits are sometimes filled with material that differs not only from the deposit in which they are found but also from the overlying layer through which, in theory, they were cut. I have interpreted some of these occurrences as evidence for the loss of the upper part of the cultivated horizon. During my stay in the Uists I have seen examples of the desiccation and resultant aeolian erosion of cultivated fields during the summer months. To limit this, the farmers set their ploughs very shallow in an attempt to preserve the root mat in situ, as an obstacle to erosion.

\subsection{PRACTICAL PROBLEMS IN THE USE OF RADIOCARBON DATING ON MACHAIR SITES}

The machair environment presents some severe challenges to the radiocarbon method. Driftwood from the Americas is regularly found on the Hebridean beaches (Dickson 1992) and was no doubt used in antiquity as fuel and for structural timbers, as it still is. Peat was widely used as a fuel, and carbonised twiggy material from burned or charred peat is also commonly encountered in site deposits. Unburnt and charred peat was also abundant in the sites I have examined (Barber 2003). Carbonised material like charcoal or seeds is highly mobile in the machair environment and pockets of carbonised materials have been observed forming behind stones or in shallow depressions in current deflation horizons. Clearly, this material may have derived from any number of discrete contexts, the matrix of which has been blown away. The impacts of these 
problems can be mitigated by proper identification and by careful study of the taphonomic processes involved in the formation of the deposits in which the samples are found. However, they cannot be eliminated completely.

The 'old-wood' problem may prove particularly severe in machair areas also because of the general scarcity of trees. In addition, large timbers were curated and acquired heirloom status. Loss of such timbers by accidental conflagration, for example, would incorporate in apparently 'sealed' contexts dating samples that are significantly older than the contexts from which they come. Taken as a whole, cereal grains from well-defined and taphonomically well-understood contexts probably constitute the only carbonised material that holds much prospect of providing reliable dating.

The marine reservoir effect complicates the radiocarbon assay of sea shell which is abundant in almost every context encountered in the machair sites. Carbonised cereals and sea shells from an inadequately small number of samples from these sites were dated, in an attempt to examine the stability of the marine reservoir effect, and these seemed to suggest that Harkness' standard correction, that is $405 \pm 40$ for marine reservoir effect was not perhaps as universally applicable as had been believed (Harkness 1983). A research programme was initiated (Barber 2003, 18.12.1) to examine the hypothesis that this relationship was not a constant. First results (Ascough et al 2004, 2005a, 2005 b \& 2006) indicate that our suspicions were well founded and specifically, that a reduction of 80 years should be applied to the standard 405 years for date in the few centuries either side of the beginning of the Christian millennium. It is ironic, perhaps, to note that had we ignored our concerns and applied Harkness' correction factor we would have been closer to a defensible estimate of true age than we would have been had we argued for the use of determinations completely uncorrected for marine reservoir effect. The significance of the dating of the Hebridean sites will be considered in a forthcoming paper (Barber et al forthcoming) which this writer hopes will resolve any confusion his treatment of the chronologies has created.

Whom the Gods wish to destroy ... Radiocarbon dates for the Iron Age machair sites wreak a final indignity on the archaeologist. Significant numbers of these Iron Age dates lie in what Baillie (Baillie \& Pilcher 1983) has described as the disaster zone of the first millennium $\mathrm{BC}$ calibration curve, making their calibration extremely problematic. In practice, adjusted for the revised MRE value, the dates for the sites reported upon in SAIR 3 (Barber 2003), in the main miss the most difficult part of the curve. However, the problems posed in calibration for the first millennium BC are real, and are significantly amplified for sites from which there are only single or few dates. It further complicates the issue of inter-site comparability of site chronologies in the treatment of which the greatest caution should be exercised.

It is perhaps ironic that so many problems attach to the dating of sites so exceptionally rich in potential dating material. There is clearly a need for some sophistication in the design of chronologybuilding strategies for these sites. These strategies must rely on 'absolute' methods, and radiocarbon dating is the only practicable method available to us. For the foreseeable future artefactual dating will have to be derived from radiocarbon dating, and while the proposed material typologies are undoubtedly of general interest, their chronological value remains to be demonstrated. We may hope for further improvements in the techniques of radiocarbon dating and its calibration, but it should be clear that a meaningful understanding of the taphonomic processes of deposit formation within machair sites will remain an absolutely essential prerequisite to their successful dating. 


\section{CURATORIAL RESPONSE}

The sites examined in this writer's campaign in the Outer Hebrides are actively eroding. Balelone has now been totally removed by the encroaching sea and the erosion faces of all the other sites now lie up to $10 \mathrm{~m}$ back from the faces examined by AOC in 1983-85. As part of the work of the final season on these sites, we cored extensive areas behind the known sites. Subsequent survey and other work by Sheffield University has also explored the machair, especially that of South Uist (see Parker Pearson et al 1999, which references earlier works in the SEARCH project and see Parker Pearson in this volume, for a SEARCH bibliography). It seems reasonable to conclude that the sites we can now see represent the greater part of the available resource of such sites. They are without doubt amongst the richest sites in Scotland, particularly for the Iron Age, but are of great significance for the deposits of all periods that they contain. By the internationally (Burra Charter 1999) and nationally (proposed new Scheduling criteria, HS 2005a) agreed criteria for the determination of cultural value, these sites are of national importance and, in the opinion of this writer, the Hebridean coastline is a cultural landscape of the organically evolved type and of the relict species (UNESCO 1999). As a group of sites, this cultural coastline is of international significance for the way in which the machair sites and the machair system demonstrate the evolution of the relationship between people and place over time.

The curatorial response to the loss of these sites has been inadequate. That is not to say that nothing has been done or nothing achieved; neither conclusion is fair. But the scale and duration of our investigations of these machair sites is wholly inadequate and their continuing and certain loss reflects poorly on those charged with their preservation, even if that preservation can now only be achieved by record. The recently published volume on coastal erosion sites in Scotland (HS 2005) bears witness to the work of surveys already undertaken, but this is only of academic interest to administrators and students of heritage management. Heritage value will not accrue until we move forward with programmes of on-site management, recording and salvage, augmented by extensive excavation analysis and publication of some of these remarkable sites.

Future generations will rightly hold us to account if we fail to make a response to this threat that is commensurate with the value of these sites and the scale of our potential loss. 


\section{REFERENCES}

Ascough, P L; Cook, G T; Dugmore, A J; Barber, J; Higney, E \& Scott, E M 2004 'Holocene variations in the Scottish marine radiocarbon reservoir effect', Radiocarbon 46, 611-620.

Ascough P L; Cook, G T \& Dugmore, A J 2005a 'Methodological approaches to determining the marine radiocarbon reservoir effect', Progress in Physical Geography 29, 532-547

Ascough P L; Cook G T; Dugmore A J; Scott E M \& Freeman, S P H T 2005b 'Influence of mollusc species on marine $\Delta \mathrm{R}$ determinations', Radiocarbon 47, 433-440.

Ascough P L; Cook G T; Church M J; Dugmore A J; Arge, S V \& McGovern, T H 2006 'Variability in North Atlantic marine radiocarbon reservoir effects at $c 1000 \mathrm{AD}$, The Holocene $16,131-136$.

Baillie, M G L \& Pilcher, J R 1983 'Some observations on the high-precision calibration of routine dates', in B S Ottaway (ed) Archaeology, dendrochronology and the radiocarbon calibration curve, 51-63. University of Edinburgh Department of Archaeology Occasional Paper No. 9, Edinburgh.

Barber, J 2003 Bronze Age Farms and Iron Age Farm Mounds of the Outer Hebrides. SAIR 3, Edinburgh.

Barber et al forthcoming. 'Radiocarbon and Other Chronologies for Iron Age Settlement in the Hebrides'.

Boyd, J M (ed) 1979 'The Natural Environment of the Outer Hebrides', Proceedings of the Royal Society of Edinburgh $77 b$.

Burra Charter 1999, www.icomos.org/australia/ burra.html.

Butzer, K W 1982 Archaeology as Human Ecology. Cambridge University Press, Cambridge.

Clarke, D L 1971 'Small finds from the Atlantic
Province, some problems of approach', Scot Archaeol Forum 3, 22-54.

Dickson, J H 1992 'North American driftwood, especially Picea (spruce), from archaeological sites in the Hebrides and Northern Isles of Scotland', Rev Palaeobotany \& Palynology 73, 49-56.

Glentworth, R 1979 'Observation on the soils of the Outer Hebrides', in J M Boyd (ed) 1979, $123-137$.

Harkness, D D 1983 'The extent of natural 14C deficiency in the coastal environment of the United Kingdom', 14C and Archaeology Conference proceedings, PACT 8, 351-63.

Hill, J D 1995 'Ritual and rubbish in the Iron Age of Wessex: a study on the formation of a specific archaeological record', BAR Brit Ser, 242.

HS 2005 Coastal Archaeology and Erosion in Scotland. Conference proceedings, Historic Scotland, Edinburgh.

HS 2005a 'Appendix 1: revised guidance and criteria [for Scheduling]', www.scotland.gov. uk/library5/education/rcon302-02.asp

Needham, S \& Spence, T 1997 'Refuse and the formation of middens', Antiquity 71, 77-93.

McOmish, D 1996 'East Chisenbury: ritual and rubbish at the British Bronze Age transition', Antiquity 70, 68-76.

Parker Pearson M; Sharples N; Mulville J \& Smith H 1999 Between Land and Sea: Excavations at the Broch of Dun Vulan, South Uist. SEARCH monograph 3. Sheffield Academic Press, Sheffield.

Ritchie, W 1979 'Machair development and chronology in the Uists and adjacent islands', in J M Boyd (ed) 1979, 107-122.

Schiffer, M B 1987 Formation Processes of the Archaeological Record. University of Utah Press, Utah.

UNESCO 1999, see www.who.unesco.org 



\title{
Archaeological remains on Uist's machair: threats and potential
}

\author{
by Mike Parker Pearson, \\ Department of Archaeology, University of Sheffield, Sheffield \\ Jacqui Mulville and Niall Sharples \\ School of History and Archaeology, University of Cardiff, Cardiff \\ Helen Smith \\ Department of Conservation Science, University of Bournemouth, \\ Bournemouth
}





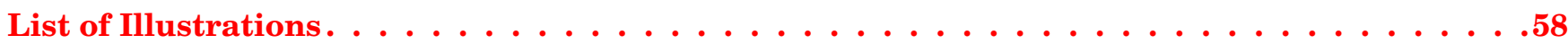

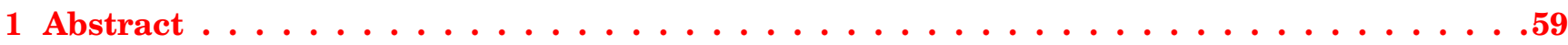

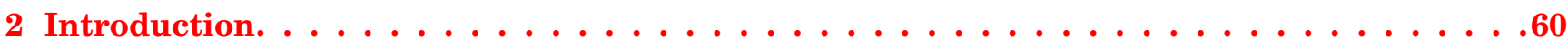

3 The Principal Threat to Machair Sites: Rabbit Damage . . . . . . . . . . . . . . . .62

4 The Quality of Archaeological Evidence on the Machair . . . . . . . . . . . . . . . . . .64

4.1 Stratigraphy and preserved floor accumulations . . . . . . . . . . . . . . . . 64

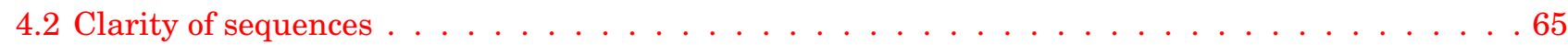

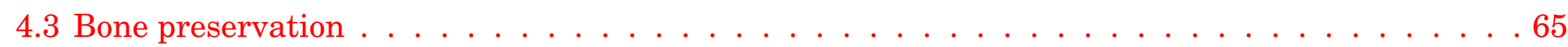

4.4 Juxtaposed calcareous, acidic and waterlogged conditions. . . . . . . . . . . . . . . 65

5 The Machair Sequence of Settlement and Land Use . . . . . . . . . . . . . . 67

6 Development of Archaeological Methods and Techniques . . . . . . . . . . . . . . . .69

6.1 Environmental archaeology . . . . . . . . . . . . . . . . . . . . 69

6.2 From tapestries and test pits to open-area excavation. . . . . . . . . . . . . . . . 69

6.3 Analysing house floors . . . . . . . . . . . . . . . . . . . . . . . 699

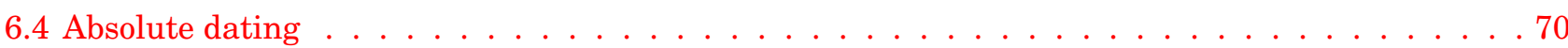

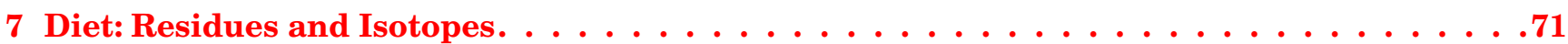

7.1 Inferring mummification from skeletons $\ldots \ldots \ldots \ldots \ldots \ldots \ldots$

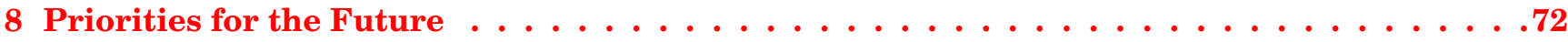

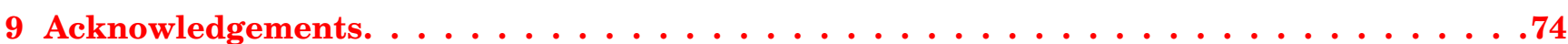

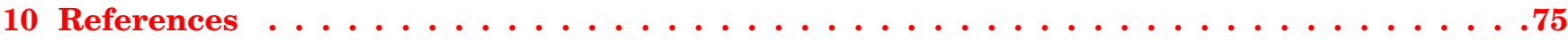

11 A Bibliography of the 'SEARCH' Project $\ldots \ldots \ldots \ldots \ldots \ldots$

11.1 Monographs. . . . . . . . . . . . . . . . . . . . . . . 77

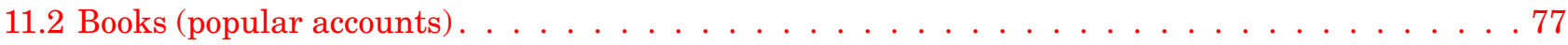

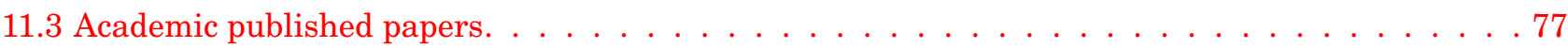

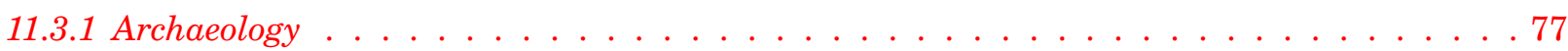

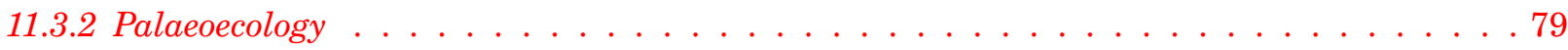

11.3 .3 Ecology. . . . . . . . . . . . . . . . . . . . . . . . 81

11.4 Popular accounts $($ not including newspaper reports) $\ldots \ldots \ldots$. . . . . . . . . . 82

11.5 Unpublished reports (not including $\mathrm{MSc}$ and $\mathrm{PhD}$ theses) . . . . . . . . . . . . . . . 82

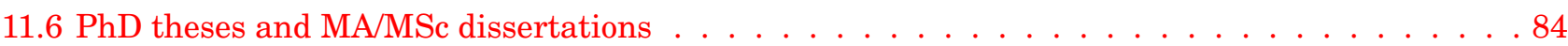




\section{LIST OF ILLUSTRATIONS}

1 The southern islands of the Western Isles . . . . . . . . . . . . . . . . . . . . . 60

2 The Norse settlement of Cille Pheadair during excavation . . . . . . . . . . . . . . . . . . 62

Rabbit damage of machair settlement mounds . . . . . . . . . . . . . . . . . . . 62

The floor accumulation within a roundhouse (House 1370) at Cladh Hallan . . . . . . . . . . . 64

The fill within a pit (Pit 2508) at Cladh Hallan . . . . . . . . . . . . . . . . . . . 65

Excavating waterlogged deposits at the broch of Dun Vulan, South Uist . . . . . . . . . . . 66

A Pictish-period skeleton buried under a cairn at Cille Pheadair . . . . . . . . . . . . . 67 Phosphorus, nitrogen and magnetic susceptibility sampling

(late Norse barn at Bornais, South Uist) . . . . . . . . . . . . . . . . . . . . . . . . 69

9 Flotation sampling at Cladh Hallan, South Uist . . . . . . . . . . . . . . . . . . . . .70

10 Jim Symonds and the information board at the Flora MacDonald Birthplace,

Airigh Mhuillin. . . . . . . . . . . . . . . . . . . . . . . . . . . 72 


\section{ABSTRACT}

Since 1987 Sheffield University and latterly other universities have carried out archaeological investigations of archaeological sites on the machair of South Uist, Barra and the southern isles of the Western Isles (Outer Hebrides) as part of the SEARCH project. The remains often survive extremely well as stone-walled dwellings with intact floors, set within deeply stratified settlement mounds, dating from the Beaker period to the Post-Medieval period. This exceptional archaeological resource has come under threat especially from rabbit-burrowing as well as from coastal and wind erosion. The good preservation of floors and other features has helped in the development of new archaeological methodologies and techniques as well as providing exciting new evidence of Hebridean life through the millennia. A bibliography of the SEARCH project is appended. 


\section{INTRODUCTION}

Since 1987 Sheffield University has undertaken a major research project investigating the archaeological and environmental aspects of settlement in the southern islands of the Western Isles of Scotland (SEARCH, or Sheffield Environmental and Archaeological Research Campaign in the Hebrides). Over the years the project has grown, drawing in col- laborators from other universities, principally Bournemouth, Cardiff, Aberdeen and Boston but also Edinburgh, Oxford, Bradford, Southampton, University College London, Winchester, Plymouth, Aberystwyth, Glasgow, Newcastle and Cambridge. The aims of the project were to investigate human adaptations to this island environment, and to

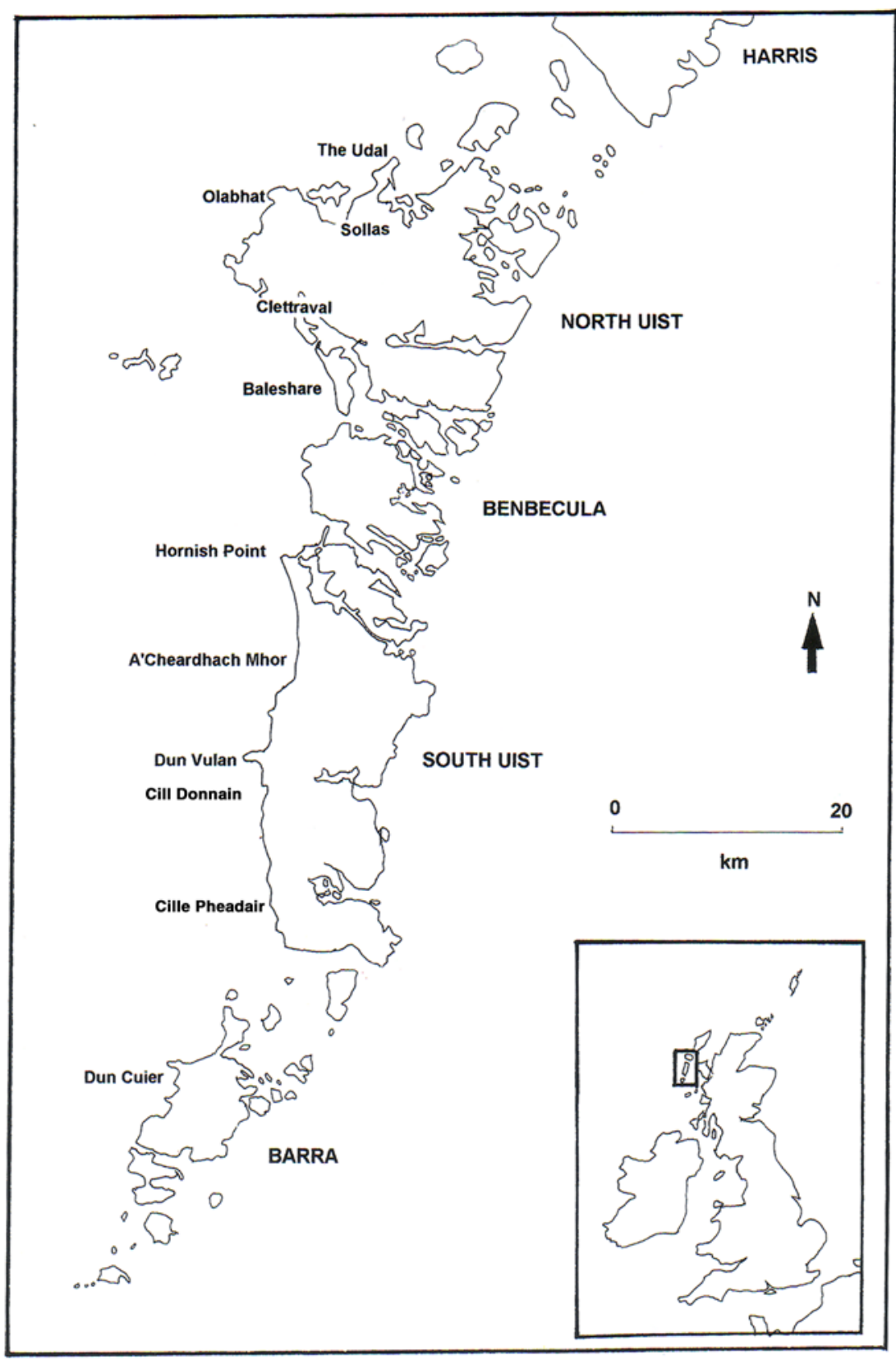

Illus 1 The southern islands of the Western Isles with main SEARCH excavations and earlier archaeological excavations marked. 
study the long-term processes of domestic and economic life, from earliest settlement until the nineteenth century. Much of the fieldwork on the islands of Barra and South Uist (as well as on the small isles surrounding them) has been carried out on the peatlands and rocky moorlands, but a major contribution to the project (especially on South Uist) has come from survey and excavation on the machair plains of calcareous sand on the west coast (illus 1).

Eighteen years on, the project has produced two popular books, six monographs (with seven more to come) and well over 100 published academic papers, along with a string of articles in popular magazines and newspapers both locally and worldwide (see Bibliography of the SEARCH Project below). The project has been a training ground for British and American archaeology, producing $12 \mathrm{PhD}$ theses and
22 Masters dissertations as well as training around 1,000 archaeology students, Earthwatch volunteers and local participants. Five of the project's seven large set-piece excavations have been carried out on settlement sites on South Uist's machair, and the entire $35 \mathrm{~km}$ length of this island's kilometre-wide strip of machair has been prospected for archaeological remains. Previous investigations such as Kissling and Lethbridge's excavation of a well-preserved Iron Age wheelhouse at Cille Pheadair (Lethbridge 1952), the 'Rockets Galore' project involving rescue excavation on the South Uist rocket range (Young \& Richardson 1960; Fairhurst 1971; MacLaren 1974) and the Outer Hebrides farm mound project (Barber 2003) can now be reassessed within their broader archaeological context. For a more detailed account, see South Uist: Archaeology and History of a Hebridean Island (Parker Pearson et al 2004). 


\section{THE PRINCIPAL THREAT TO MACHAIR SITES: RABBIT DAMAGE}

In 1996 the SEARCH project undertook a management audit of the archaeological sites surviving on South Uist's machair (Parker Pearson 1996a). Some 234 archaeological sites have been identified within this machair strip, most of them previously unrecorded. The vast majority of them are settlement mounds of varying sizes from $5 \mathrm{~m}$ to over $100 \mathrm{~m}$ in diameter. Of these, 30 were found to be suffering from erosion by human or natural agency. In some cases, the impact was severe: sand quarrying at Cladh Hallan, coastal erosion at Cille Pheadair (illus 2) and Dun Vulan, ploughing at Bornais and wind erosion at Cill Donnain were among the most serious threats. In all such cases where the machair's grass surface was broken, the damage was compounded by wind erosion, which has led to sand blowouts and deflation of archaeological layers.

Yet there is a more insidious threat to the archaelogical remains of the Western Isles. Rabbits have

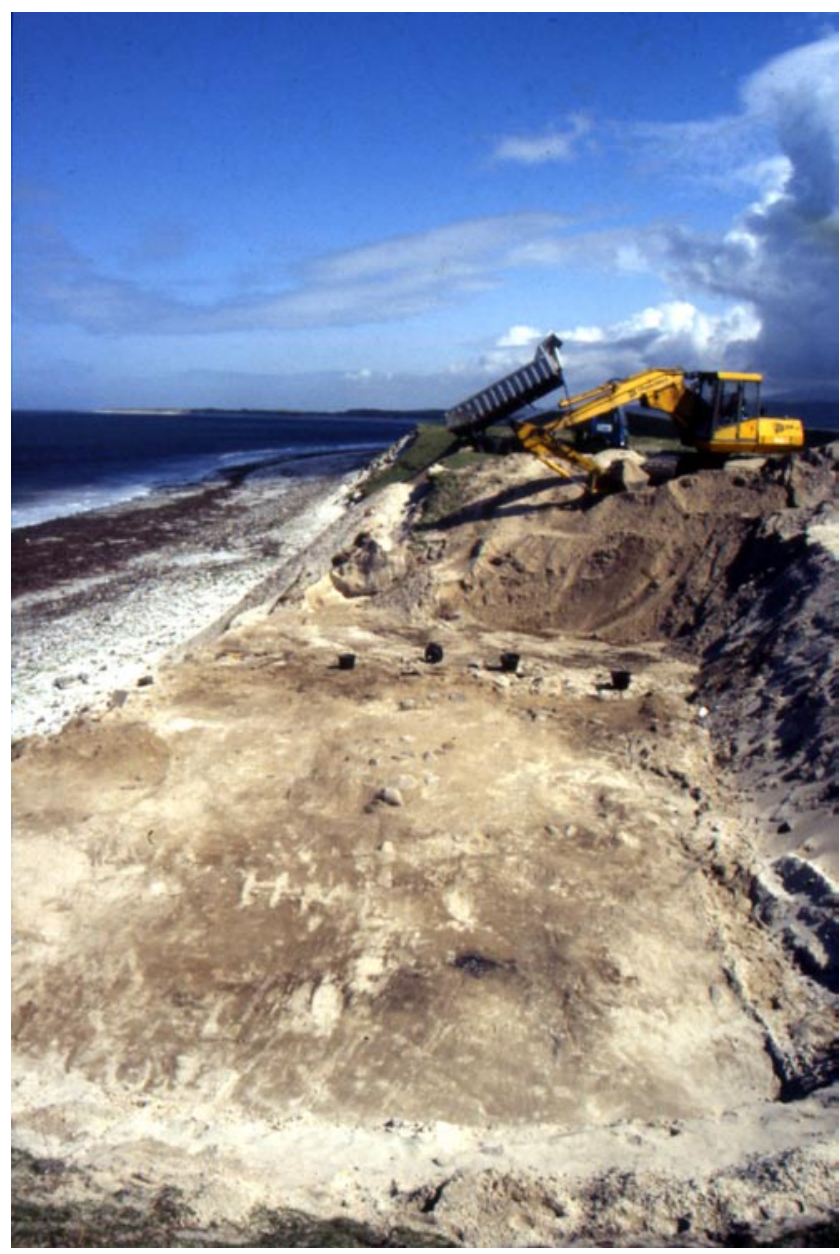

Illus 2 The Norse settlement of Cille Pheadair during excavation. Exposed by the sea in 1992, it has since been almost entirely washed away. been resident in these islands for many centuries, but only in the last 40 years have their numbers exploded to the level of an infestation. Previously they were hunted with dogs but the introduction of myxomatosis resulted in their no longer being considered fit for human consumption. There are various local schemes to gas and kill rabbits but, without a concerted programme of extermination, they soon recolonise those areas of machair from which they have been cleared.

The reasons for the current rabbit clearance programmes are agricultural and ecological, and have nothing to do with archaeological priorities. However, rabbits cause extraordinarily high levels of damage to the deeply preserved stratigraphic sequences within the settlement mounds' soft sand (illus 3). Their burrowing reaches to depths below $1.5 \mathrm{~m}$, digging through stratified floors and other layers, dislodging stones, destroying stratigraphic relationships by burrowing along wall lines, and moving material from below ground to the surface. The latter process has been extremely useful to archaeologists prospecting for occupation sites in otherwise unbroken machair grassland. However, the overall physical impact on these archaeological sites, whose stratigraphic sequences may be up to $3 \mathrm{~m}$ deep, is to turn them from layer cakes to increasingly hole-riddled Swiss cheese. The cumulative effect on these sites has been so great in the project's lifetime that we may expect the vast majority of these settlement mounds to be 'de-stratified' within the 21st century.

Programmes of gassing and eradication of rabbits are the only way forward if this new threat is to be halted (unless they once again become a human

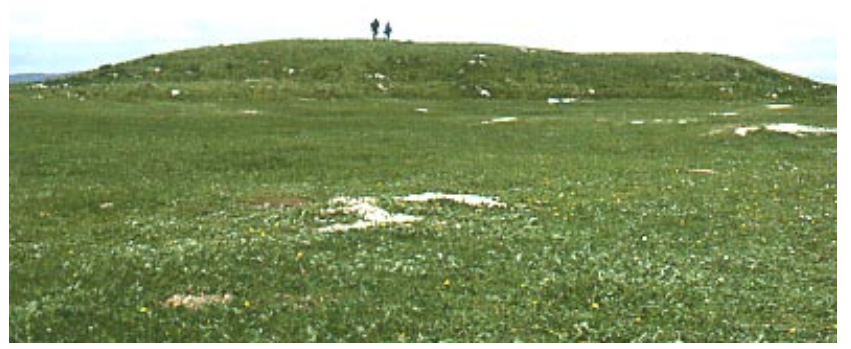

Illus 3 Rabbit damage of machair settlement mounds is extensive. White sand marks the locations of burrows into a prehistoric mound at Machair Meadhanach, South Uist. 
food resource as in pre-myxomatosis times). Whilst gassing has been carried out in recent years, its effects are temporary and partial, allowing rabbit colonies to re-infest previously cleared areas. The rabbit will probably never be eradicated from these islands but it may be possible to keep it at low numbers through regular pest control. At the same time, rescue excavation will still be required on settlement mounds and other sites suffering from damage by rabbit burrowing. 


\section{THE QUALITY OF ARCHAEOLOGICAL EVIDENCE ON THE MACHAIR}

Although the machair is largely unoccupied today, it was densely occupied in later prehistory and the early historic period, as indicated by more than 200 surviving settlement mounds along 20 square miles of South Uist's west coast. The most important feature of these abandoned settlement sites is their tell-like formation into deeply stratified mounds as the result of accumulative processes of sand deposition. This appears to have been due in large measure to the ability of ancient stone structures and organic-rich layers to trap sand as it was blown inland off the beach, either forming clean layers of windblown sand or becoming mixed with occupation-derived detritus.

Geophysical methods of magnetometry, magnetic susceptibility, resistivity and ground-penetrating radar (GPR) have been used with success on the settlement mounds of the machair (Hamilton \& Sharples 1996; Sellers \& Chamberlain 1999). In particular, Mike Hamilton's magnetometry and resistivity survey of the Norse-period mounds at Bornais identified traces of 22 buildings, mostly arranged into farmyard clusters. For those settle- ment remains buried deeply beneath windblown sand, GPR has been of use, capable of detecting built stone features at $3 \mathrm{~m}$ depth, as was confirmed at Cladh Hallan. Coring has also been used successfully, for example to recover the extent and contours of an Early Bronze Age Cordoned Urn settlement mound beneath the Iron Age settlement at Cill Donnain (Parker Pearson 2003; Parker Pearson \& Seddon 2004). Nonetheless, these prospection techniques provide only the crudest indications of what lies buried beneath. They are no substitute for excavation.

\subsection{STRATIGRAPHY AND PRESERVED FLOOR ACCUMULATIONS}

The depth and quality of stratigraphy in these settlement mounds is their most important feature. Unlike the largely eroded, ploughed and truncated sites of mainland Britain, these small 'tells', with their long chronological sequences, are a remarkable archaeological survival (a potential first appreci-

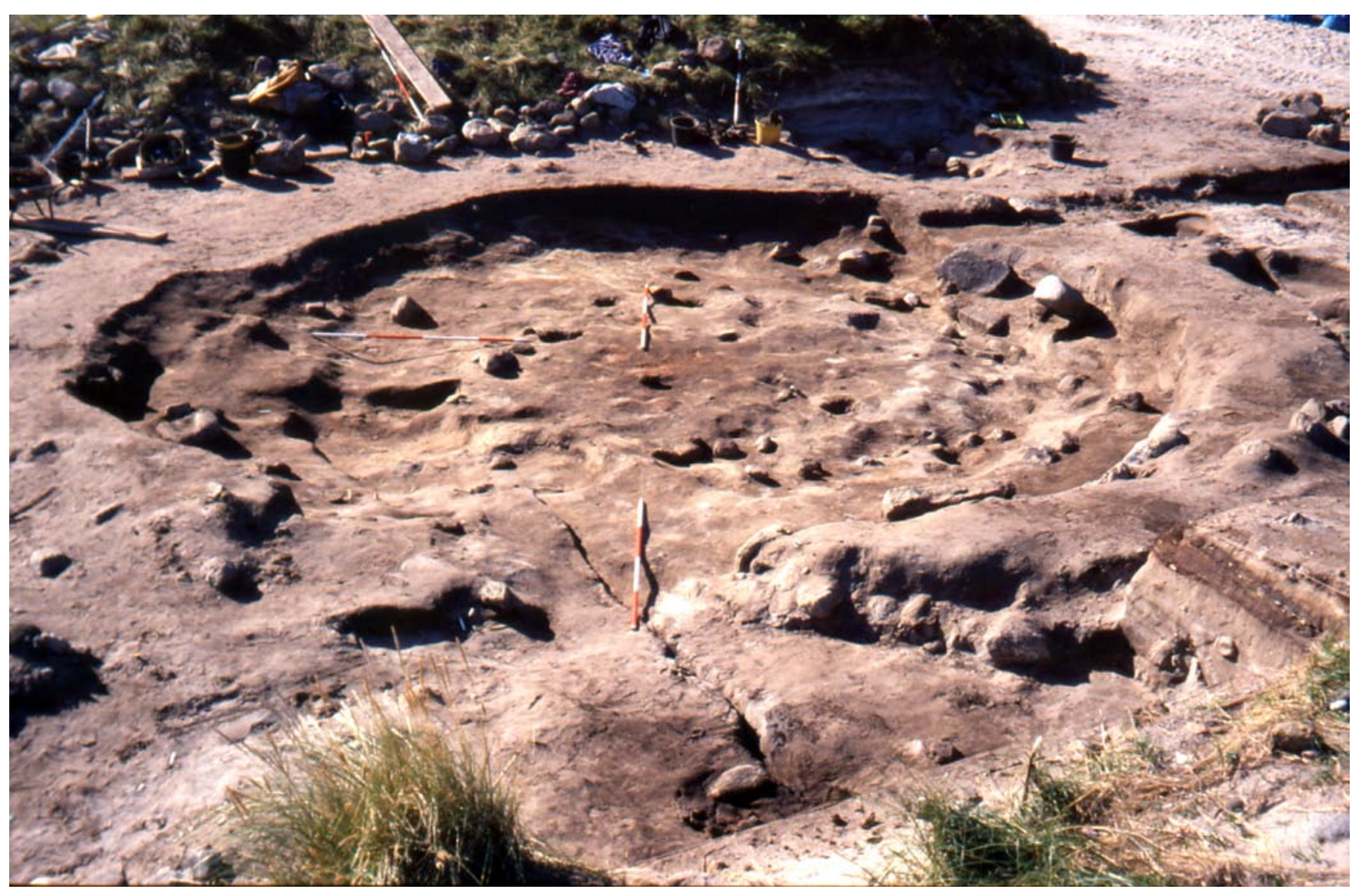

Illus 4 The floor accumulation within a roundhouse (House 1370) at Cladh Hallan. 
ated fully by Iain Crawford in his excavations at the Udal in North Uist (Crawford, 1986)). Among the complex deposits of windblown sand, fill layers, construction dumps and abandonment layers, there are also preserved house floor deposits. By happy accident, the floor accumulations within the vast majority of dwellings - whether from prehistoric times or later - were formed of a soft mixture of peat and sand, trapping micro debris where it fell (illus 4). This has given archaeologists a perfect opportunity to study activity patterning within houses in a way which is not often possible in the stone-paved buildings that are more common in, for example, the Northern Isles.

In some circumstances, as Werner Kissling and Tom Lethbridge found at Cille Pheadair (Lethbridge, 1952), dwellings and other stone buildings might be abandoned wholly intact except for their roofs, providing a degree of architectural survival which is exceptional for prehistoric remains. In other situations houses burnt down, leaving the burnt roof spars as a charred lattice on top of the abandoned floor, as in the Pictish-period house at Bornais (Sharples 1999). More often, however, the materials from abandoned buildings were regularly 'robbed' and reused in later structures, thereby recycling the stone (which does not occur naturally on the machair) from generation to generation. Fortunately, most house floors have, in our experience, survived the ravages of time (at least until the rabbit population explosion of the last two decades). This is due, in part, to what may have been reluctance by later generations to dig new footings below the levels of previous floor surfaces.

\subsection{CLARITY OF SEQUENCES}

The visual discrimination of different layers within machair sites can be exceptionally fine, although it can become impossible in dry conditions. Sections through archaeological sequences are often a riot of colours - red, orange, yellow, brown, grey, black - as each layer, however thin, can be picked out with

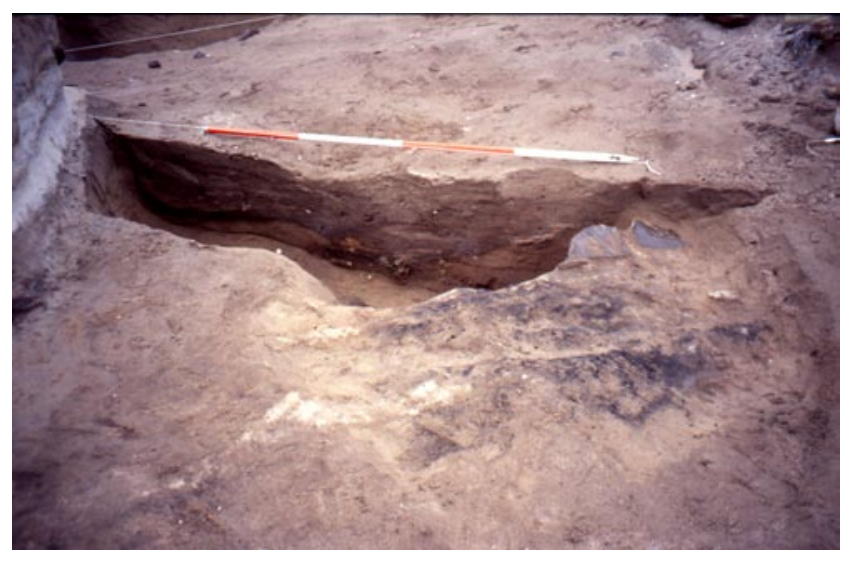

Illus 5 The fill within a pit (Pit 2508) at Cladh Hallan, exhibiting clearly differentiated layers in machair sand. clearly defined boundaries (illus 5). Even where the wind-accumulated sand has been dug into with a pit immediately backfilled with the same, clean sand, the experienced archaeologist can identify the cut by the feel (and sound on the trowel) of the realigned sand grains. Interpreting the often complex stratigraphy of accumulating layers and cut features is certainly a challenge, but generally machair deposits are among the most rewarding to excavate in terms of context definition.

Episodes of windblown sand deposition can result in extensive layers across a large area of a settlement mound, allowing the identification of stratigraphic contemporaneity between otherwise unrelated contexts. It also provides a vanilla-white blanket of sand which protects outdoor surfaces, and sometimes ephemeral traces such as the hoofprints of cattle and other animals may be preserved along with the more robust plough furrows.

\subsection{BONE PRESERVATION}

Bone is well preserved in machair sand, although other organic materials do not normally survive (but see below). The calcareous component of the machair's shell sand is sufficiently alkaline $(\mathrm{pH}$ of 7.5-8; Hudson 1991) to preserve bones in excellent condition. The bones of small mammals, fish, birds, molluscs and large mammals are well preserved except in conditions where deposits are affected by groundwater or tides, when preservation may be slightly poorer. The fine sand makes complete dry sieving of all deposits (through a $10 \mathrm{~mm}$ mesh) and large-scale flotation (through $1 \mathrm{~mm}$ and 300 micron mesh sieves) relatively cost effective.

The islands have been largely treeless since $c 2500$ BC (Brayshay \& Edwards 1996) and past populations have used the bones of stranded whales and other cetaceans to fashion artefacts which elsewhere were made of wood. This means that an entire range of artefacts - flax beaters, weaving batons, smoothing boards, handles and so on - has survived in conditions where their wooden counterparts would have perished. Whale bones were also occasionally used as furniture, notably as cist covers. Handles of tools were commonly made of antler and bone although, in the appropriate waterlogged conditions, wood assemblages retain tool handles made of wood.

\subsection{JUXTAPOSED CALCAREOUS, ACIDIC AND WATERLOGGED CONDITIONS}

The calcareous machair and the acidic peatlands immediately to the machair's east provide a remarkable juxtaposition of landforms whose preservative properties are entirely different. The blanket bogs and freshwater lochs of the peatlands preserve sequences of pollen, beetles, timber and plant remains (unburnt) - materials which rarely survive in machair environments. These complementary 


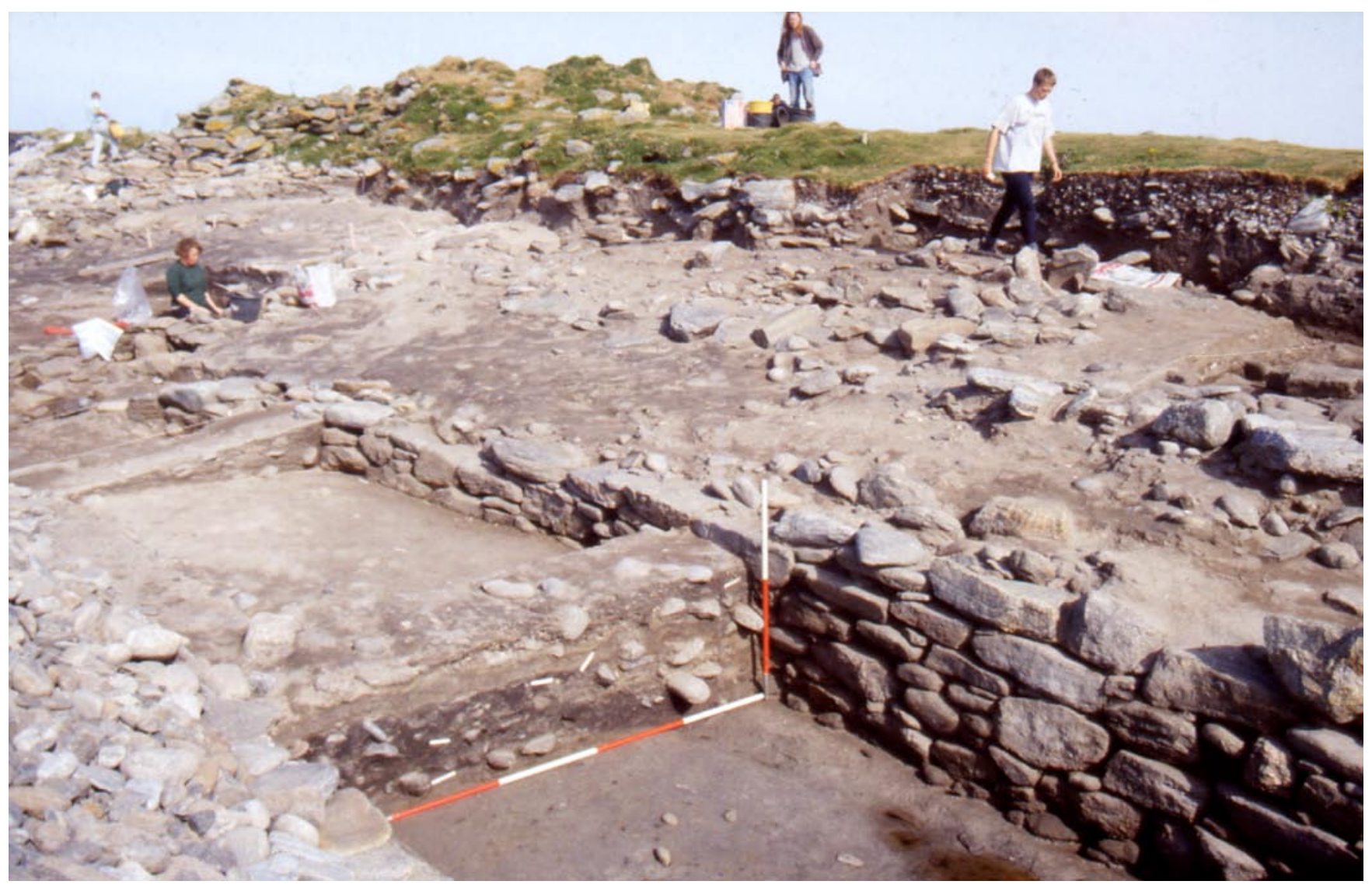

Illus 6 Excavating waterlogged deposits (foreground) at the broch of Dun Vulan, South Uist.

materials can provide useful information, especially on the natural environment, not otherwise available from the machair settlements. As a result, palaeoecological sampling sites are often close to contemporary archaeological sites on the machair, thereby providing a better insight into the impact of human activity on landscape change.

Very occasionally, long-term waterlogged contexts survive on the machair where all these forms of evidence - bone, molluscs, pollen, beetles, timber, carbonised and unburnt plant remains - survive in wet, alkaline conditions. This was the case along the waterfront at Dun Vulan (Parker Pearson \& Sharples with Mulville \& Smith 1999), where beetles and calcareous spherulites (identified by soil micromorphology) were used to infer the presence of a dung heap, and where artefacts of locally grown wood as well as of North American driftwood were recovered (illus 6). The remarkable preservation of this part of the Dun Vulan site is undoubtedly due to its having been built within a freshwater loch. Whilst most other Uist brochs are similarly located on islets within lochs, Dun Vulan's machair setting is highly unusual - most of the others are found in acidic peatland environments. This is because Dun Vulan was built on an islet within a freshwater loch that was inundated by machair sand (ibid, 58). 


\section{THE MACHAIR SEQUENCE OF SETTLEMENT AND LAND USE}

The calcareous sand plain formed in the third millennium BC, burying a land surface covered with freshwater lochs (Ritchie 1979). The earliest settlements that have been found on top of it in the Uists are small, low mounds of the Beaker period (2400-1700 BC). In South Uist, four such settlement nuclei have been found. The largest is at Iochdar, where it covers an area of about $150 \mathrm{~m}$ in diameter. Cross-ploughed fields have been identified at the Cladh Hallan and Cill Donnain settlements, and stray finds indicate settlement on the island's south coast at South Glendale (Barber 2003, 104-8). There were probably settlements off the machair in this period but they are difficult to find (for example, the Neolithic settlement at Allt Chrisal [also known as Allt Easdal] on Barra was only discovered during excavation of a nearby blackhouse (Branigan \& Foster 1995, 49-50). In later millennia, South Uist's peatlands supported only a few roundhouses, the vast majority of the settlements being located on the machair.

The three west coast locations at Cladh Hallan, Cill Donnain and Iochdar were favoured locations for settlement throughout the Bronze Age (2200800 BC). At Cladh Hallan the Beaker fields were inundated with sand and then reused as a cremation cemetery, on top of which an oval house was built around 1500 BC. Around 1100 BC this settlement was re-established as a terraced row of four or more sunken-floored, substantial roundhouses. Such nucleation is extremely rare, as prehistoric houses are normally found singly. The long-term settlement pattern of these islands, just like today's pattern, is one of dispersal.

The Late Bronze Age was a time not only of substantial houses but also of fast-accumulating settlement mounds. Whereas those mounds of the Early and Middle Bronze Age are rarely above $1 \mathrm{~m}$ in height, Late Bronze Age and Iron Age stratigraphic sequences are often over $3 \mathrm{~m}$. This difference may be due to various factors: increasing dwelling size (trapping more sand), abandonment of middening on surrounding fields and retention of refuse around the houses. At Cladh Hallan, the settlement mound was ploughed right up to the walls of the roundhouses, rather different from the previous practice of manuring fields at a distance from the dwellings.

Around $200 \mathrm{BC}$ there was a substantial increase in machair settlements, with mounds located about $1 \mathrm{~km}$ apart along South Uist's west coast, in contrast to the $8-15 \mathrm{~km}$ spacings of earlier machair settlement nuclei. Of course, coastal erosion may have destroyed some of these earlier settlement remains, but this Iron Age expansion is still remarkable. The historically recorded tradition of townships consist- ing of east-west strips across the island - with each managing a section of machair, peatland and eastcoast moorland (Caird 1979) - may have come into being at this time (Parker Pearson 1996b). The settlement pattern consisted of brochs (in use here by at least $100 \mathrm{BC}$ ) and roundhouses; the higher proportions of pig bones at sites like Dun Vulan suggest that broch inhabitants enjoyed dietary as well as architectural distinction from their roundhousedwelling neighbours.

In the Pictish period (AD 400-900) the settlement pattern was largely unmodified, with new settlements placed in close proximity to old ones or even reusing Iron Age dwellings (Mulville et al 2003). The reduction in house size and the emphasis on bodily adornment and presentation (Sharples 2004) suggest a growing involvement in long-distance social networks. It may be significant that the only Pictish burial from this period in South Uist (at

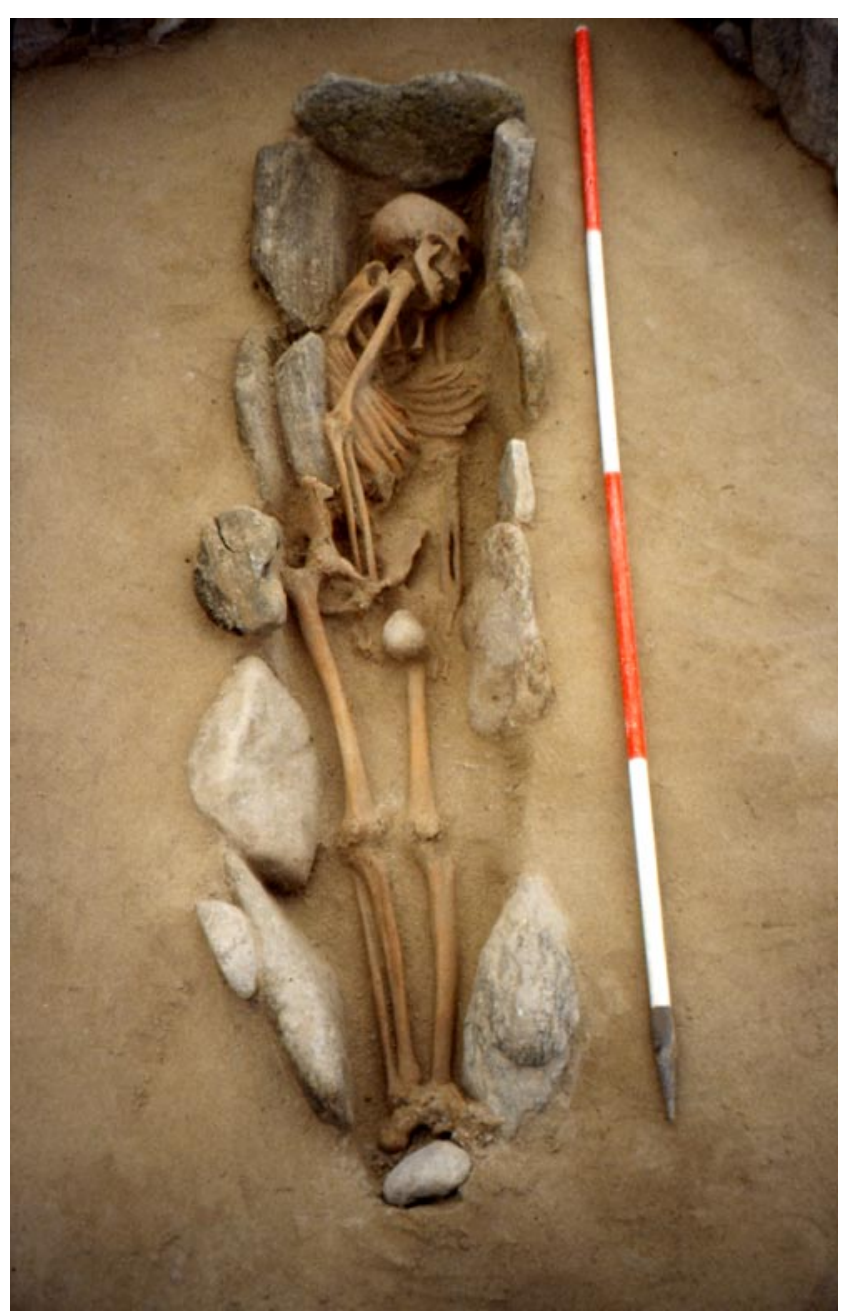

Illus 7 A Pictish-period skeleton buried under a cairn at Cille Pheadair. 
Cille Pheadair) is that of a woman (illus 7) who was an incomer, on the evidence of her strontium isotope levels (Janet Montgomery, pers comm).

The Norse period (AD 795-1266) began with a significant rupture in social and economic life, with longhouses replacing curvilinear architecture, a new emphasis on meat production rather than on dairying, and new crops such as flax and rye being cultivated. Shielings for summer grazing in the moorlands also probably came into existence in this period. There are strands of continuity, however, across this chronological divide. Pottery-making continued (albeit with a new ceramic technology), and there was a strong degree of continuity in settlement locations on the machair. At Cille Pheadair, a Pictish-style bone pin was found on the floor of the earliest farmstead, in use around AD 1020. In this period, one settlement grew larger than the others. Bornais (the name is derived from borg - broch - on the ness - promontory) was located in the middle of the island, close to the broch of Dun Vulan from which it probably takes its name, and is the only complex which was substantially bigger than a single farm.

In the Medieval period (AD 1266-1500) settlements began to decline on South Uist's machair. A few survived as late as the 17th-19th centuries, but many were abandoned towards the end of the 14 th century. The settlement at Bornais was finally left at some point in the 14th century, just as a new settlement sprang up $600 \mathrm{~m}$ away on the edge of the peatland at Bhac na Mhic Aongheis. This shift from machair to peatlands appears to have been widespread and long-term (Raven 2005). Its cause is not fully understood. Was it linked to population movements as people left for Scotland's towns? Was it due to greater use of the peatlands and moorlands for grazing? Or was it a response to increasing storminess causing devastation to machair-grown crops (Gilbertson et al 1999)? 


\section{DEVELOPMENT OF ARCHAEOLOGICAL METHODS AND TECHNIQUES}

Machair environments are not the easiest for excavation, given the strong winds and heavy rain that may come at any time of the year. In the 1960s and 1970s Iain Crawford was advertising in the CBA newsletter for 'mesomorphs' to join his team at the Udal. He also outlined how conventional excavation techniques such as maintaining permanent sections were unsuited to the fierce weather conditions and soft sand (Crawford 1978; Crawford \& Switsur 1977).

\subsection{ENVIRONMENTAL ARCHAEOLOGY}

Crawford was one of the first archaeologists working in Britain to employ flotation at the Udal, but it was really in the 1980s that John Barber's team brought a suite of environmental archaeological methods to machair excavation, with questions of subsistence and economy forming a substantial part of the research design (Barber 2003, 114-6). Studies of human, animal, bird and fish bones, charred plant remains, molluscs, phytoliths, pollen and diatoms accompanied the structural and artefact reports, highlighting the huge potential of machair sites and environments for integrated scientific analysis.

Most of the archaeological scientists working with John Barber were based at Sheffield University, and so it was a logical development for SEARCH to continue in this vein, refining and learning from the lessons already learned. David Gilbertson was largely responsible for training a generation of $\mathrm{PhD}$ students in the early years of this project, and it was their input which had a huge impact on the project's innovations and integration of methods. In particular, Helen Smith developed a methodology of analysing formation processes through an integrated suite of analytical techniques (Smith 1996) which has served as a guiding approach and way of thinking in subsequent years by developing analogues from her ethnoarchaeological analysis of farmsteads and agricultural activities.

\subsection{FROM TAPESTRIES AND TEST PITS TO OPEN-AREA EXCAVATION}

Dun Vulan was, hopefully, the last of the 'tapestry' excavations (in which a thin trench is cut along the eroding face of a mound). Machair settlement sites are extremely complex, and limited interventions are doomed to fail to understand the spatial ramifications of what is excavated. Tapestry excavations, test trenches and sondages can answer basic questions about sequence and chronology but they cause enormous damage on machair sites, making them methods of last resort. There is no substitute for open-area excavation.

The large-scale excavations at Bornais, Cille Pheadair and Cladh Hallan have demonstrated the merits of open-area digging with cumulative sections, planning and interpreting layers, positive features and negative features in ways that are simply not possible within narrow trenches. The folly of such approaches became clear after we had cut test pits into the main mound at Cladh Hallan. Only subsequently did we realise that identification and understanding of floor layers, interior and exterior space, house walls and fill layers had been impossible within narrow trenches. We could document sections but we couldn't satisfactorily understand them. At the same time, we dug through deposits - notably floor layers - which should only have been tackled in plan. It is now generally recognised that house interiors should be excavated in full - there is little point in excavating just part of a dwelling.

\subsection{ANALYSING HOUSE FLOORS}

Unlike houses in the Northern Isles, those of the Western Isles' machair have little in the way of stone 'furniture' or flooring. Often the mixed peat and sand floor layer is sealed beneath a fill of windblown sand, sometimes with an organic layer of decayed roof turfs and other vegetal matter lying between the floor and the clean sand (or interleaved with it). There may also be materials which have been left on the floor's surface, that are separate from the micro debris that has become incorporated into the floor matrix. To complicate matters further, floors

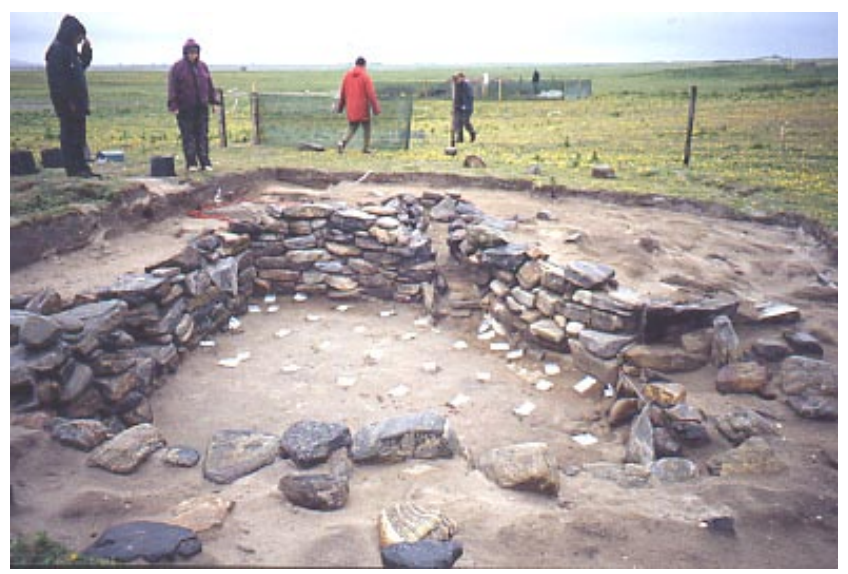

Illus 8 Phosphorus, nitrogen and magnetic susceptibility sampling on a $0.5 \mathrm{~m}$ grid within a late Norse barn at Bornais, South Uist. 


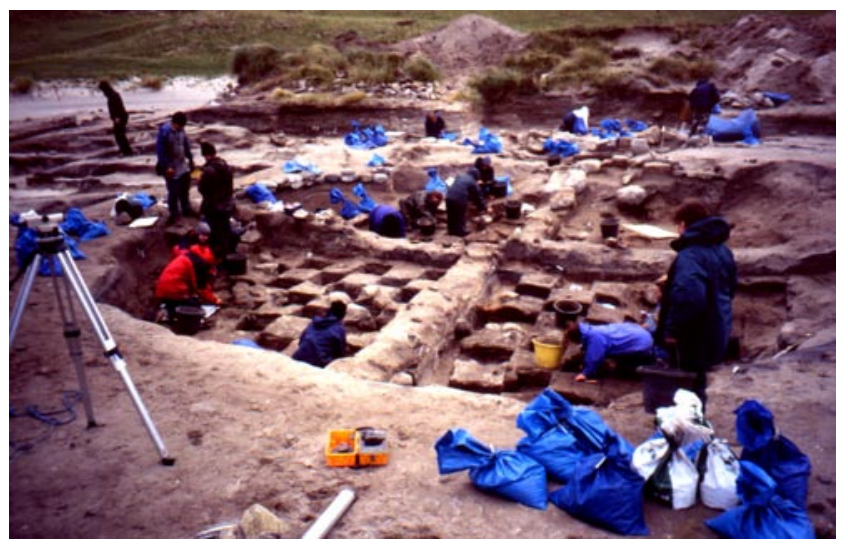

Illus 9 Flotation sampling in $0.5 m$ squares of house floors and yard surfaces at Cladh Hallan, South Uist.

were patched and relaid, with one example from the Norse period at Cille Pheadair incorporating artefactual and ecofactual material within the matrix before it was laid. The patterning of materials is also affected by sweeping, although the distinctive distributions left by sweeping are not found before the Norse period. We assume that, previously, rubbish was removed by hand.

Occupation of houses can present us with complicated sequences of use, abandonment and re-use. The middle roundhouse at Cladh Hallan, for example, was inhabited for about 900 years (although the nature and intensity of that inhabitation changed through time), with seven rebuilds and re-floorings (in which the old floor was covered with fresh sand on top of which a new floor was laid). In contrast, other houses exhibit far more discontinuity of inhabitation. The Norse farmstead at Cille Pheadair was periodically abandoned and reoccupied over a 200-year period (c1020-1220), as demonstrated by evidence of abandonment in the form of rebuilds, windblown sand layers, owl pellets and human and animal faeces. In such studies, soil micromorphology, analysis of small mammal bones and plotting of faeces have complemented conventional methods of macro-scale investigation.

House floors often survive as contoured surfaces on which it is possible to identify working and sleeping areas, the latter identifiable as raised 'platforms' which often have hollows moulded into them. Geochemical (phosphorus and nitrogen) and geophysical (magnetic susceptibility) sampling at $0.5 \mathrm{~m}$ intervals (illus 8) can further enhance our picture of their use, identifying high values of nitrogen, for example, in the sleeping areas and in the cooking area next to the hearth (Parker Pearson et al 2004, 70-3; see also Smith et al 2001). Flotation of floor layers in $0.5 \mathrm{~m} \times 0.5 \mathrm{~m}$ blocks (illus 9 ) also enables plotting of the spatial distribution of carbonised plant remains (seeds of cultigens and weeds, chaff, charcoal, burnt organic matter, peat) as well as of the heavy residues from flotation and the material from sieving (bone and antler fragments, tiny sherds, mould fragments, beads and small artefacts, potting clay and so on). These can be compared with the distributions of larger or complete artefacts, many of which were left on floors at abandonment.

\subsection{ABSOLUTE DATING}

Machair site sequences present problems of interpretation concerning accumulation and deflation. A deep layer of windblown sand can accumulate in a single storm whereas centuries of stratigraphic increment can similarly be destroyed in an instant. In such mercurial depositional circumstances, absolute dating becomes an essential tool, as does careful appraisal of what precisely is being dated and what formation processes it has been subjected to.

With growing awareness of the unsuitability of certain materials for radiocarbon dating (charcoal might come from ancient peat or from driftwood; anything with a substantial marine diet contains old carbon; disarticulated bones are potentially residual) so sampling has to be carefully thought out (Ashmore 1999). In our experience, carbonised seeds (from clusters of burnt grain) and articulated animal bones (with wholly or largely terrestrial diets) are the most reliable materials for dating.

In recent years, improvements in the precision of optically stimulated luminescence dating (OSL) have made it a useful method which is even better than radiocarbon dating within the first millennium $\mathrm{BC}$ (when the calibration curve is particularly flat). Jean-Luc Schwenninger's involvement in the project, initially as $\mathrm{PhD}$ student and latterly as OSL specialist, has been a major asset in this respect. Cathy Batt of Bradford University has also obtained good results from archaeomagnetic dating of hearths, despite initial pessimism from other archaeomagnetic specialists about the suitability of such deposits. Finally, new advances in extracting tephra from sand samples potentially offer a fourth means of relating sediments to dated volcanic activity (Simon Blockley, pers comm) but such approaches will need to be able to distinguish reworked layers from undisturbed ones. 


\section{DIET: RESIDUES AND ISOTOPES}

Certain scientific methods have been developed as a result of the project, either as responses to questions asked of the sites or because these sites offer a useful testing ground for the methods. A good example of the latter is the development of protein residue analysis of pot interiors (Craig et al 2000; 2005). At Cladh Hallan, Oliver Craig has extracted bovine casein (the protein in cow's milk) from the walls of about three-quarters of the sampled cooking pots. This method is very effectively used in tandem with lipid analysis and is providing a good insight into the foodstuffs boiled in prehistoric roundhouses. High lipid values just below rims (ie indicating cream settling at the top) suggest that milk was left to settle in these pots rather than being introduced as a waterproofing agent.

Oliver Craig and Jacqui Mulville have also developed a programme of stable isotope analysis $\left(\delta^{13} \mathrm{C}\right.$ and $\left.\delta^{15} \mathrm{~N}\right)$ on bones of different species to compare with levels in human bones. This has demonstrated that, despite the quantities of limpets and winkles, little marine-derived protein was being consumed by Bronze Age individuals (Parker Pearson et al in press). Analysis of strontium and oxygen isotopes in human teeth has also shown that these prehistoric Hebrideans grew up locally and that it was only in the Pictish and Norse periods that incomers are evident among the population of these islands (Montgomery et al 2003).

\subsection{INFERRING MUMMIFICATION FROM SKELETONS}

The discovery of some unusual skeletons buried as foundation deposits beneath the Cladh Hallan roundhouses has led to a programme of chemical analysis to confirm that three of these were retained long after their deaths as mummified corpses (Parker Pearson et al 2005; 2007). Mummification has not been previously recognised in prehistoric Britain and thus these finds of a woman's skeleton, a composite skeleton of three different men and a three-year-old child's skeleton are of considerable interest. Radiocarbon dating established that the bodies were much older than their context of deposition. Analysis of the bones by mercury porosimetry $(\mathrm{MgP})$, short-angle X-ray scattering (SAXS) and thin section microscopy have revealed that processes of bodily decay were interrupted and halted soon after death. Fourier-transform infra-red spectroscopy (FTIR) has also identified a demineralised surface layer on the bones, which suggests that the corpses were preserved by short-term soaking in peat (Parker Pearson et al 2005). The new suite of methods offers the possibility of examining other suspected examples of prehistoric mummification from Britain and elsewhere. 


\section{PRIORITIES FOR THE FUTURE}

The SEARCH project and its successors are currently winding down but fieldwork still continues and there are still research objectives which have yet to be met. At Howmore, Andrew Reynolds and John Raven have been investigating the island's ecclesiastical history. On Cill Donnain machair, Early Bronze Age settlements and monuments provide an important prehistoric landscape which requires further investigation. ARCUS (Archaeological Research Consultancy, University of Sheffield) has excavated remains of Neolithic and probably Mesolithic activity in advance of a road improvement scheme at the base of Bharpha Langass in North Uist. Another Neolithic settlement at An Dorlinn near Orosay in South Uist has been exposed by winter storms and requires excavation before it is washed away. There are also priorities for future management and public involvement as well as research:

1. Rabbit damage has to be controlled if not curtailed throughout the islands. Overshadowed by recent wildlife concerns about the impact of hedgehogs on bird populations, rabbits are causing long-term and systematic damage to stratified settlement mounds on a scale which will render most of these sites archaeologically useless (except for those, such as Cladh Hallan, that are deeply buried beneath windblown sand) within this century if not very soon.

2. After Ritchie's pioneering work on machair formation in the $1970 \mathrm{~s}$, relatively little has been done to date the spread of machair across the west coast of the Uists. Its progress in the last 5,000 years, covering the coastal plain and infilling freshwater lochs, could be easily tracked with a well-targeted programme of sampling and dating of machair sands and associated sediments.

3. Major events of deposition of blown sand can be dated by OSL, both within settlements and elsewhere on the machair. The current framework (Gilbertson et al 1999) can be tested through a wider systematic study.

4. The SEARCH project and subsequent studies have made relatively little impact on our knowledge of early prehistoric settlement. It seems unlikely that the Beaker-period settlements sit on top of Late Neolithic occupation sites in a manner similar to that at Northton on Harris, given the great depth of machair sand in these localities. On the other hand, pre-Beaker settlements are more likely to be found off the machair on the blacklands (where the Neolithic chambered cairns are located) and further work is required in these landscapes to provide a complete sequence of island history from the Mesolithic onwards.

5. Beaker-period and Early to Middle Bronze Age settlement mounds are a high priority for further research. It is highly likely that the earliest use of Beaker pottery in Britain (c 2600-2500 BC) predated its appearance in burials (2400-1700 BC) and thus the settlement sequences of the Western Isles may provide evidence of this earliest horizon of use. Even in the light of excavations at Northton (Harris), Dalmore (Lewis) and Rosinish (Benbecula), we still know little about domestic use of space in this period or about other aspects of social and economic life. Pottery styles such as Cordoned Urns (c 2100-1600 BC) are mostly known from their funerary contexts, and this is an opportunity to study their use in domestic settings. The Middle Bronze Age is also the period when mummification and curation of preserved corpses was practised (Parker Pearson et al 2005; 2007), and we need to shed light on how this was effected in daily life. On Cill Donnain machair a standing stone and a suspected stone circle (both buried beneath the sand) provide a monumental dimension to this landscape. The close spatial juxtaposition of stone monument(s) and settlements at Cill Donnain provides an important opportunity to explore this landscape in more detail.

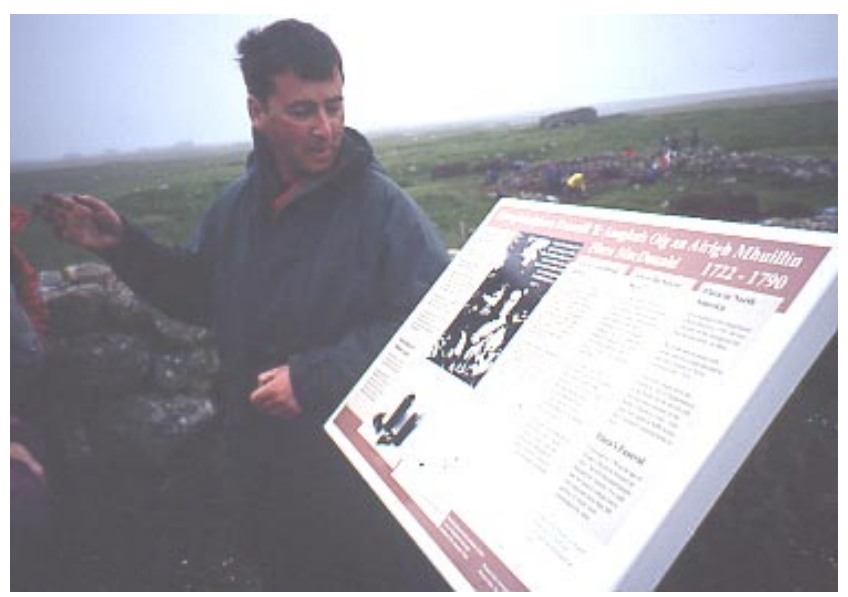

Illus 10 Jim Symonds and the information board at the Flora MacDonald Birthplace, Airigh Mhuillin. 
6. Popular involvement in presenting and visiting archaeological sites and exhibitions is growing strongly (illus 10). The new extension at Kildonan Museum and the new Barra heritage centre provide foci for interest among locals and visitors. An on-site display is planned for Cladh Hallan and there are further plans for better presentation of Dun
Vulan and the Cille Pheadair wheelhouse site. Conservation of stone buildings on the machair, with their sand mantles removed, is a difficult and expensive option, but there is great public interest in making more of these structures visible and visitable, as has been shown in Shetland at Old Scatness (Shetland Amenity Trust 2007). 


\section{ACKNOWLEDGEMENTS}

There are many people who have made this such an enjoyable project, both archaeologists and local residents. We thank Keith Branigan for compiling the SEARCH bibliography, and for long-term encour- agement during the project's running. Thanks also to other contributors at the Edinburgh seminar for their stimulating discussion; rarely has sand been more interesting! 


\section{REFERENCES}

Ashmore, P J, 1999 'Radiocarbon dating: avoiding errors by avoiding mixed samples'. Antiquity 73: 124-30.

Barber, J 2003 Bronze Age Farms and Iron Age Farm Mounds of the Outer Hebrides. Edinburgh (= Scottish Archaeological Internet Reports, 4: http:/www.sair.org.uk).

Branigan, K \& Foster, P 1995 Barra: The Archaeology of Ben Tangaval. Sheffield: Sheffield Academic Press.

Brayshay, B \& Edwards, K 1996 'Late-glacial and Holocene vegetational history of South Uist and Barra' in D Gilbertson, M Kent, \& J P Grattan (eds) The Outer Hebrides: The Last 14,000 years, 13-26. Sheffield: Sheffield Academic Press.

Caird, J B 1979 'Land use in the Uists since 1800', Proc Royal Soc Edinburgh 77B, 505-26.

Craig, O, Mulville, J, Parker Pearson, M, Sokol, R, Gelsthorpe, K, Stacey, R \& Collins, M J 2000 'Detecting milk proteins in ancient pots', Nature 408, 312 .

Craig, O, Taylor, G, Mulville, J, Collins, M J \& Parker Pearson, M 2005 'The identification of prehistoric dairying activities in the Western Isles of Scotland: an integrated biomolecular approach', J Archaeol Sci 52, 91-103.

Crawford, I A 1978 'Archaeological prospect and practical technique in an environmental region: the Western Isles machairs', World Archaeol 10, $51-62$.

Crawford, I A 1986 The West Highlands and Islands: A View of 50 Centuries. The Udal (North Uist) Evidence. Cambridge: Great Auk.

Crawford, I A \& Switsur, V R 1977 'Sand-scaping and C14: the Udal, North Uist', Antiquity 51, 124-36.

Fairhurst, H 1971 'The wheelhouse site A'Cheardach Bheag on Drimore Machair, South Uist', Glasgow Archaeol J 2, 72-106.

Gilbertson, D D, Schwenninger, J-L, Kemp, R A \& Rhodes, E A 1999 'Sand-drift and soil formation along an exposed North Atlantic coastline: 14,000 years of diverse geomorphological, climatic and human impacts', J Archaeol Sci 26, 439-469.

Hamilton, M A \& Sharples, N 1996 'A geophysical survey at Bornish, South Uist, Outer Hebrides', 1996. Specialist Report No 2, Cardiff Studies in Archaeology.

Hudson, G 1991 'Geomorphology and soils of the Outer Hebrides', in R J Pankhurst \& J M Mullin (eds), Flora of the Outer Hebrides, 19-27. London: Natural History Museum.

Lethbridge, T C 1952 'Excavations at Kilpheder, South Uist, and the problem of the brochs and wheel-houses', Proc Pre Soc 18, 176-193.
Maclaren,A1974 'A Norse house on Drimore machair, South Uist', Glasgow Archaeol J 3, 9-18.

Montgomery, J, Evans, J A \& Neighbour, T 2003 'Sr isotope evidence for population movement within the Hebridean Norse community of NW Scotland', J Geol Soc 160, 649-53.

Mulville, J, Parker Pearson, M, Sharples, N, Smith, H \& Chamberlain, A T 2003 'Quarters, arcs and squares: human and animal remains in the Hebridean Late Iron Age', in Downes, J \& Ritchie, A (eds) Sea Change: Orkney and Northern Europe in the Later Iron Age. 20-34. Balgarvies: Pinkfoot Press.

Parker Pearson, M 1996a 'South Uist machair archaeological survey and management project 1993-1996'. Unpublished report, Dept of Archaeology \& Prehistory, University of Sheffield.

Parker Pearson, M 1996b 'Two thousand years on the same land', British Archaeol 12, 7.

Parker Pearson, M \& Sharples, N with Mulville, J \& Smith, H 1999 Between Land and Sea: excavations at Dun Vulan, South Uist. Sheffield: Sheffield Academic Press.

Parker Pearson, M 2003 'Cill Donnain and Cille Pheadair', Discovery Excav Scot 4, 133.

Parker Pearson, M \& Seddon, K 2004 'Cill Donnain', Discovery Excav Scot 5.

Parker Pearson, M, Sharples, N \& Symonds, J with Mulville, J, Raven, J, Smith, H \& Woolf, A 2004 South Uist: Archaeology and History of a Hebridean Island. Stroud: Tempus.

Parker Pearson, M, Chamberlain, A T, Collins, M J, Craig, O E, Marshall, P, Mulville, J, Smith, H, Chenery, C, Cook, G, Craig, G, Evans, J, Hiller, J, Montgomery, J, Schwenninger, J-L, Taylor, G \& Wess, T 2005 'Evidence for mummification in prehistoric Britain', Antiquity 79, 529-46.

Parker Pearson, M, Chamberlain, A T, Collins, M J, Cox, C, Craig, G, Craig, O E, Hiller, J, Marshall, P, Mulville, J \& Smith, H 2007 'Further evidence for mummification in Bronze Age Britain', Antiquity 81 (http://www.antiquity. ac.uk/ProjGall/parker/index.html).

Raven, J A, 2005 Medieval Landscapes and Lordship in South Uist. PhD thesis, University of Glasgow.

Ritchie, W 1979 'Machair development and chronology in the Uists and adjacent islands', Proc Royal Soc Edinburgh 77B, 107-122.

Sellers, W I \& Chamberlain, A T 1999 ‘Ground penetrating radar survey of a Late Bronze Age archaeological site at Cladh Hallan, South Uist, Hebrides'. Report to NERC on work conducted under NERC-GEP Equipment Loan 624.

Sharples, N 1999 'The Iron Age and Norse settle- 
ment at Bornish, South Uist: an interim report on the 1999 excavations', Specialist Report No 16, Cardiff Studies in Archaeology.

Sharples, N 2004 'Life histories and the buildings of the Atlantic Iron Age', in V Turner (ed) Tall Stories? Broch studies past, present and future. Oxford: Oxbow.

Shetland Amenity Trust 2007 'Old Scatness and Jarlshof Environs Project' (http://www.bradford. ac.uk/archsci/depart/resgrp/northisles/scatness. php).

Smith, H 1996 'An investigation of site formation processes on a traditional Hebridean farmstead using environmental and geoarchaeological techniques' in D Gilbertson, M Kent, \& J D Grattan (eds) The Outer Hebrides: The Last 14,000 years, 195-206. Sheffield: Sheffield Academic Press.

Smith, H, Marshall, P \& Parker Pearson, M 2001 'Reconstructing house activity areas', in Albarella, U (ed) Environmental Archaeology: Meaning and Purpose, 249-70. London: Kluwer.

Young, A \& Richardson, K M 1960 'A'Cheardach Mhor, Drimore, South Uist', Proc Soc Antiq Scot 93, 135-173. 


\section{A BIBLIOGRAPHY OF THE 'SEARCH' PROJECT}

\subsection{MONOGRAPHS}

Branigan, K 2005 From Clan to Clearance: History and Archaeology on the Isle of Barra c 850-1850 $A D$. Oxford: Oxbow

Branigan, K \& Foster, P 1995 Barra: The Archaeology of Ben Tangaval. Sheffield: Sheffield Academic Press.

Branigan, K \& Foster, P 2000 From Barra to Berneray: Archaeological Survey and Excavation in the Southern Isles of the Outer Hebrides. Sheffield: Sheffield Academic Press.

Gilbertson, D, Kent, M \& Grattan, J P (eds) 1996 The Outer Hebrides: the last 14,000 years. Sheffield: Sheffield Academic Press.

Parker Pearson, M \& Sharples, N with Mulville, J \& Smith, H 1999 Between Land and Sea: excavations at Dun Vulan, South Uist. Sheffield: Sheffield Academic Press.

Parker Pearson, M \& Smith, H (eds) In preparation From the Machair to the Mountains: archaeological survey and excavation on South Uist. Oxford: Oxbow.

Parker Pearson, M, Smith, H \& Mulville J In preparation Cille Pheadair: A Norse-period farmstead on South Uist. Oxford: Oxbow.

Parker Pearson, M, Mulville, J, Smith, H \& Marshall, $\mathrm{P}$ In preparation Cladh Hallan: roundhouses, burial and mummification in later prehistory. Oxford: Oxbow.

Sharples, N (ed) 2005 A Norse Farmstead at Bornais, South Uist. Volume 1: Mound 3. Oxford: Oxbow.

Sharples, N (ed) In preparation A Norse Farmstead at Bornais, South Uist. Volume 3: Mound 2/2A archaeology; Volume 4: Mound 2/2A finds; Volume 5: Mound 2/2A environment. Oxford: Oxbow.

\subsection{BOOKS (POPULAR ACCOUNTS)}

Branigan, K \& Foster, P 2002 Barra and the Bishops Isles: Life on the Margin. Stroud: Tempus.

Parker Pearson, M, Sharples, N \& Symonds, J with Mulville, J, Raven, J, Smith, H \& Woolf, A 2004 South Uist: Archaeology and History of a Hebridean Island. Stroud: Tempus.

\subsection{ACADEMIC PUBLISHED PAPERS}

\subsubsection{Archaeology}

Branigan, K 1989 'Tangaval peninsula', Discovery Excav Scot, 68-9.
Branigan, K 1990 'Historical archaeology and migration: Barra blackhouse abandonment and mid-19th century migration to Nova Scotia', in M Harper \& M Vance (eds) Myth, Migration and the Making of Memory, 127-40. Edinburgh: John Donald.

Branigan, K 1991 'Brevig/Castlebay to Tangusdale', Discovery Excav Scot, 75-6.

Branigan, K 1992 'Southern Vatersay and Barra', Discovery Excav Scot, 87-8.

Branigan, K 1994 'Borve site B54', Discovery Excav Scot, 94.

Branigan, K 2003 'Assessment survey: Isle of Barra', in $\mathrm{T}$ Dawson (ed) Coastal Archaeology and Erosion in Scotland, 67-76. Edinburgh: Historic Scotland.

Branigan, K, Edwards, K \& Merrony, C, 2002 'Bronze Age fuel: the oldest direct evidence for deep peat cutting and stack construction?', Antiquity 76, 849-55.

Branigan, K \& Merrony, C 2000 'The Hebridean blackhouse in the Isle of Barra', Scottish Arch, $22,1-16$.

Cummings, V, Henley, C \& Sharples, N 2005 'The chambered cairns of South Uist', in V Cummings \& A Pannett (eds) Set in Stone: New Approaches to Neolithic Monuments in Scotland, 37-54. Oxford: Oxbow.

Cummings, V \& Sharples, N 1999 'Leaval', Discovery Excav Scot, 93.

Cummings, V \& Sharples, N In press 'The excavation of a chambered cairn at Leaval, South Uist', in V Cummings \& A Pannett (eds) Set in Stone: New Approaches to Neolithic Monuments in Scotland, 63-67. Oxford: Oxbow.

Craig, O, Taylor, G, Mulville, J, Collins, M J \& Parker Pearson, M 2005 'The identification of prehistoric dairying activities in the Western Isles of Scotland: an integrated biomolecular approach', J Archaeol Sci 52, 91-103.

Craig, O, Mulville, J, Parker Pearson, M, Sokol, R, Gelsthorpe, K, Stacey, R \& Collins, M J 2000 'Detecting milk proteins in ancient pots', Nature 408, 312 .

Fleming, A 1992 'Gearraidh Bhailteas, Kildonan', Discovery Excav Scot, 88.

Fleming, A \& Woolf, A 1992 'Cill Donnain: A Late Norse Church in South Uist', Proc Soc Antiq Scot 122, 329-50.

Foster, P 1989 'Allt Chrisal', Discovery Excav Scot, 69.

Foster, P 1991 'Sandray', Discovery Excav Scot, 75

Foster, P 1992 'Berneray and Allt Chrisal', Discovery Excav Scot, 88. 
Marshall, P, Mulville, J, Parker Pearson, M, Smith, H \& Ingrem, C 1999 'Cladh Hallan', Discovery Excav Scot 1999, 91-3.

Moreland, J 1992 'Kirkidale, South Locheynort', Discovery Excav Scot 1992, 88.

Moreland, J 1993 'Kirkidale, Loch Eynort', Discovery Excav Scot 1993, 113.

Moth, E 1989 'Cladh Hallan', Discovery Excav Scot $1989,70$.

Mulville, J 2002 'The role of cetacea in prehistoric and historic Atlantic Scotland', Int $J$ Osteoarchaeology 12, 34-48.

Mulville, J, Parker Pearson, M, Sharples, N, Smith, H \& Chamberlain, A T 2003 'Quarters, arcs and squares: human and animal remains in the Hebridean Late Iron Age', in J Downes \& A Ritchie (eds) Sea Change: Orkney and Northern Europe in the Later Iron Age AD 300-800. 20-34. Balgarvies: Pinkfoot Press.

Mulville, J \& Toms, J 2004 'Animals and ambiguity in the Iron Age of the Western Isles', in V Turner (ed) Tall Stories? Broch studies past, present and future. Oxford: Oxbow.

Parker Pearson, M 1993 'Dun Vulan, South Uist', Discovery Excav Scot 1993, 113-14.

Parker Pearson, M 1996a 'South Uist machair archaeological survey and management project 1993-1996'. Unpublished report, Dept of Archaeology \& Prehistory, University of Sheffield.

Parker Pearson, M 1996b 'Two thousand years on the same land', British Archaeol 12, 7.

Parker Pearson, M 1999 'Cosmology and architecture in Iron Age Britain', in F Braemer, S Cleuziou \& A Coudart (eds) Habitat et Société: XIXe rencontres internationales d'archéologie et d'histoire d'Antibes, 53-66. Antibes: Éditions APDCA.

Parker Pearson, M 2003 'Cill Donnain and Cille Pheadair', Discovery Excav Scot 4, 133.

Parker Pearson, M 2004 'Island prehistories: a view of Orkney from South Uist', in J Cherry, C Scarre \& S Shennan (eds) Explaining Social Change: Studies in Honour of Colin Renfrew. 127-40. Cambridge: McDonald Institute.

Parker Pearson, M, Atkinson, S, Mulville, J, Sharples, N, Smith, H \& Brennand, M 1996 'Cladh Hallan, Dun Vulan, Cille Pheadair, and South Uist machair', Discovery Excav Scot 1996, 108-10.

Parker Pearson, M, Brennand, M, Smith, H, Chamberlain, A, Marshall, P, Mulville, J \& Gidlow, J 1998 'Aisgernis, Cille Pheadair, Cladh Hallan, Frobost and Upper Loch Bornish', Discovery Excav Scot 1998, 101-105.

Parker Pearson, M, Chamberlain, A T, Collins, M J, Craig, O E, Marshall, P, Mulville, J, Smith, H, Chenery, C, Cook, G, Craig, G, Evans, J, Hiller, J, Montgomery, J, Schwenninger, J-L, Taylor, G, Wess, T 2005 'Evidence for mummification in prehistoric Britain', Antiquity 79, 529-46.

Parker Pearson, M, Chamberlain, A T, Collins, M J, Cox, C, Craig, G, Craig, O E, Hiller, J, Marshall,
P, Mulville, J \& Smith, H 2007 'Further evidence for mummification in Bronze Age Britain', Antiquity 81 (http://www.antiquity. ac.uk/ProjGall/parker/index.html).

Parker Pearson, M, Marshall, P, Mulville, J \& Smith, H 1999 'Life on the floor: a remarkable roundhouse on South Uist', Past 33, 7-8.

Parker Pearson, M, Marshall, P, Mulville, J, \& Smith, H 2000 'Cladh Hallan, South Uist', Discovery Excav Scot 1, 97-9.

Parker Pearson, M, Marshall, P, Mulville, J \& Smith, H 2000 'Scotland's earliest terraced houses', Scottish Archaeol News 32, 8-9.

Parker Pearson, M, Marshall, P, Mulville, J, \& Smith, H 2001 'Cladh Hallan, South Uist', Discovery Excav Scot 2, 102-04.

Parker Pearson, M, Mulville, J, Sharples, N \& Smith, H 2001 'Decoding dirt and deposition: the Iron Age broch settlement of Dun Vulan, Outer Hebrides, Scotland', in J Collis (ed) Society and Settlement in Iron Age Europe 125-35. Sheffield: $\mathrm{J} R$ Collis Publications.

Parker Pearson, M, Marshall, P, Mulville, J \& Smith, H 2002 'The dead beneath their feet: housewarming c $1000 \mathrm{BC}$ - roundhouse rituals at Cladh Hallan', Past 40, 1-2.

Parker Pearson, M, Mulville, J \& Smith, H 2002 'Cladh Hallan, South Uist', Discovery Excav Scot 3, 121-2.

Parker Pearson, M, Ramilisonina 2004 'Public archaeology and indigenous communities', in N Merriman (ed) Public Archaeology, 224-39. London: Routledge.

Parker Pearson, M, Seddon, K 2004 'Cill Donnain', Discovery Excav Scot 5.

Parker Pearson, M, Sharples, N 1995 'Investigating structured deposition: the Iron Age broch of Dun Vulan, Outer Hebrides', Past 19, 1-3.

Parker Pearson, M, Sharples, N, Mulville, J 1996 'Brochs and Iron Age society: a reappraisal', Antiquity 70, 57-67.

Parker Pearson, M, Sharples, N, Mulville, J 1999 'Dun Vulan: a correction', Antiquity 73, 149-52.

Parker Pearson, M, Sharples, N, Webster, J, Roper, T, Smith, H \& Mulville, J 1995 'Cill Donnain, Bornish Mounds 2 and 3, Bornish House, Dun Vulan, Cladh Hallan, and South Uist machair', Discovery Excav Scot 1995, 108-10.

Parker Pearson, M, Smith, H, Mulville, J \& Brennand, M 2004 'Cille Pheadair: the life and times of a Norse-period farmstead c 1000 1300', in J Hines, A Lane, M Redknap (eds) Land, Sea and Home, 235-54. Leeds: Maney Publishing.

Parker Pearson, M, Smith, H, Mulville, J, Brennand, M In press 'A Norse-period farmstead at Cille Pheadair, South Uist, c 1020-1220', in Batey, C $\&$ MacLeod, M (eds) Vikings in the Western Isles. Oxford: Oxbow.

Raven, J 2003 'South Uist landscapes', Discovery Excav Scot 4, 133-35.

Raven, J, Reynolds, A 2004 'Structural survey at 
Howmore, South Uist, Outer Hebrides 2003', Soc Medieval Arch Newsletter 30, 5-6.

Raven, J, Shelley, M 2003 'South Uist and Benbecula duns', Discovery Excav Scot 4, 135-37.

Sharples, N 1997 'Bornish', Discovery Excav Scot, 84-5.

Sharples, N 1998 ‘Sligenach, Cill Donnain’, Discovery Excav Scot, 104-05.

Sharples, N 1999 'Bornais', Discovery Excav Scot, 90-91.

Sharples, N 2000 'Bornish', Discovery Excav Scot 1, 96-97.

Sharples, N 2003 'From brochs to brooches: changing social relationships in the first millennium AD', in J Downes, A Ritchie (eds) Sea Change: Orkney and northern Europe in the later Iron Age $A D$ 300-AD 800, 151-68. Balgarvies: Pinkfoot Press.

Sharples, N 2004 'Life histories and the buildings of the Atlantic Iron Age', in V Turner (ed) Tall Stories? Broch Studies Past Present and Future. Oxford: Oxbow.

Sharples, N 2004 'A find of Ringerike art from Bornais in the Outer Hebrides', in J Hines, A Lane \& M Redknap (eds) Land, Sea and Home, 255-72. Leeds: Maney Publishing.

Sharples, N In press 'Bornais: an early historic and Norse settlement on South Uist', in C Batey \& M MacLeod (eds) Vikings in the Western Isles. Oxford: Oxbow.

Sharples, N \& Hamilton, M 1996 ‘Bornish', Discovery Excav Scot 1996, 108

Sharples, N \& Parker Pearson, M 1997 'Why were brochs built? Recent studies in the Iron Age of Atlantic Scotland', in A Gwilt, C Hazelgrove (eds) Reconstructing Iron Age Societies, 254-265. Oxford: Oxbow.

Sharples, N \& Parker Pearson, M 1999 'Norse settlement in the Outer Hebrides', Norwegian Archaeol Rev 32, 41-62.

Sharples, N, Parker Pearson, M, Symonds, J 2004 'The archaeological landscape of South Uist', in R A Housley, G Coles (eds) Atlantic Connections and Adaptations: economies, environments and subsistence in lands bordering the North Atlantic, 28-47. Oxford: Oxbow.

Smith, H, Marshall, P, Parker Pearson, M 2001 'Reconstructing house activity areas', in U Albarella (ed) Environmental Archaeology: meaning and purpose, 249-70. London: Kluwer.

Smith, H, Mulville, J 2004 'Resource management in the Outer Hebrides: an assessment of the faunal and floral evidence from archaeological investigations', in R A Housley, G Coles (eds) Atlantic Connections and Adaptations: economies, environments and subsistence in lands bordering the North Atlantic, 48-64. Oxford: Oxbow.

Symonds, J 1996 ‘Airigh Mhuilinn', Discovery Excav Scot 1996, 107.

Symonds, J 2003 'An imperial people: highland Scots and the British imperial world', in S Lawrence (ed) Archaeologies of the British: explorations of identity in Great Britain and its colonies 16001945, 138-56. London: Routledge.

Symonds, J, 2000 'The dark island revisited: an approach to the historical archaeology of Milton, South Uist', in J A Atkinson, I Banks, G MacGregor (eds) Townships to Farmsteads: rural settlement studies in Scotland, England and Wales, 196-209. Oxford: BAR British Series (= Brit Archaeol Rep Brit Ser, 293).

Symonds, J 1999 'Toiling in the vale of tears: everyday life and resistance in South Uist, Outer Hebrides, 1760-1860', Int J Historical Archaeol $3,101-121$.

Symonds, J 1999 'Songs remembered in exile? Integrating unsung archives of highland life', in A Gazinch-Schwartz, C Holtorf (eds) Folklore and Archaeology, 106-28. London: Routledge.

Symonds, J 1999 'Surveying the remains of a highland myth: investigations at the birthplace of Flora MacDonald, Airigh Mhuillin, South Uist', in M Harper, M E Vance (eds) Myth, Migration and the Making of Memory: Scotia and Nova Scotia c 1700-1990, 73-88. Halifax, Edinburgh: Fernwood Publishing, John Donald.

Symonds, J, Badcock, A 2000 'Airigh Mhuillin', Discovery Excav Scot 1, 96.

Symonds, J, Badcock, A, Klemperer, M, Beaudry, M, Brighton, S 1998 'Gearraidh Bhailteas and Milton House', Discovery Excav Scot 1998, 104.

Symonds, J, Lund, J, Warren, G 1998 'Airigh Mhuillin', Discovery Excav Scot 1998, 101.

Williams, G, Sharples, N 2003 'Et nytt myntfunn fra Olav Kyrre fra Hebridene', Nordisk Numismatisk Unions Medlemsblad 3-4, 55-56.

Zvelebil, M 1989 'South Uist midden', Discovery Excav Scot 1989, 69-70.

Zvelebil, M 1991 'Kildonan', Discovery Excav Scot 1991, 75.

\subsubsection{Palaeoecology}

Ashmore, P, Brayshay, B A, Edwards, K J, Gilbertson, D D, Grattan, J P, Kent, M, Pratt, K M, Weaver, R E 2000 'Allochthonous and autochthonous mire deposits in relation to slope instability: palaeoenvironmental investigations in the Borve Valley, Barra, Outer Hebrides, Scotland', The Holocene 10, 97-108.

Brayshay, B A, Gilbertson, D D, Kent, M, Edwards, K J, Wathern, P, Weaver, R E 2000 'Surface pollen-vegetation relationships on the Atlantic seaboard: South Uist, Scotland', J Biogeography 27, 359-378.

Charman, D J, Grattan, J P 1999 'An assessment of discriminant function analysis in the identification and correlation of distal Icelandic tephras in the British Isles', in Firth, C R, McGuire W $\mathrm{J}$ (eds) Volcanoes in the Quaternary. Geological Society, London, Special Publication, 161, 147-160. 
Charman, D J, Grattan, J P, West, S, Kelly, A 1995 'Environmental response to tephra deposition in the Strath of Kildonan, northern Scotland', $J$ Archaeol Sci 22, 799-809.

Dinnin, M, Sadler, J P 1999 ‘10,000 years of change: the Holocene entomofauna of the British Isles', Quaternary Proceedings 7, 545-562.

Dodgshon, R A, Grattan, J P, Gilbertson, D D 2000 'Farming, endemic stress and the impacts of Icelandic volcanic eruptions in Scotland', in W McGuire, D R Griffiths, P L Hancock, I S Stewart (eds) The Archaeology of Geological Catastrophes. Geological Society, London, Special Publication 171, 267-280.

Dugmore, A J, Newton, A J, Edwards, K J, Larsen, G, Blackford, J J, Cook, G T 1997 'Long-distance marker horizons from small-scale eruptions: British tephra deposits from the $\mathrm{AD} 1510$ eruption of Hekla, Iceland', J Quaternary Sci 11, 511-516.

Edwards, K J 1996 'A Mesolithic of the Western and Northern Isles of Scotland? Evidence from pollen and charcoal', in T Pollard, A Morrison (eds) The Early Prehistory of Scotland, 23-38. Edinburgh: EUP.

Edwards, K J 2000 'Pollen, archaeology, and burdens of proof', in R Young (ed) Mesolithic lifeways: current research from Britain and Ireland, 67-74. Leicester: Leicester Archaeology Monographs.

Edwards, K J 2003 'What landscape means to me', Landscapes 4, 111-115.

Edwards, K J 2004 'Palaeoenvironments of Late Upper Palaeolithic and Mesolithic Scotland and the North Sea area: new work, new thoughts', in A Saville (ed) Mesolithic Scotland: the early Holocene prehistory of Scotland and its European context, 55-72. Edinburgh: Soc Antiq Scot.

Edwards, K J 2004 'People, environmental impacts, and the changing landscapes of Neolithic and Early Bronze Age times', in I Shepherd, G Barclay (eds) Scotland in ancient Europe: the Neolithic and Early Bronze Age of Scotland in their European context, 55-69. Edinburgh: Soc Antiq Scot.

Edwards, K J, Buckland, P C, Blackford, J J, Dugmore, A J, Sadler, J P 1994 'The impact of tephra: proximal and distal studies of Icelandic eruptions', Münchener Geographische Abhandlungen, 133-145.

Edwards, K J, Mulder, Y, Lomax, T A, Whittington, G, Hirons, K R 2000 'Human-environment interactions in prehistoric landscapes: the example of the Outer Hebrides', in D Hooke (ed) Landscape, The Richest Historical Record. Society for Landscape Studies Supplementary Series, 1, 13-32.

Edwards, K J, Smout, T C 2000 'Setting the scene: perspectives on human-environment interactions in prehistoric and historical times', in G Holmes, R Crofts (eds) Scotland's Environment: the Future, 3-29. Edinburgh: Tuckwell Press in association with Royal Soc Edinburgh, Scottish Natural Heritage.
Edwards, K J, Sugden, H 2003 'Palynological visibility and the Mesolithic colonization of the Hebrides, Scotland', in L Larsson, H Kindgren, K Knutsson, D Loeffler, A Akerlund (eds) Mesolithic on the move. 11-19. Oxford: Oxbow.

Edwards, K J, Whittington, G 1994 'Lateglacial pollen sites in the Western Isles of Scotland', Scottish Geog Mag 110, 33-39.

Edwards, K J, Whittington, G 2001 'Lake sediments, erosion and landscape change during the Holocene in Britain and Ireland', Catena 42, 143-173.

Edwards, K J, Whittington, G, Hirons, K R 1995 'The relationship between fire and long-term wet heath development in South Uist, Outer Hebrides, Scotland', in D B A Thompson, A J Hestor, M B Usher (eds) Heaths and moorlands: cultural landscapes, 240-248. Edinburgh: HMSO.

Edwards, K J, Whittington, G, Ritchie, W In press 'The possible role of humans in the early stages of machair evolution: palaeoenvironmental investigations in the Outer Hebrides, Scotland', J Archaeol Sci.

Edwards, K J, Whittington, G, Tipping, R 2000 'The incidence of microscopic charcoal in late glacial deposits', Palaeogeography, Palaeoclimatology, Palaeoecology 164, 263-278.

Fieller, N R J 1993 'Archæostatistics: old statistics in ancient contexts', The Statistician 42, 279-295.

Fieller, N R J, Flenley, E C 1988 'Statistical analysis of particle sizes and sediments', Computer Applications in Archaeology 15, 79-94. Oxford: BAR Int Series (= Brit Archaeol Rep Int Series, 393).

Fieller, N R J, Flenley, E C, Olbricht, W 1992 'Statistics of particle size data', Applied Statistics 41, 127-146.

Gearey, B, Gilbertson, D D 1997 'Pollen taphonomy of trees in a windy climate: Northbay Plantation, Barra, Outer Hebrides', Scottish Geog Mag 113, 113-120.

Gilbertson, D D, Kent, M 1997 'The machair grasslands of the Outer Hebrides: a biological and cultural heritage', in E Apicella (ed) Il Sistema Uomo-Ambiente Tra Passato E Presente. 125136. Ravello: Centro Universitario Europeo Pre I Beni Culturali.

Gilbertson, D D, Kent, M, Schwenninger, J-L, Wathern, PA, Weaver, R, Brayshay, B A 1995 'The machair vegetation of Scotland: its interacting ecological, geomorphic and historical dimensions', in R A Butlin, N Roberts (eds) Human Impact and Adaptation: Ecological Relations in Historical Times, 17-44. Oxford: Blackwell.

Gilbertson, D D, Powers, A H, Padmore, J A, Flenley, E C, Fieller, N R J 1992 'The analogue approach to reconstructing prehistoric environments: the analysis of ancient human environments using statistical comparisons of the physical and biological properties of sediments', in M Bernardi, (ed) L'Archaeologia del Paesaggio, 165-203. Firenze: Consiglio Nazionale della Richerche.

Gilbertson, D D, Schwenninger, J-L, Kemp, R A, 
Rhodes, E A 1999 'Sand-drift and soil formation along an exposed North Atlantic coastline: 14,000 years of diverse geomorphological, climatic and human impacts', J Archaeol Sci 26, 439-469.

Grattan, J P 1994 'Land abandonment and Icelandic volcanic eruptions in the late 2nd Millennium BC', Münchener Geographische Abhandlungen B12, 111-132.

Grattan, J P 1998 'The response of marginal societies and ecosystems in Britain to Icelandic Volcanic eruptions', in Mills, C M, Coles, G (eds) Life on the Edge: Human Settlement and Marginality. 21-30. Oxford: Oxbow.

Grattan, J P, Briggs, D, Durand, M, Gilbertson, D D, Pyatt, F B, Taylor, S 2001 'Pronounced human mortality events co-incident with volcanogenic air pollution', Geophysical Research Abstracts 3, 257.

Grattan, J P, Gilbertson, D D 1994 'Acid-loading from Icelandic tephra falling on acidified ecosystems as the key to settlement abandonment and environmental stress in northern and western Britain', J Archaeol Sci 21, 851-859.

Grattan, J P, Gilbertson, D D 1994 'Icelandic volcanic eruptions, acid precipitation, and the "settlement crisis" in northern Britain in the Late Bronze Age', Geological Soc America Bulletin 26, 264.

Grattan, J P, Gilbertson, D D 2000 'Prehistoric "settlement crisis" and environmental changes in the British Isles and volcanic eruptions in Iceland: an exploration of plausible linkages', in $\mathrm{F}$ W McCoy, G Heiken (eds) Volcanic Hazards and Disasters in Human Antiquity, 33-42. Boulder: Geological Society of America.

Grattan, J P, Gilbertson, D D, Charman, D 1997 'Man, settlement, environment and the potential role of volcanically-generated acid volatiles in the "upland crisis" of the European Late Bronze Age', in E Apicella (ed) Il Sistema Uomo-Ambiente Tra Passato E Presente, 167-180. Ravello: Centro Universitario Europeo Pre I Beni Culturali.

Grattan, J P, Gilbertson, D D, Charman, D 1999 'Modelling the impact of Icelandic eruptions upon the prehistoric societies and environments of northern and western Britain', in C R Firth, W McGuire (eds) Volcanoes in the Quaternary. 109-124. Oxford: Blackwell, Geological Society of London.

Kent, M, Gilbertson, D, Andrews, M 2003 'Storminess in palaeoclimatic change: the potential of intertidal and littoral shellfish as indicators of changing storm conditions and intensity', in $\mathrm{C}$ Albore-Livadie, F Ortolani (eds) Climatic-Environmental variations and impact on Man in the circum Mediterranean area during the Holocene, 193-201. Bari: Centro Universitario Europeo Per I Beni Culturali.

Powers, A H, Gilbertson, D D 1987 ‘A simple preparation technique for the extraction of opal phytoliths from archaeological and Quaternary sediments', J Archaeol Sci 14, 529-535.

Powers, A H, Padmore, J A, Gilbertson, D D 1989
'Studies of late prehistoric and modern opal phytoliths from coastal sand dunes and machair in northwest Britain', J Archaeol Sci $16,27-43$.

Pyatt, F B, Grattan, J P 2003 'Fen and loch sediment geochemistry: climatic and environmental changes over 12,000 years on the western seaboard of Britain - EDMA approaches and solutions', in C Albore-Livadie, F Ortolani (eds) Climatic-Environmental variations and impact on Man in the circum Mediterranean area during the Holocene. 203-214. Bari: Centro Universitario Europeo Per I Beni Culturali.

Pyatt, F B, Grattan J P, Lacy, D, Gilbertson, D D, Brayshay, B A, Wadsworth, W 1995 'Exploratory studies of loch-sediment chemistry and soil history in a 10,000+ year old core from Loch Hellisdale, South Uist, Outer Hebrides', Scottish Geog Mag 111, 106-112.

Ritchie, W, Whittington, G, Edwards, K J 2001 'Holocene changes in the physiography and vegetation of the Atlantic littoral of the Uists, Outer Hebrides, Scotland', Trans Royal Soc Edinburgh: Earth Sciences 92, 121-136.

Smith, D N 1996 'Thatch, turves and floor deposits: a survey of Coleoptera in materials from abandoned Hebridean blackhouses and the implications for their visibility in the archaeological record', J Archaeol Sci 23, 161-74.

Whittington, G, Edwards, K J 1997 'Evolution of a machair landscape: pollen and related studies from Benbecula, Outer Hebrides, Scotland', Trans Royal Soc Edinburgh: Earth Sciences 87, 515-531.

Whittington, G, Edwards, K J 2000 'Illecebrum verticillatum L in the Outer Hebrides', Botanical $J$ Scotland 52, 101-104.

\subsubsection{Ecology}

Kent, M, Brayshay, B A, Gilbertson, D D, Wathern, P A, Weaver, R 1994 'A biogeographical study of plant communities and environmental gradients on South Uist, Outer Hebrides, Scotland', Scottish Geog Mag 10, 85-99.

Kent, M, Dargie, T C, Reid, C 2003 'The management and conservation of machair vegetation', Botanical J Scotland 55, 161-176.

Kent, M, Owen, N, Dale, P 2005 In press 'Photosynthetic responses of a plant community to sand burial on the machair dune systems of the Outer Hebrides, Scotland', Annals of Botany.

Kent, M, Owen, N, Dale, P, Newnham, R, Giles, T 2001 'Studies of vegetation burial: a focus for biogeography and biogeomorphology?', Progress in Physical Geography 25, 455-482.

Owen, N, Kent, M, Dale, P 2000 'The ecological effects of cultivation on the machair sand dune SSSI, Outer Hebrides, Scotland', J Coastal Conservation 6, 155-170.

Owen, N, Kent, M, Dale, P 2001 ‘'Spatial and temporal 
variability in seed dynamics of machair sand dune plant communities, the Outer Hebrides, Scotland', J Biogeography 28, 565-588.

Owen, N, Kent, M, Dale, P 2004 'Species and community responses to sand burial on the machair sand dune systems of the Outer Hebrides', J Vegetation Sci 15, 669-678.

Owen, N, Kent, M, Dale, M P, Ramsay, P 1998 'The vegetation of Kildonan machair, South Uist, Outer Hebrides', Scottish Geog Mag 114, 34-41.

Pyatt, F B, Gilbertson, D D 1998 'An Atlantic shoreline ecosystem recovering from Chernobyl (?) Gamma-radioactivity: Isle of Barra, Western Isles, Scotland', Environmental Management and Health 2/3, 54-59.

Pyatt, F B, Gilbertson, D and Grattan, J P 1998 'Accumulation of $\lambda$-radioactivity in inter-tidal and terrestrial ecosystems on the Island of Mingulay, Western Isles, Scotland, UK', Fresenius Environmental Bulletin 7, 327-33.

\subsection{POPULAR ACCOUNTS (NOT INCLUDING NEWSPAPER} REPORTS)

Anon 2004 'Spor etter Hebridenes Vikinger: velhavende vikinger kan ha slått seg opp på sildefiske', Levande Historie 6, 8.

Branigan, K 1989 'Barra', Current Archaeology 113, 182-3.

Branigan, K 1989 'Mankind on the margin', Archaeology $1989,58-59$.

Branigan, K 1991 'Fly into history on Barra', Flightpath 1991, 6-9.

Branigan, K 1994 'The giant cists of Glen Bretadale, Barra', Armchair Anthropologist 1, 6-12.

Branigan, K 1997 'Mankind on the margin', Curr Archaeol 152, 284-9.

Branigan, K 1997 'The Isle of Barra: clearance and emigration 1800-1851', Naidheachd a'Chlachain 4, 10-18.

Branigan, K 2002 'From Barra to Nova Scotia', Naidheachd a'Chlachain 8, 26.

Branigan, K 2004 'With the crofters to Canada', History Today 54, 41-47.

Evans, J and Montgomery, J 2004 'Slaves, Vikings and mummies', Geoscientist 14 (8), 4-7.

Fleming, A 1993 The Cill Donnain Archaeology and Wildlife Trail. Cill Donnain: Kildonan Museum.

Keys, D 2001 'The mummies of Cladh Hallan', BBC History (http://www bbc co uk/history/archaeology/mummies_cladhhallan_01 shtml).

Keys, D 2003 'The secret of Cladh Hallan', Geographical Magazine 75, 38-43

Keys, D 2003 'Europe's oldest mummies', Archaeology 56 (5), 16-17.

October Films 2003 The Mummies of Cladh Hallan. BBC2 Meet the Ancestors television documentary.

Parker Pearson, M 1996 'Sheffield University on South Uist and Barra', Archaeology in the Hebrides: An t-Earrach 1996, 6.
Parker Pearson, M In press 'Cladh Hallan, Cille Pheadair and Bornais, South Uist', Curr Archaeol.

Pitts, M 2002a 'Iron Age bodies buried under houses', BBC History Magazine, April 2002.

Pitts, M 2002b 'Cladh Hallan', Current Archaeology 179,455 .

Selkirk, A, Parker Pearson, M 1997 'Dun Vulan', Curr Archaeol 152, 293-301.

Schwald, R 2005 'The mummies of Cladh Hallan', Welt der Wunder. Munich: German Television

Sharples, N 2000 'In SEARCH of an ancient past', Historic Scotland Membership Magazine (winter section) 30-32.

Sharples, N 2004 'Bornish', Scottish Archaeological News 46, 1-3.

Symonds, J 1997 'The Flora MacDonald Project', Curr Archaeol 152, 304-307.

Symonds, J 2001 'South Uist: an island story', Curr Archaeol 175, 276-280.

Thompson, S 2003 'Europe's oldest mummies (so far) found in UK', National Geographic Kids Magazine 12.

Young, E 2000 'Perfect porridge', New Scientist (http://www newscientist com/news/news jsp?id=ns9999175).

\subsection{UNPUBLISHED REPORTS (NOT INCLUDING MSC AND PHD THESES)}

SEARCH interim reports 1-12 (1988-1999) Department of Archaeology, Prehistory, University of Sheffield

Atkinson, S, Mulville, J, Parker Pearson, M 1996 'The Late Bronze Age and Early Iron Age settlement at Cladh Hallan, South Uist: excavations in 1996', Department of Archaeology, Prehistory, University of Sheffield.

Branigan, K, Grattan, J P 1998 'Coastal Assessment Survey: Barra and Vatersay', Department of Archaeology, Prehistory, University of Sheffield.

Branigan, K 2000 'The Buaile-nam-Bodach Project', Department of Archaeology, Prehistory, University of Sheffield.

Brennand, M, Parker Pearson, M, Smith, H 1998 'The Viking Age settlement at Kilpheder (Cille Pheadair), South Uist: excavations in 1998', Department of Archaeology, Prehistory, University of Sheffield.

Brennand, M, Parker Pearson, M, Smith, H 1997 'The Viking Age settlement at Kilpheder (Cille Pheadair), South Uist: excavations in 1997', Department of Archaeology, Prehistory, University of Sheffield.

Cummings, V, Sharples, N 1999 'The excavation of a chambered cairn at Leaval, South Uist', Specialist Report No. 17, Cardiff Studies in Archaeology.

Hamilton, M A, Sharples, N 1996 'A geophysical survey at Bornish, South Uist, Outer Hebrides, 1996', Specialist Report No. 2, Cardiff Studies in Archaeology. 
Henley, C 2000 'Loch a'Choire, South Uist: excavation and survey June 2000', Specialist Report No. 21, Cardiff Studies in Archaeology.

Marshall, P, Mulville, J, Parker Pearson, M \& Smith, H 1999 'A Late Bronze Age/Early Iron Age community at Cladh Hallan, South Uist: excavations 1999', Department of Archaeology, Prehistory, University of Sheffield.

Marshall, P, Mulville, J, Parker Pearson, M, Gidlow, J 1998 'A Late Bronze Age/Early Iron Age settlement and Early Bronze Age occupation at Cladh Hallan, South Uist: excavations in 1998', Department of Archaeology, Prehistory, University of Sheffield.

Marshall, P, Parker Pearson, M 1997 'The Iron Age dun in Upper Loch Bornish, South Uist: excavations in 1997', Department of Archaeology, Prehistory, University of Sheffield.

Marshall, P, Mulville, J, Parker Pearson, M 1996 'Beinn na Mhic Aongheis: Hill of the Son of Angus: excavation of Bornish Site 89, South Uist 1996', Department of Archaeology, Prehistory, University of Sheffield.

Mulville, J, Parker Pearson, M 1997 'A Late Bronze Age/Early Iron Age roundhouse at Cladh Hallan, South Uist: excavations in 1997', Department of Archaeology, Prehistory, University of Sheffield.

Mulville, J, Parker Pearson, M 1995 'The Late Bronze Age/Earliest Iron Age house at Cladh Hallan, South Uist: excavations in 1995', Department of Archaeology, Prehistory, University of Sheffield.

Parker Pearson, M, Marshall, P, Mulville, J, Smith, H 2002 'Cladh Hallan: excavation of a Later Bronze Age to Early Iron Age settlement and cemetery, August-September 2002', Department of Archaeology, Prehistory, University of Sheffield.

Parker Pearson, M, Marshall, P, Mulville, J, Smith, H 2001 'Cladh Hallan: excavation of a Late Bronze Age to Early Iron Age settlement, AugustSeptember 2001', Department of Archaeology, Prehistory, University of Sheffield.

Parker Pearson, M, Marshall, P, Mulville, J, Smith, H, Ingrem, C 2000 'Cladh Hallan: excavation of a Late Bronze Age to Early Iron Age settlement, August-September 2000', Department of Archaeology, Prehistory, University of Sheffield.

Parker Pearson, M 1996 'South Uist machair archaeological survey and management project 1993-1996', Department of Archaeology, Prehistory, University of Sheffield.

Parker Pearson, M, Brennand, M, Smith, H 1996 'Sithean Biorach, Cille Pheadair: Fairy Point, Kilpheder: excavations of a Norse period settlement on South Uist', Department of Archaeology, Prehistory, University of Sheffield.

Parker Pearson, M 1995 'Cill Donnain, South Uist: excavations of a Late Norse church site in the Western Isles', Department of Archaeology, Prehistory, University of Sheffield.

Parker Pearson, M 1995 'South Uist machair archaeological survey and management project
1993-1995', Department of Archaeology, Prehistory, University of Sheffield.

Parker Pearson, M, Roper, T 1995 'Excavations at Bornish House, South Uist, Western Isles', Department of Archaeology, Prehistory, University of Sheffield.

Parker Pearson, M, Sharples, N 1995 'Dun Vulan excavations 1995, South Uist, Western Isles', Department of Archaeology, Prehistory, University of Sheffield.

Parker Pearson, M, Roper, T 1994 'Cladh Hallan, South Uist, Western Isles: Late Bronze Age/ Earliest Iron Age house and Late Bronze Age midden', Department of Archaeology, Prehistory, University of Sheffield.

Parker Pearson, M, Webster, J 1994 'Bornish Mound 2 Viking-age settlement: 1994 excavations: interim report', Department of Archaeology, Prehistory, University of Sheffield.

Parker Pearson, M 1993 'Dun Vulan, South Uist, Western Isles: an interim report of the 1993 excavations', Department of Archaeology, Prehistory, University of Sheffield.

Parker Pearson, M, Sharples, N 1992 'Dun Vulan, South Uist, Western Isles: an interim report of the 1992 excavations', Department of Archaeology, Prehistory, University of Sheffield.

Parker Pearson, M, Sharples, N 1991 'Dun Vulan, Bornish, South Uist', Department of Archaeology, Prehistory, University of Sheffield.

Sellers, W I, Chamberlain, A T 1999 'Ground penetrating radar survey of a Late Bronze Age archaeological site at Cladh Hallan, South Uist, Hebrides', Report to NERC on work conducted under NERC-GEP Equipment Loan 624.

Sharples, N 1996 'The Iron Age and Norse settlement at Bornish, South Uist: an interim report on the 1996 excavations', Specialist Report No. 1, Cardiff Studies in Archaeology.

Sharples, N 1997 'The Iron Age and Norse settlement at Bornish, South Uist: an interim report on the 1997 excavations', Specialist Report No. 4, Cardiff Studies in Archaeology.

Sharples, N 1998 'Excavations at Sligenach, Cill Donnain, South Uist 1998', Specialist Report No. 12, Cardiff Studies in Archaeology.

Sharples, N 1999 'The Iron Age and Norse settlement at Bornish, South Uist: an interim report on the 1999 excavations', Specialist Report No. 16, Cardiff Studies in Archaeology.

Sharples, N 2000 'The Iron Age and Norse settlement at Bornish, South Uist: an interim report on the 2000 excavations', Specialist Report No. 18, Cardiff Studies in Archaeology.

Sharples, N 2003 'The Iron Age and Norse settlement at Bornish, South Uist: an interim report on the 2003 excavations', Specialist Report, Cardiff Studies in Archaeology.

Sharples, N 2004 'The Iron Age and Norse settlement at Bornish, South Uist: an interim report on the 2004 excavations', Specialist Report, Cardiff Studies in Archaeology. 
Sharples, N, Webster, J, Parker Pearson, M 1995 'The Viking Age settlement at Bornish, South Uist: interim report of the 1995 excavations. Department of Archaeology, Prehistory, University of Sheffield.

\subsection{PHD THESES AND MA/MSC DISSERTATIONS}

Allan, L A 1988 'Geo- and bioarchaeological studies of palaeosols in the coastal dunes and machair of South Uist in the Outer Hebrides', MSc dissertation, University of Sheffield (Author's surname changed from Kennedy).

Alldritt, D 1992 'An analysis of plant macrofossils from the midden at Dun Vulan, South Uist, Outer Hebrides', MSc dissertation, University of Sheffield.

Ballantyne, R 1998 'Norse-period use of plant resources in the Outer Hebrides, and an evaluation of charred plant macro-remains as indicators of space use', MSc dissertation, University of Sheffield.

Bertzeletos, J 1994 'A palynological study of South Uist, the Outer Hebrides, Scotland', MSc dissertation, University of Sheffield.

Brayshay, B 1992 'The vegetation and vegetational history of South Uist and Barra in the Outer Hebrides', PhD thesis, University of Sheffield.

Cummins, G 1994 'Potential Mesolithic human impact and subsequent environmental change at Loch An T'Sil, South Uist, Outer Hebrides: a palynological study', MSc dissertation, University of Sheffield.

Dalton, F 1995 'An investigation into the vegetation history of the site of Reineval, South Uist, during the Mesolithic period of prehistory, using fine resolution pollen and microscopic charcoal analysis', MSc dissertation, University of Sheffield.

Dinnin, M 1992 'Islands within islands', PhD thesis, University of Sheffield.

Gearey, B 1992 'The taphonomy of pollen in a climate of extreme windiness - Barra, Outer Hebrides', MSc dissertation, University of Sheffield.

Grattan, J P 1994 'The impact of Icelandic volcanic eruptions upon the ancient settlement and environment of northern and western Britain.' PhD thesis, University of Sheffield.

Hastie, M 1998 'Look to the seeds: a Viking longhouse and two outhouses at Kilpheder, South Uist', MSc dissertation, University of Sheffield.

Henley, C 2005 'The Outer Hebrides and the Hebridean world during the Neolithic: an island history', PhD thesis, University of Cardiff.

Hutchens, E 1993 'Ants on the edge: a palaeoenvironmental investigation into two sites from the Outer Hebrides', MSc dissertation, University of Sheffield.

Kaplan, C 1998 'An archaeofaunal analysis from Kilpheder, South Uist, Outer Hebrides: the exploitation of domestic and wild animals. A self-sufficient family farmstead?', MSc dissertation, University of Sheffield.

Lloyd, R 1999 'Remains of mammalian fauna from Kilpheder, South Uist, Outer Hebrides', MSc dissertation, University of Sheffield.

McLaughlin, W 1990 'Traditional fuels of the Outer Hebrides: the modern charred seed assemblages', MSc dissertation, University of Sheffield.

Milner, E 2000 'Cille Pheadair: the application of GIS for analysing the intrasite distribution of archaeological materials', MSc dissertation, University of Bournemouth.

Mulder, Y 1992 'Two pollen diagrams from Barra, Outer Hebrides', MSc dissertation, University of Sheffield.

Mulder, Y 1999 'Aspects of vegetation and settlement history in the Outer Hebrides, Scotland', PhD thesis, University of Sheffield.

Mulville, J 1993 'Milking, herd structure and bone chemistry: an evaluation of archaeozoological methods for the recognition of dairying', $\mathrm{PhD}$ thesis, University of Sheffield.

Pelling, R 1992 'Dun Vulan, South Uist: an analysis of the charred plant remains from the chamber', MSc dissertation, University of Sheffield.

Powers, A H 1993 'Opal phytolith analysis: a tool for the investigation of prehistoric patterns of plant and land utilizations in a marginal island environment', PhD thesis, University of Sheffield.

Pratt, K 1991 'A palynological study of landscape change and human settlement in the Borve Valley, Barra', MSc dissertation, University of Sheffield.

Raven, J A, 2005 'Medieval Landscapes and Lordship in South Uist', PhD thesis, University of Glasgow.

Roper, T 1999 'A history of change: the environment and beetles of the Western Isles of Scotland', PhD thesis, University of Sheffield.

Rutherford, A 1989 'Micropalaeontological methods for the recognition of the use of seaweed as a fertiliser in historic and prehistoric coastal dune deposits on South Uist in the Outer Hebrides of Scotland', MSc dissertation, University of Sheffield.

Scales, R 2001 'The study of a prehistoric animalbone assemblage from Cladh Hallan, South Uist', MSc dissertation, University of Sheffield.

Schwenninger, J-L 1996 'The evolution of coastal sand dunes in the southern isles of the Outer Hebrides of Scotland', PhD thesis, University of London (Royal Holloway College).

Smith, D N 1988 'Fossils and modern analogue: a study of insect faunas from blackhouses on South Uist', MSc dissertation, University of Sheffield.

Smith, D N 1991 'An investigation of the potential of modern analogue faunas to act as comparisons to palaeoentomological samples from archaeological farm sites', PhD thesis, University of Sheffield.

Smith, H 1994 'Middening in the Outer Hebrides: an 
ethnoarchaeological study', $\mathrm{PhD}$ thesis, University of Sheffield.

Ul-Haq, S 1989 'Remains of mammalian fauna from Kildonan, South Uist, Outer Hebrides', MSc dissertation, University of Sheffield.

Walters, E 2000 'An analysis of the social use of space in a number of longhouses excavated at
Kilpheder (Cille Pheadair), Outer Hebrides, through palaeo-molluscan analysis', MSc dissertation, University of Bournemouth.

Ward, M 1999 'An assessment of the mammalian fauna from Kilpheder, South Uist, Outer Hebrides, Phases 7 and 8' MSc dissertation, University of Sheffield. 



\title{
Local community groups and Aeolian archaeology: shorewatch and the experience of the Shetland Community Archaeology Project
}

\author{
Tom Dawson \\ University of St Andrews, St Andrews, Fife, KY16 9AL \\ Olivia Lelong and Ingrid Shearer \\ GUARD, University of Glasgow, Gregory Building, Lilybank \\ Gardens, Glasgow, G12 8QQ
}

Scottish Archaeological Internet Report 48, 2011 www.sair.org.uk 


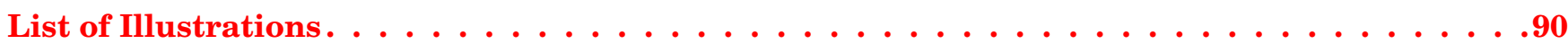

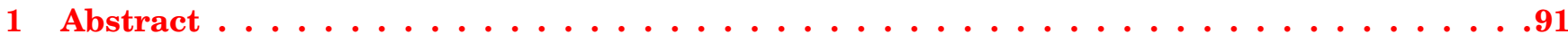

2 The Threat to Sites Buried in Aeolian Landscapes $\ldots \ldots \ldots \ldots \ldots$

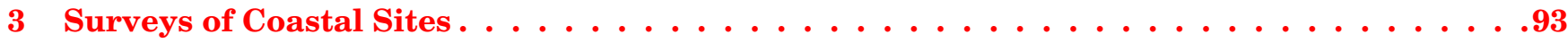

4 Shorewatch and the Role of Local Groups in Monitoring Sites in Aeolian Landscapes . . . .95

4.1 Baile Sear, North Uist . . . . . . . . . . . . . . . . . . . . . . . . . . . . . 95

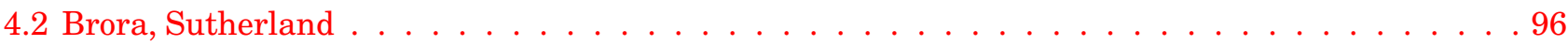

5 Community Archaeology at Sandwick, Unst, Shetland . . . . . . . . . . . . . . .98

5.1 The assessment and excavation: lessons learned . . . . . . . . . . . . . . . . 98

5.2 Training volunteers in community archaeology at Sandwick . . . . . . . . . . . . . . 101

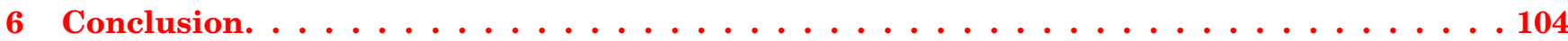

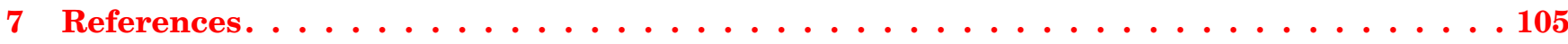




\section{LIST OF ILLUSTRATIONS}

1

2

Cille Pheadair, South Uist, A Norse structure collapsed on the beach in Feb 2005 . . . . . . . 93 Cille Pheadair, South Uist, the same structure in May 2005, covered by blown sand . . . . . . . 94 Members of Access Archaeology drawing a plan of eroding structures at Baile Sear,

North Uist . . . . . . . . . . . . . . . . . . . . . . . . . . . . . . 96 Members of the Clyne Heritage Society working at the eroding salt pans on the Back Beach, Brora . . . . . . . . . . . . . . . . . . . . . . . . . . . . . . 97 Location map of Sandwick. . . . . . . . . . . . . . . . . . . . . . . . . . 99

Plan of trench, structure and burial. . . . . . . . . . . . . . . . . . . . . . 100

Trench outline plus resistivity plot . . . . . . . . . . . . . . . . . . . . 100

Plan of the structure at earlier phase. . . . . . . . . . . . . . . . . . . . . . . . 101

Members of the local groups trowelling at Sandwick, Unst . . . . . . . . . . . . . . . . . 102 


\section{ABSTRACT}

There are hundreds of archaeological sites exposed in areas of windblown sand around Scotland. Once revealed, they are vulnerable to erosion and at risk of total destruction. Many lie in remote areas and members of local communities can play an important role in monitoring and recording such sites. This paper shows how the Shorewatch Project has involved groups across the country to work on aeolian sites. It gives details of one recent project, demonstrating how archaeologists and local group members can collaborate successfully to save information before it is lost forever. 


\section{THE THREAT TO SITES BURIED IN AEOLIAN LANDSCAPES}

Drifting sand has covered many archaeological sites, leaving them hidden from view until exposed by the action of wind, animals, the sea or humans. Some of the sites become uncovered in plan when the overlying sand is blown away. However, this can cause problems in interpretation as it is common for the wind to remove sediment from both above and beneath structures or artefacts, causing evidence representing hundreds or even thousands of years of occupation to settle together at the bottom of the resulting deflation hollow.
The result is a confusing mix of archaeological evidence and a consequent loss of information and stratigraphic integrity.

Even more damaging to archaeological remains is the erosion of the coastal edge by the sea, which can lead to the rapid destruction of a site once the soft sediment surrounding it has washed away. A combination of high tides and strong winds can cause the coast edge to retreat by tens of metres in a storm, revealing or even destroying entire sites during a single event. 


\section{SURVEYS OF COASTAL SITES}

Archaeological sites within dune systems are therefore highly vulnerable to disturbance or destruction by natural processes. As a first step to managing this threatened resource, it is necessary to map the position and condition of the remains, and Historic Scotland has sponsored a series of Coastal Zone Assessment Surveys (Dawson 2003). The surveys have built upon data gathered by the Ordnance Survey, RCAHMS, local Historic Environment Records and information collected by antiquarians such as Erskine Beveridge (Beveridge 1903 and 1911). The Coastal Zone Assessment Surveys have mapped the distribution of archaeological sites; noted the surrounding geology and geomorphology; and made an assessment of the erosional status of the coast edge. The survey reports can be downloaded from the SCAPE Trust website (www.scapetrust.org).
The surveys have been successful at locating numerous previously unrecorded sites, in some cases quadrupling the number (Brady 1998, 78; Long 1996, 89). Due to the intensive nature of the surveys and the enormous length of Scotland's coast (estimated to be $12,000 \mathrm{~km}$, but see Ashmore 2003, 216), Archaeological Procedure Paper 4: Coastal Zone Assessment Survey (Historic Scotland 1996) specified that surveys should only investigate a strip extending between 50 and $100 \mathrm{~m}$ from the coast edge. This meant that in areas of dune, only the seaward fringes were investigated.

As dunes often cover many acres of undulating land, systematic walk-over surveys are difficult and time-consuming, and large areas still await investigation. Even in areas where survey information has been gathered, it can become out of date quickly. Dune systems are highly mobile and can change with

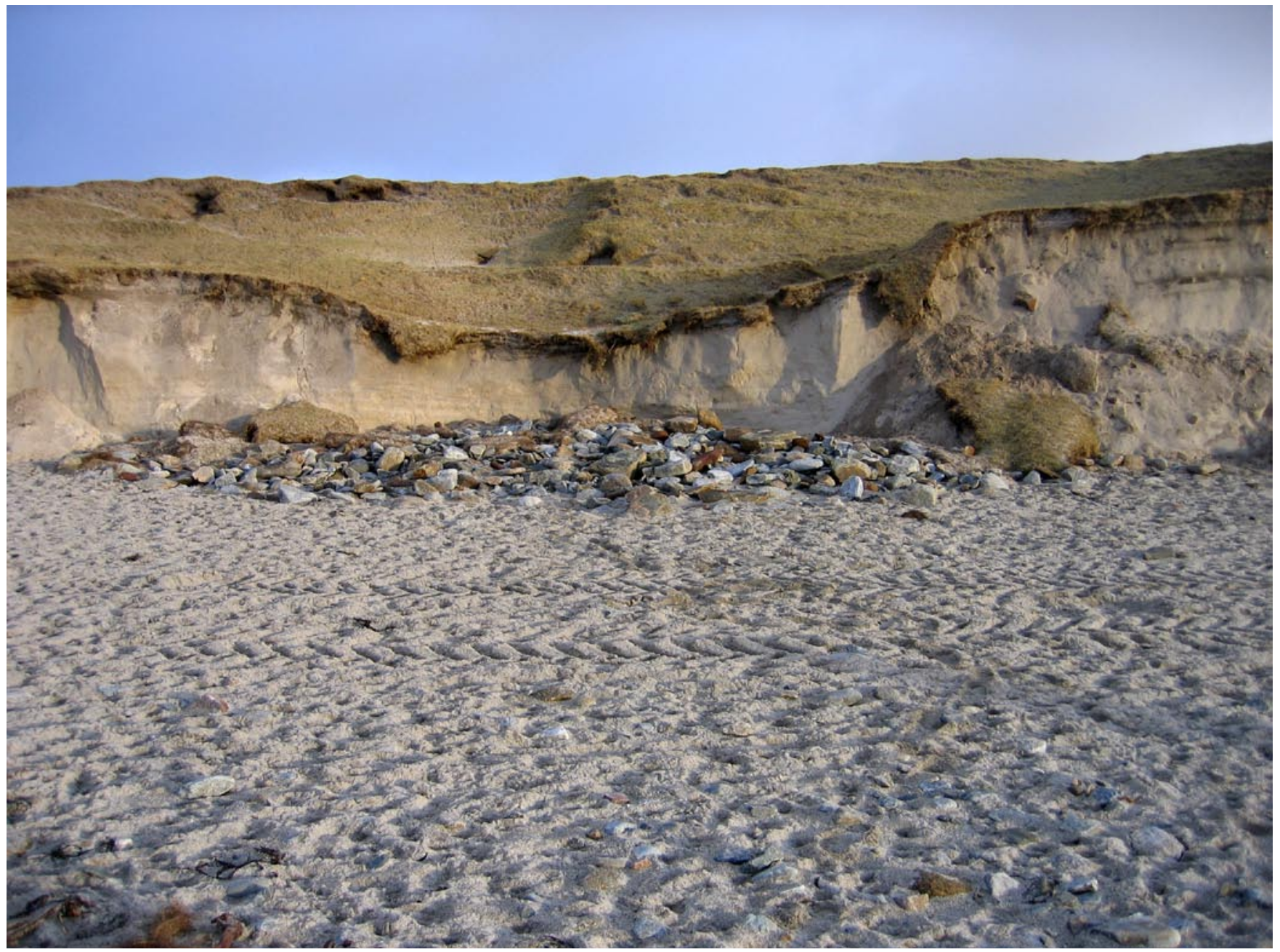

Illus 1 Cille Pheadair, South Uist, a Norse structure collapsed on the beach in Feb 2005 


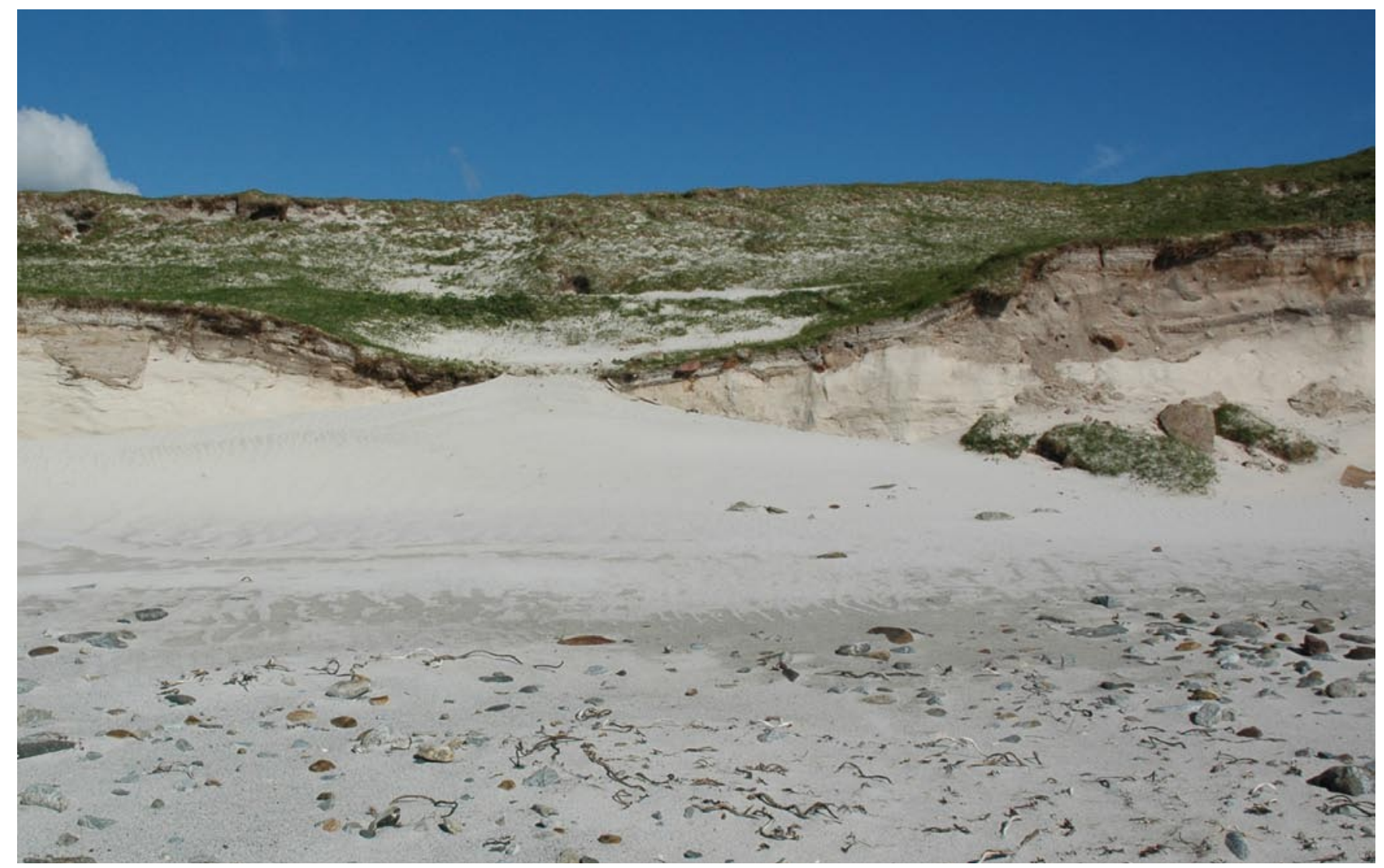

Illus 2 Cille Pheadair, South Uist, the same structure in May 2005, covered by blown sand

astounding rapidity. Exposed sites can be hidden under sand, while previously unrecorded remains can be revealed in new exposures, sometimes for very short periods (illus $1 \& 2$ ). Repeat surveys of the coast and aeolian landscapes, perhaps undertaken every five or ten years, are desirable, but overstretched budgets mean they are unlikely at the present. Remote sensing and other methods of rapidly investigating large expanses of dune, such as described by Winterbottom et al (discussed at the conference), can help in locating sites, but this needs to be followed by detailed survey and recording. 


\section{SHOREWATCH AND THE ROLE OF LOCAL GROUPS IN MONITORING SITES IN AEOLIAN LANDSCAPES}

Many people with an active interest in archaeology live and work near areas of dune, visiting them on a regular basis. With training and guidance they can be a valuable asset, helping heritage managers by discovering, recording and monitoring sites. Recognition of the value of members of local communities in coastal projects led to the formation of the Shorewatch Project, originally started as a partnership between Historic Scotland and the Council for Scottish Archaeology in 1997 (Fraser et al 2003).

Pilot Shorewatch groups were established around Scotland and members were encouraged to search for new sites, recording information which was passed on to local and national records. The groups were supplied with a Resource Pack which provided information on how to participate, including basic details on how to record sites (Gilmour 2001). The original pilot project had a part-time co-ordinator who acted as a focus and arranged classroom-based workshops.

In order to make the individual groups successful, there was a heavy reliance on a local leader, preferably a trained archaeologist, to head the group. As the Shorewatch project developed, it became evident that it wasn't always possible to find such a co-ordinator, and that the Resource Pack alone was not enough to equip group members with the skills necessary to undertake recording projects. It was decided that intensive, practical training sessions were needed to teach group members the skills necessary to record and monitor sites.

Since 2001, Shorewatch has been co-ordinated by The SCAPE Trust. Support from the Heritage Lottery Fund, Historic Scotland, The Crown Estate and the University of St Andrews has provided a full-time and part-time project officer who have been able to dedicate more time to working with the groups. Groups have been established all around the Scottish coast, and these are working in a variety of environments. However, they are not confined to the $50-100 \mathrm{~m}$ coastal strip investigated during the CZA surveys, and many groups are undertaking projects within areas of dune.

Pro forma recording sheets have been developed and modified after discussions with the curators of the National Monuments Record for Scotland. The forms adhere to standards laid out in the MIDAS Manual (RCHME 1998) and to the ASPIRE protocol (ASPIRE 2005). Equipment has been provided to groups, including hand-held GPS receivers and digital cameras. Group members are asked to take pictures from the same position and facing the same direction during each monitoring visit so that changes to sites and landscapes can be evaluated. Participants send photographs of features and artefacts to the Shorewatch project officers, allowing an initial evaluation and interpretation to be given, together with advice on further action, without the group having to disturb the site itself.

The project officers have arranged locally based training sessions where groups are taken to a site and taught survey and recording techniques. Repeat training sessions have been arranged to build skills and confidence. The project officers have helped groups plan further action at individual sites, helping them to set up more detailed recording projects. Resources have also been made available on a website dedicated to the project (www.shorewatch.co.uk).

Additional training sessions have been delivered by teams of professional archaeologists working with group members at local sites. These have either been in conjunction with Coastal Zone Assessment Surveys or as part of stand-alone projects. Between 2000 and 2004, five Coastal Zone Assessment Surveys were managed by The SCAPE Trust. The project brief for each of these included a necessity to work with Shorewatch groups. The surveys by EASE Archaeology of three Inner Hebridean islands led to the formation of groups on Coll and Islay (Moore \& Wilson 2002; 2003), and both of these groups have been active in areas of dune. Groups were also established by GUARD (Sneddon 2003) and CFA Archaeology Ltd (Cressey \& Johnson 2004, Cressey $\&$ Badger 2005) during their surveys of the Clyde Estuary.

After time spent locating and monitoring sites, many members of community groups have developed a desire to take their projects further by initiating more detailed recording projects. This is especially true in cases where the group has been monitoring an actively eroding site over a number of years and wishes to retrieve information before its total destruction. As such sites are under immediate threat, the use of local community members to record the eroding remains may be the only option for retrieving any data from it.

In 2004/05, the SCAPE Trust helped develop three pilot projects at eroding sites within aeolian environments (Baile Sear, Brora and Unst), all undertaken by local group members. In each case, the groups have recorded information that would otherwise have been lost.

\subsection{Baile Sear, North Uist}

The island of Baile Sear, North Uist, Western Isles, was severely affected by the storm of January 2005 . In places, up to 50 metres of the sandy coast edge 


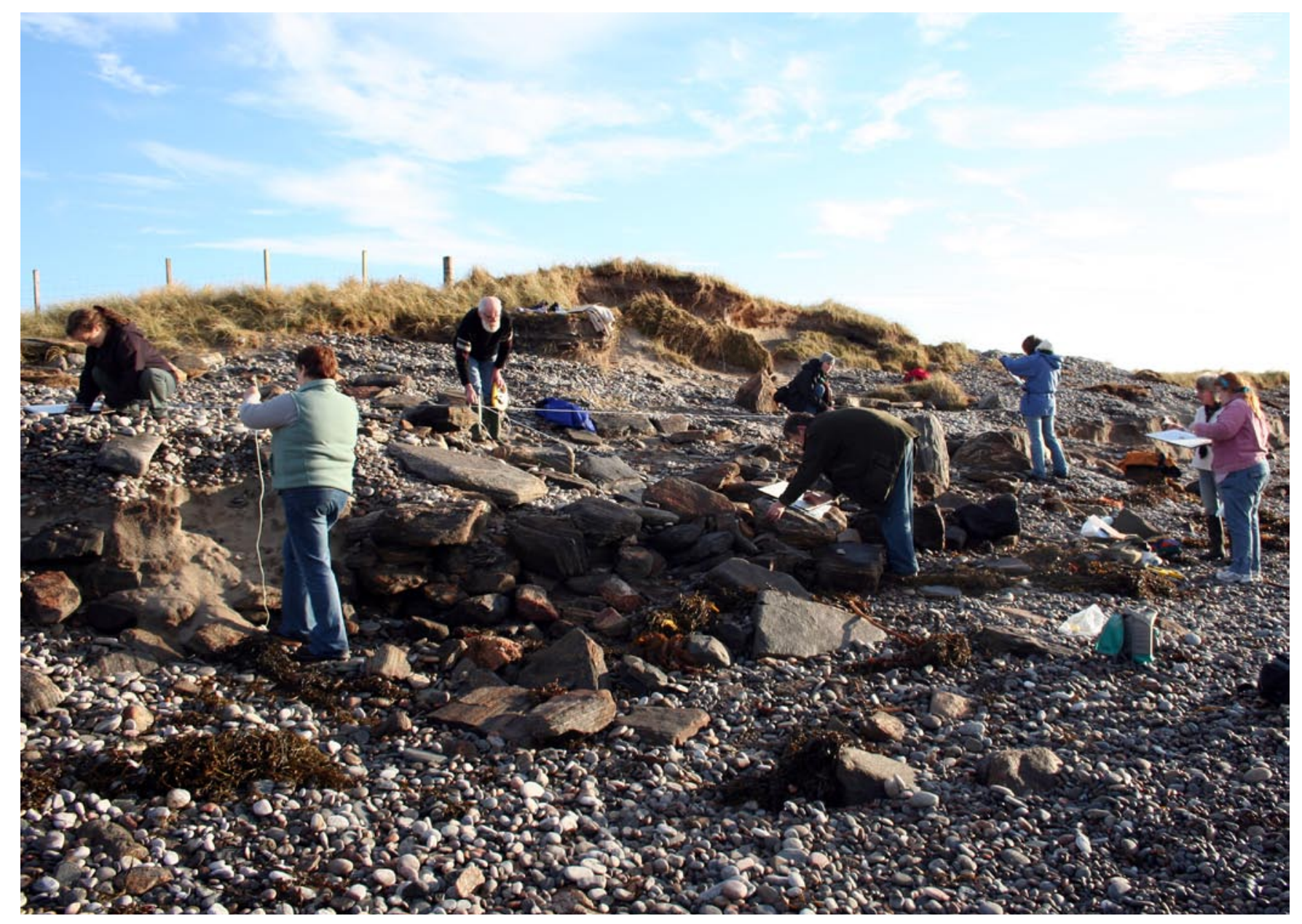

Illus 3 Members of Access Archaeology drawing a plan of eroding structures at Baile Sear, North Uist.

were washed away in a single night. Several new archaeological sites, previously hidden within the dunes, were exposed by the storm. A local group, Access Archaeology, has started to monitor these exposures (illus 3). At one site, they have drawn a series of plans and taken photographs over a period of months. They have noted structures, hearths and artefacts exposed on the beach and in the dune behind. Their work has been co-ordinated by Katinka Stentoft of The SCAPE Trust, and she has published records of their work on the Shorewatch website (www.shorewatch.co.uk/html/accessarch). The drawings reveal that between August and December 2005, up to four metres of archaeological remains were lost, and the site is continuing to erode at an alarming rate. As the sea takes away the deposits Katinka is helping the group develop plans for further action at the site.

\subsection{Brora, Sutherland}

At Brora, Sutherland, members of the Clyne Heritage Society (CHS) have been monitoring structures eroding from the dunes on the Back Beach, south of the harbour. A wall constructed of mortared ashlar blocks lies on the beach immediately in front of the dune. To the north, a second building with well-constructed masonry walls and a flagstone floor protrudes from the dune. The floor is above the present beach level and the structure has been cut in half by erosion. Between the two areas of masonry are deep deposits of burnt material, clinker and other residues.

CHS members have examined documentary evidence and have found a map, dated 1812, which depicts 'Old Salt Pans' marked at the position of the eroding structures. These salt pans were connected with evaporating sea water using coal from neighbouring pits. Records show that the 'Old Salt Pans' were constructed in 1598 but had gone out of use within a few years.

The group also found photographs and drawings of the structures made by members of the local community in the past, which they have compared with the visible remains. Today, much of the wall on the beach has collapsed and its foundations are covered by sand, but the photographs and a sketch plan show over 30 metres of the wall were standing in the 1970s. The documents demonstrate the speed 


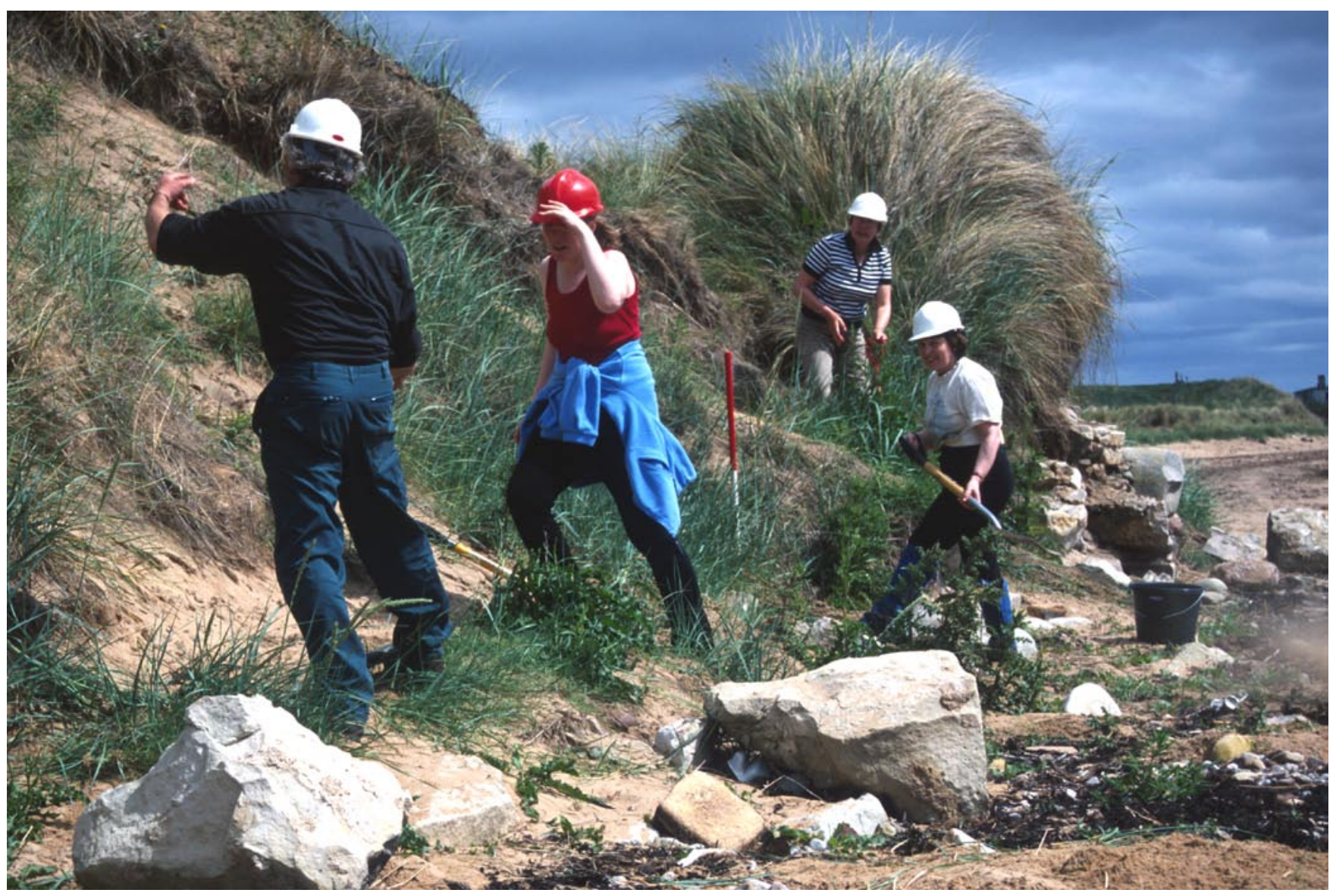

Illus 4 Members of the Clyne Heritage Society working at the eroding salt pans on the Back Beach, Brora.

with which the structures are collapsing and the urgent need to record the remains before they are lost.

The group (including members of the North of Scotland Archaeological Society) worked with staff from Highland Council's archaeology and survey departments and the Shorewatch project officers to record the extent and condition of the wall situated on the beach. This structure was chosen as it had already been disturbed by the sea and because it presented a safer working environment than the other structures revealed higher up within the dunes. Group members were able to develop simple excavation techniques within a safe environment and with minimum danger of archaeological layers being disturbed.

The aim of the project was to determine whether other parts of the building survived buried within the dune or whether it had been lost to the sea. The group members removed beach sand to reveal the top of the wall, demonstrating that much of it still survived, albeit mainly at foundation level (illus 4). They were at pains not to disturb archaeological layers, and in the doorway, after noting that some deposits remained in situ above the threshold, they immediately stopped working within that area. They made a plan of the wall, drawing it using planning frames and plotting it with a Total Station theodolite. They also surveyed the area around the structure, tying their survey into the Ordnance Survey grid and marking on the position of the coast edge and some of the adjacent bell pits from the abandoned coal mine. After the wall was fully recorded and photographed, it was re-covered.

In 2005, the group continued their investigation at the site in collaboration with CFAArchaeology. They examined the dunes using geophysical survey techniques and augers, and are currently formulating plans for further investigation and partial excavation of the most threatened structures. 


\section{COMMUNITY ARCHAEOLOGY AT SANDWICK, UNST, SHETLAND}

At Sandwick on the island of Unst, the Shetland Community Archaeology Project was instigated by SCAPE in collaboration with the Shetland Amenity Trust and their Shetland's Past project. The archaeological site consisted of a sub-circular mound at the edge of the beach, with an eroding section that revealed walling and occupation deposits (illus 5). It had first been noted by the Unst Amateur Archaeology Group and brought to the attention of Val Turner of the Shetland Amenity Trust. Glasgow University Archaeological Research Division (GUARD) were commissioned to assess the site's archaeological potential in 2004, and excavation proceeded with funding from the Heritage Lottery Fund and Historic Scotland in 2005. The project was designed both to train volunteers in how to investigate eroding coastal sites and to rescue information from the site before it was claimed by the sea.

With excavation set to proceed, at the time of writing, to a second season in 2006 , the project has already produced valuable lessons about the most effective ways to assess and excavate eroding sites and to involve volunteers in their investigation.

\subsection{The ASSESSMENT AND EXCAVATION: LESSONS LEARNED}

The assessment involved a number of different survey methods: desk-based study, walk-over survey, topographic survey, auger survey, geophysical survey, cleaning and recording of the eroding face and limited tapestry excavation (Lelong \& Shearer 2004). The volunteers assisted with and received training in each of the fieldwork elements. The deskbased assessment and walk-over survey helped to establish the character and extent of known archaeology around the eroding mound and the recent history of deflation and accretion. The research highlighted the presence of significant remains of late Norse, Pictish and possibly Viking Age date along the margins of the bay (Bigelow 1978; 1979; $1980 ; 1984 ;$ Hansen 1995). The examination of aerial photographs illuminated the highly dynamic nature of the local Aeolian landscape. The photographs showed that, 60 years before, the area around the eroding mound was largely deflated, with only the mound itself and another circular area to the SSW preserving turf cover. Over the succeeding decades, the turf cover had crept back to its present extent.

Augering over and around the eroding mound established the thickness of the windblown sand deposits and the depth at which anthropogenic soils lay. Geophysical survey, using both gradiometer and resistivity, recorded an anomaly that was interpreted as a large, sub-circular structure sealed beneath the eroding mound, with its seaward edge corresponding to the stonework revealed in section.

Investigation of the eroding face as part of the 2004 assessment involved cleaning of the section face, recording it using scaled photographs and measured drawing, and limited tapestry excavation (the vertical excavation of the site starting from the eroding face, as opposed to horizontal excavation starting from the top). Various portions of coursed and orthostatic walling were revealed, along with over a metre of stratified occupation deposits and about 70 sherds of coarse pottery.

Armed with the understanding of the site gained through the assessment, the team returned in 2005 to open a trench over the mound and excavate it from the top down. The results both proved the value of the 2004 assessment and also revealed its limitations.

The eroding mound proved to seal not a subcircular structure, but one made up of three partly truncated cells, which together formed a building that followed the arc of the shoreline (illus 6). Re-examination of the geophysical plots in combination with the trench outline (illus 7) showed that the anomaly actually corresponded to these cells. The site's interpretation as a sub-circular structure had resulted from extrapolation of the arcing anomaly, combined with surface interpretation of the mound's shape - which was itself, excavation showed, an artefact of windblown sand. The resisitivity plot also showed a high-resistance anomaly at the mound's western edge, and this proved to correspond to some large stones that lay approximately above an extended inhumation burial. The burial had been cut through the thick deposit of windblown sand that built up over the structure after its abandonment. In retrospect, the coring intervals for the auger survey (on a $10 \mathrm{~m}$ grid) were too coarse to allow informed interpretation of what lay beneath the windblown sand. A much denser grid of cores over the mound would have permitted more accurate prediction of the site's character and extent (although it would also have damaged archaeological deposits to a greater degree).

The structure itself consisted of three cells (illus 8) (Lelong \& Shearer 2005). Based on the results so far, the walls - which stand up to $1.5 \mathrm{~m}$ high in places - partly collapsed in later prehistory; subsequently, the cells saw another phase of use among the ruins. This post-collapse phase left behind a series of hearth and midden deposits in structure 1 and heaps of bog iron or iron-working slag and peat ash in structure 2. Hundreds of sherds of coarse pottery and pieces of animal bone were scattered in 

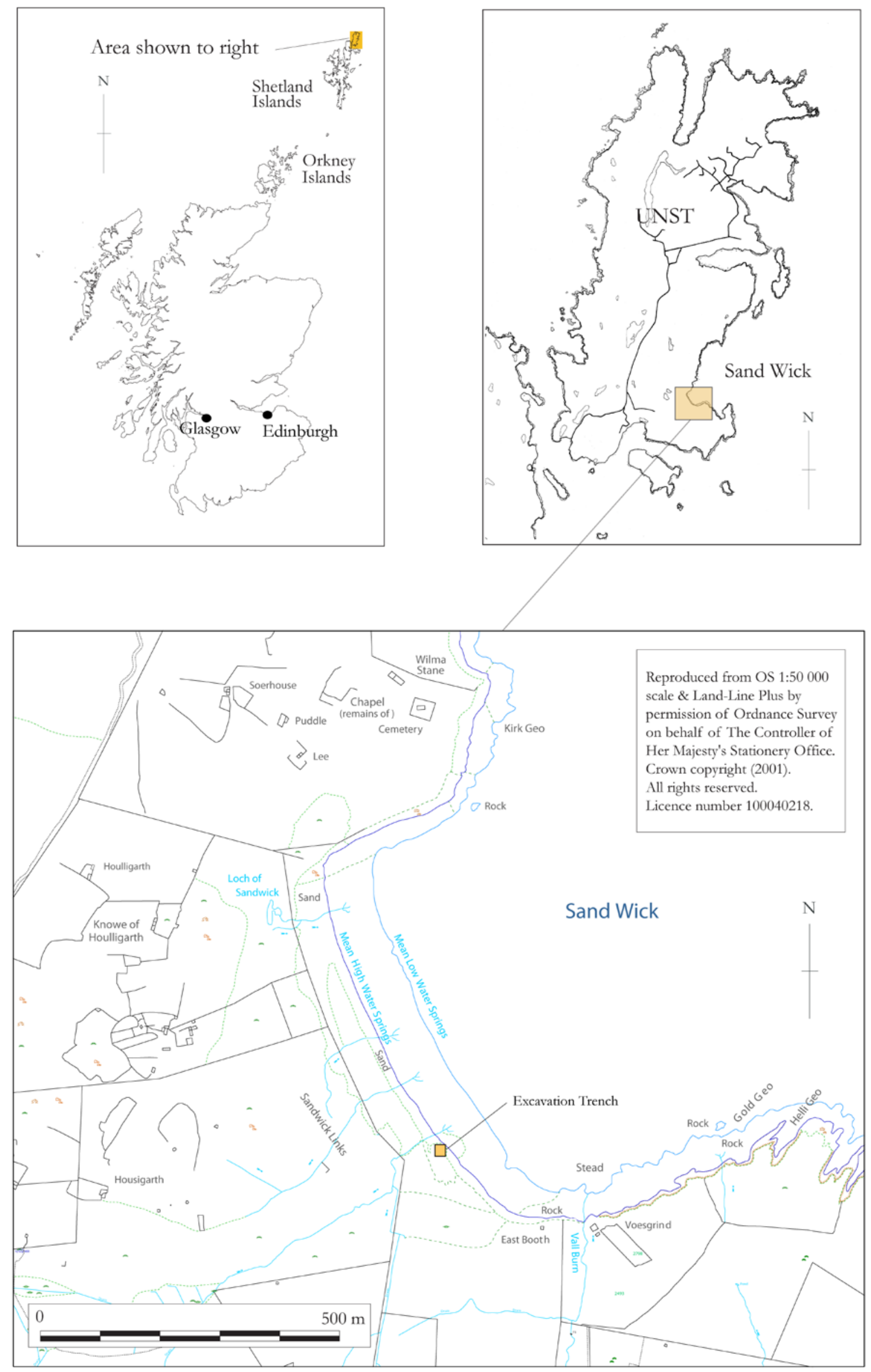

Illus 5: Location map of Sandwick 


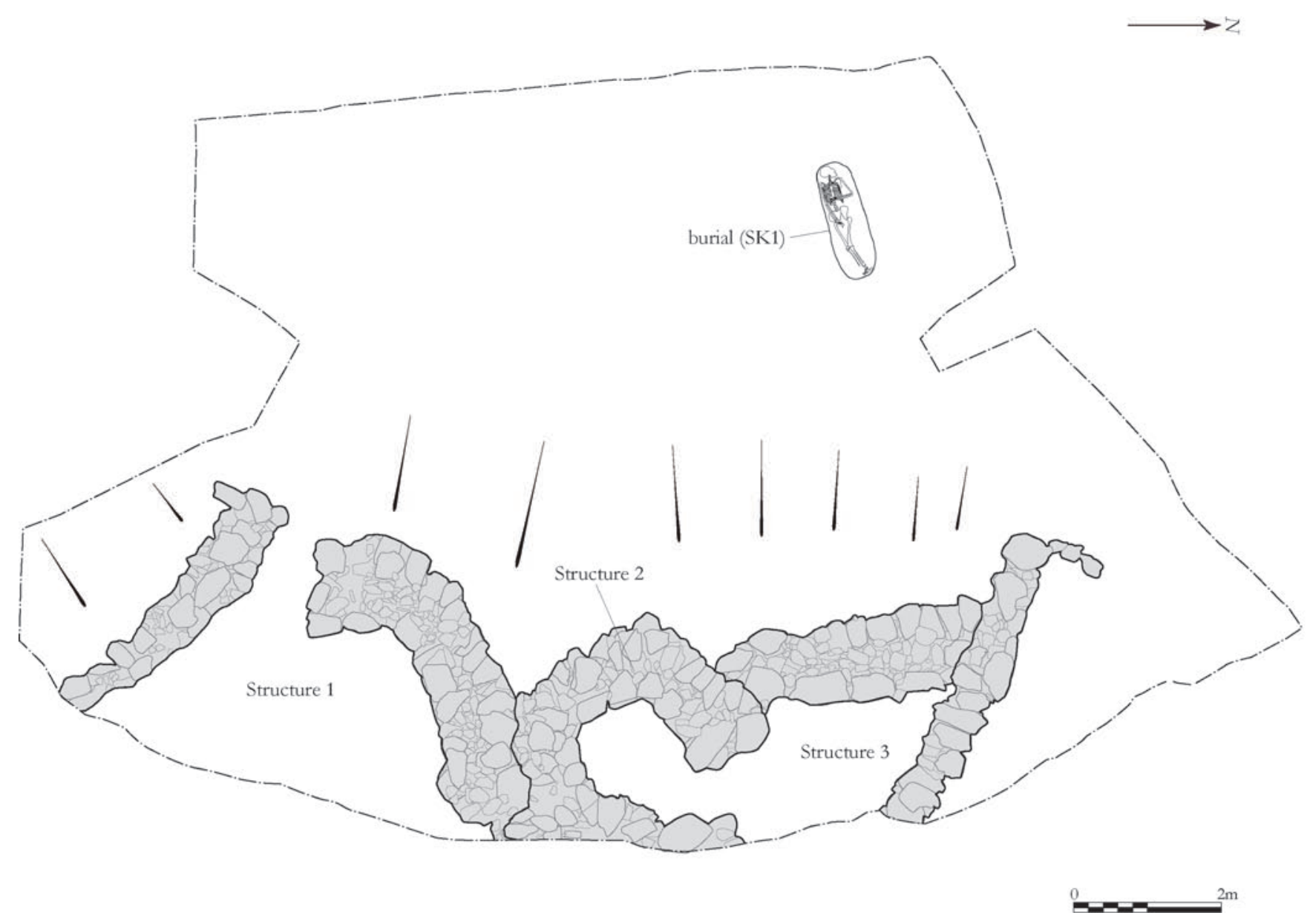

Illus 6 Plan of trench, structure and burial

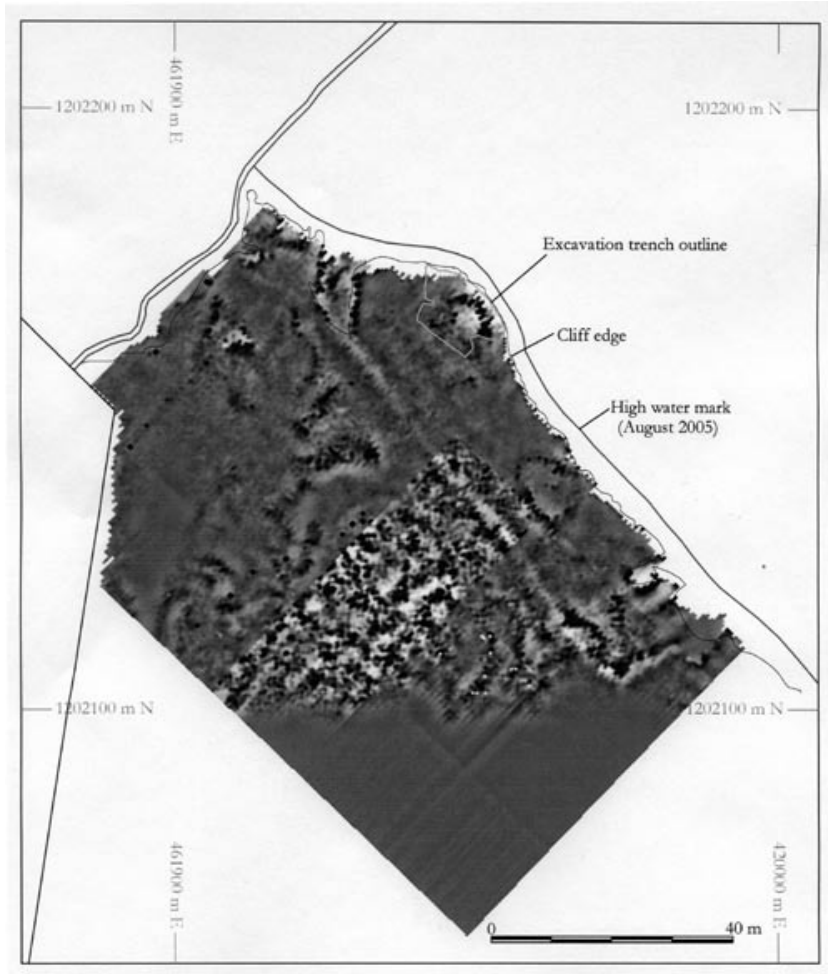

Illus 7 Trench outline plus resistivity plot and around the building during this phase. Later, the local environment seems to have become much windier, as a sandier midden deposit built up inside the cells and partly over the walls. Later still the wind must have increased dramatically or changed direction, and a thick layer of clean windblown sand sealed the whole building and its environs. The burial, which was accompanied by a polished stone disc of probable late Iron Age date, was cut into this layer.

Comparing the excavation results with the assessment results reveals both the value and the drawbacks of section cleaning and tapestry excavation. These aspects of the assessment did provide some idea of the stonework's character and the depth and complexity of the stratigraphic sequence. If the site had been investigated wholly through tapestry excavation, digging $0.5 \mathrm{~m}$ back from the section face, this method would have revealed the following: the eroded eastern ends of the walls defining structures 1,2 and 3; a small portion of the trampled occupation and post-abandonment midden deposits in all three cells, including the hearth deposits in structure 1 , and perhaps also the relationship between structures 1 and 2. It would, however, have provided no evidence of the shape and size of the cells, of the 


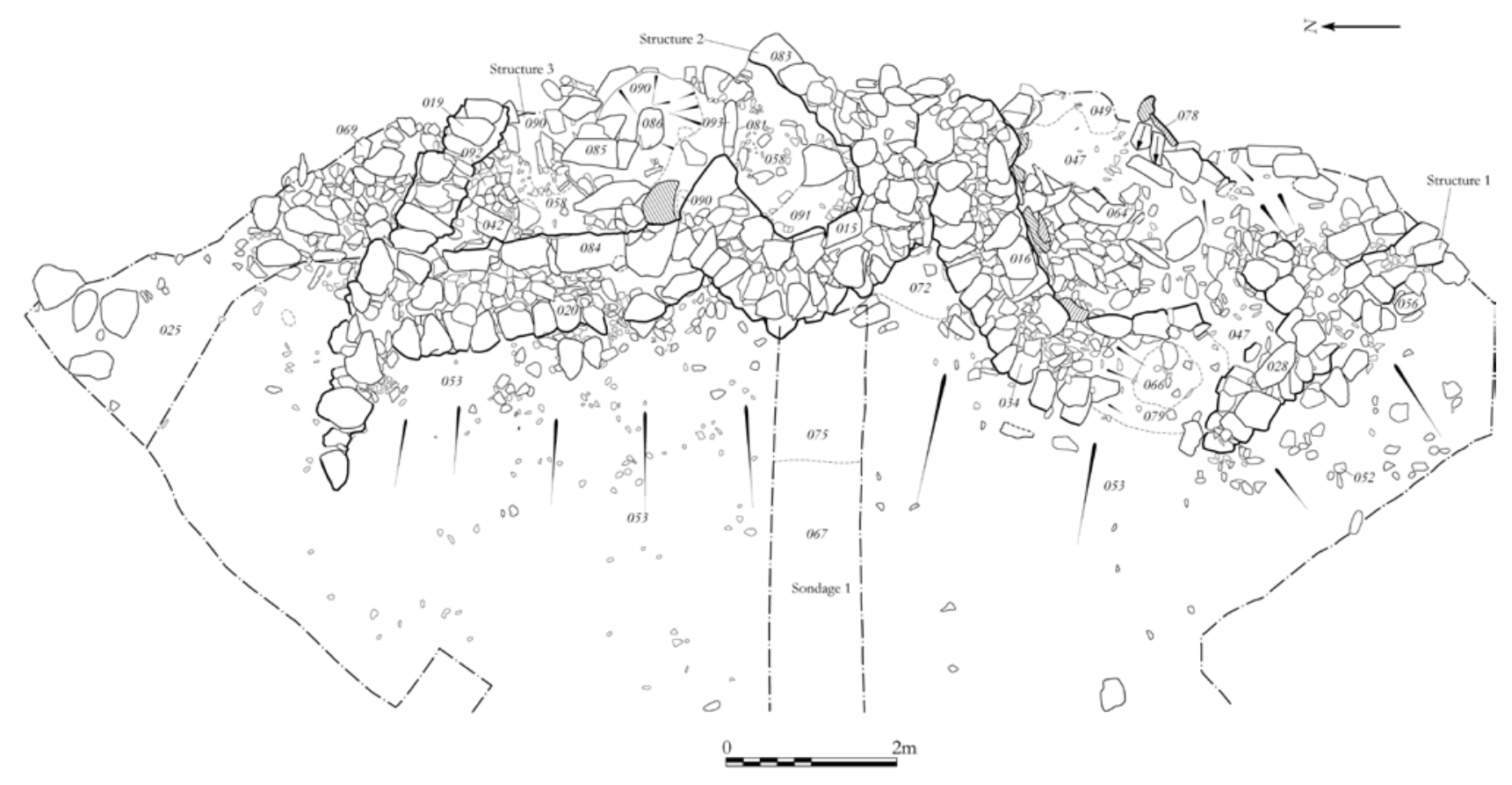

Illus 8 Plan of the structure at earlier phase

phasing evident in their walling, of the metalworking debris in structure 2, or of the traces of contemporary and post-abandonment activity outside them to the west, including the burial. This shows the value of the open-area excavation as opposed to tapestry excavation, at least in this case, and the skewed and erroneous intepretations to which tapestry excavation can lead.

In the case of the Sandwick mound, where the eroding face stood up to $1.8 \mathrm{~m}$ above the beach, health and safety considerations would also have made further tapestry excavation unfeasible. The stonework in the eroding section included large boulders in a loose, sandy matrix, and in some places no matrix at all. During the assessment, some of the boulders in a wave-damaged portion of walling slipped out of place, highlighting the section's unstable character. Open-area excavation through deep windblown sand carried its own health and safety challenges. To prevent the trench sides collapsing, they were excavated (by machine) with a batter of 30 degrees and covered with debris netting weighed down with sandbags to discourage downward movement of the sand. Some of the excavated sand was dumped onto the beach against the eroding face to stabilise it, reduce its height and provide a safe working platform for the excavation staff.

\subsection{TRAINING VOLUNTEERS IN COMMUNITY ARCHAEOLOGY AT SANDwick}

Of the 17 volunteers who participated in the 2005 excavation, seven had been involved in the 2004 assessment and three others also had some experience of working on an excavation. They included members of the Unst Amateur Archaeology Group and other Shetland's Past groups, and members of Shorewatch groups from Orkney and the Western Isles.

From the outset, we recognised that our ability to accommodate varying degrees of both experience and availability on the part of the volunteers would be key to the success of the training aspect of the project. The 2005 training programme was therefore designed to be flexible and to build on volunteers' existing skills and knowledge. Some of the skills taught during the assessment were directly transferrable to an excavation context - for example, an understanding of basic stratigraphic principles, recording methods and experience in section drawing all proved beneficial. The excavation training applied the same 'building block' formula as that employed during the assessment. Volunteers began by learning basic trowelling and identification skills, before being introduced to recording processes - both written and drawn.

In advance of the excavation, a field manual was produced which included an overview of the site and an outline of the work carried out in 2004. The rest of the manual detailed the basic methods and principles involved in excavation and recording, and included a glossary of common terms. The handbook allowed volunteers who had not participated in the 2004 season to familiarise themselves with the site and refreshed the memories of those who had. It was also designed to allow volunteers to digest what they learned on site at their leisure, and to understand their daily tasks within 


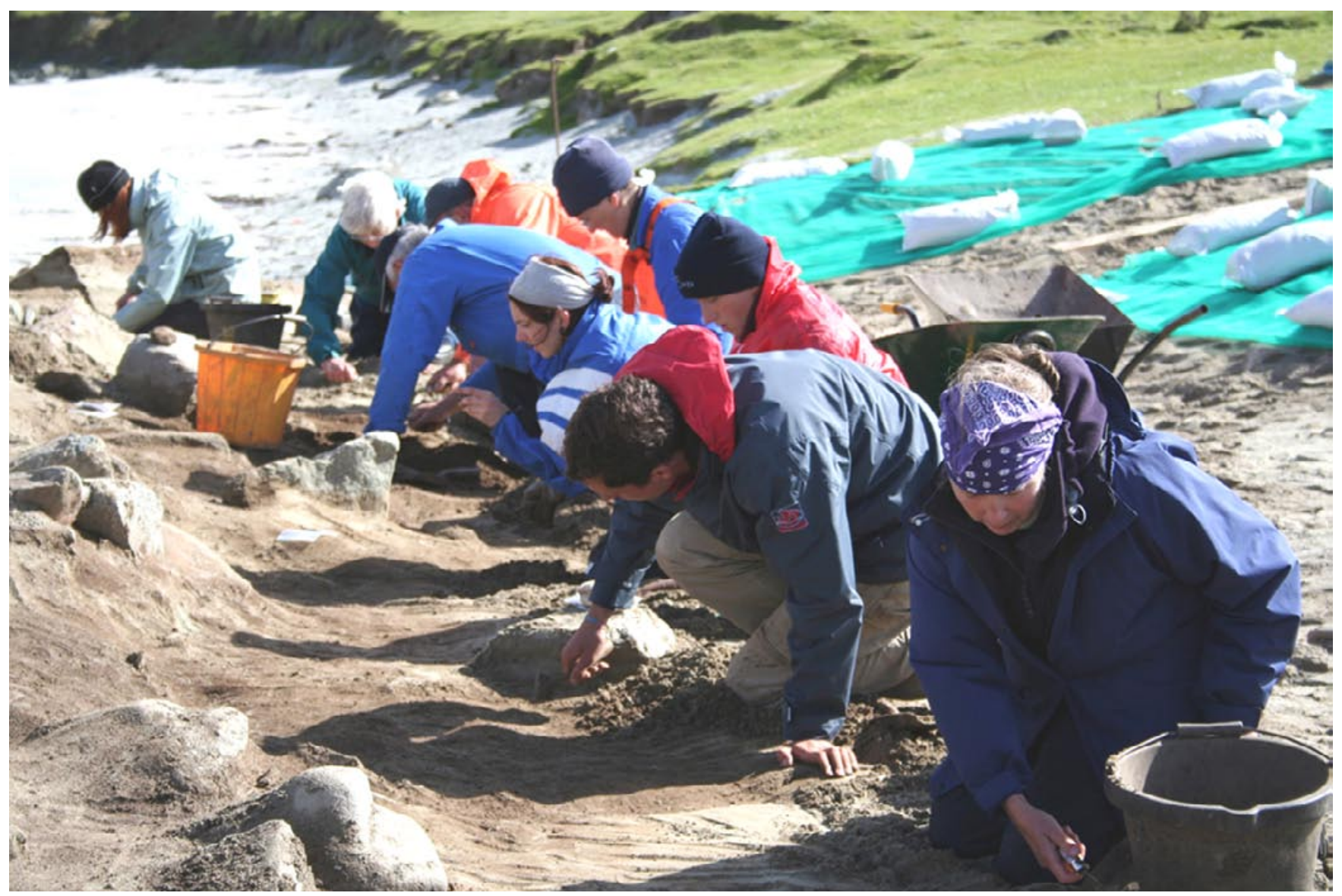

Illus 9 Members of the local groups trowelling at Sandwick, Unst

the wider context of fieldwork principles and best practice.

The on-site training consisted of

- trowelling skills and the identification of archaeological features, artefacts and ecofacts (illus 9)

- artefact recording, processing and basic conservation

- environmental sampling and processing

- the written record

- the drawn record

- site tours and visitor liaison skills

When volunteers arrived on site, they received a health and safety induction and a tour of the site. They were each given a copy of the manual and were asked about their previous experience in archaeology, their particular interests and what they hoped to gain from their involvement in the project. This allowed the training programme to be tailored, where possible, to meet individual needs, which was particularly important when someone had a limited amount of time available. As well as having a dedicated training director, the volunteers received close guidance from the professional excavators and supervisors on site. Two dedicated specialist supervisors oversaw the finds recording and processing and the environmental sampling and processing. Volunteers were assigned to each specialist supervisor on a rotating basis, usually for a day each (depending on how much time he or she could commit to the project), and would assist in all aspects of the recording and processing work.

Public outreach was an important aspect of the project, consisting of a site open day, an evening lecture, visits by local schools and an open doors policy to members of the public. Volunteers were on the whole very keen to assist with site tours, both on the open day and when casual visitors arrived. Giving tours helped to consolidate their knowledge of the excavation and also provided staff with an idea of the level of understanding each person was gaining. From the visitors' point of view, it provided a different, non-professional perspective on the site, and the possibility of encouraging other members of the community to join as volunteers in the second season.

The 2005 season also saw the creation and launch of the project website, http://www.shorewatch.co.uk/ unst. To operate effectively as a means of dissemination and presentation, a website must be usable, accessible and above all sensitive to its audience. Defining our key audience was therefore a major consideration. In this instance it was felt that the communities within Shetland, Unst and the Shorewatch groups around Scotland should be our primary target audiences. 
In terms of site content, all efforts were made to ensure that information was conveyed in an informal but informative manner. Technical terms were explained with consideration for the audience, and it is intended to provide a full hyperlinked glossary section in the near future. The pages contain a background to the project and a synopsis of the work conducted during the 2004 and 2005 seasons, including the 2004 Data Structure Report, available to download as a pdf. There is also a volunteers page, where the volunteers are given the opportunity to voice their thoughts on the project, contact details, an extensive image gallery, links to other local websites and a page of 'Kids' Stuff' with a gallery section including drawings from local schoolchildren and the activity sheet, which is available to download as a pdf.

The website will be revised and extended regularly, with updates on the findings from this year's season and other news. It is hoped that more resources and activities for school-age children will also be made available through the Kids' Stuff pages, providing groundwork for next year's education and outreach work.

The experiences of the 2005 season also revealed some pitfalls to avoid and lessons to be applied in the second season. The training director has to be entirely dedicated to training, having only peripheral involvement in the site's excavation, in order to properly attend to the volunteers' needs. An even more flexible approach would also enrich the volunteers' experience. Although every effort is made to give each volunteer a chance to learn and practice each aspect of field work, there are times when work on the site has to proceed without training - for example, during phases of intensive recording. At these times, volunteers can receive training in other aspects of fieldwork, such as detailed survey and interpretation of neighbouring monuments.

On the whole, both the excavation and training aspects of the Sandwick project have proved extremely interesting and rewarding, both for the professionals and the volunteers, and the presence of each has enriched the experience of the others. It has also shown that, with professional guidance and support, volunteers can play an extremely important part in the investigation and recording of eroding coastal sites. Indeed, involving volunteers in this way in future projects can both provide much-needed training and rescue valuable information that would otherwise be lost. 


\section{CONCLUSION}

People visit dunes regularly and it would be naive to think that they don't pick up or disturb interestinglooking objects exposed at the coast edge or within deflation hollows. Many people have been noting sites or actively collecting objects for years, and joining a Shorewatch or similar project allows them to harness their enthusiasm for the past. By encouraging inclusivity and actively involving members of the local community in practical projects, skills are transferred and, more importantly, the value of archaeological fieldwork and recording is demonstrated.

It is acknowledged that filling in recording sheets can be viewed as a tiresome chore, but if the reasons behind it are demonstrated in a practical way, the value is soon appreciated. In many cases, it is only after undertaking tasks over several days that group members learn why archaeologists insist on recording in meticulous detail. Not only can the local group members actively help archaeologists by locating and monitoring sites, they are also able to transfer their skills and knowledge throughout the community, explaining to others the value of archaeology and helping to safeguard threatened and vulnerable remains. 


\section{REFERENCES}

ASPIRE 2005 Archaeological Standard Protocol for the Integrated Reporting of Events. Aspire Project Team, Glasgow.

Beveridge, E 1903 Coll and Tiree: Their Prehistoric Forts and Ecclesiastical Antiquities, With Notices of Ancient Remains in the Treshnish Isles. T \& A Constable, Edinburgh.

Beveridge, E 1911 North Uist: its archaeology and topography; with notes upon the early history of the Outer Hebrides. William Brown, Edinburgh

Bigelow, G F 1978 'Unst, Norse-Medieval settlement', Discovery and Excavation Scotland, 18.

Bigelow, G F 1979 'Unst, late Norse settlement', Discovery and Excavation Scotland, 27.

Bigelow, G F 1980 'Sandwick, late-Norse settlement, pre-Norse burials', Discovery and Excavation Scotland, 26-7.

Bigelow, G F 1984 'Two kerbed cairns from Sandwick, Unst, Shetland', in J G P Friell \& W G Watson (eds), Pictish Studies: Settlement, Burial and Art in Dark Age Northern Britain. Oxford: BAR British Series 125, 115-30.

Brady, K J \& Morris, C D 1998 North Sutherland Survey: Coastal Zone Assessment (2 vols). Glasgow University Archaeological Research Division report 516/516.2, Glasgow.

Cressey, M \& Badger S 2005 Coastal Zone Assessment Survey Kintyre and the Isle of Arran. CFA Archaeology report 997, Edinburgh.

Cressey, M \& Johnson, M 2004 Coastal Zone Assess ment Survey Firth of Clyde and Isle of Bute. CFA Archaeology report 876, Edinburgh.

Dawson, T (ed) 2003 Coastal Archaeology and Erosion in Scotland. Historic Scotland, Edinburgh (available at www.historic-scotland. gov.uk/coastalconferenceproceedings).
Fraser, S, Gilmour, S \& Dawson, T 2003 'Shorewatch, Monitoring Scotland's Coastal Archaeology' in T Dawson (ed) Coastal Archaeology and Erosion in Scotland. Historic Scotland, Edinburgh.

Gilmour, S 2001 Shorewatch: Monitoring Scotland's Coastal Archaeology Pilot Phase 3 Final Report. Council for Scottish Archaeology archive report, Edinburgh.

Hansen, S S 1995 'Sandwick North (Unst parish), Norse farmstead' Discovery and Excavation Scotland, 105-6.

Historic Scotland 1996 Coastal Zone Assessment Survey: Archaeological Procedure Paper 4. Historic Scotland, Edinburgh.

Lelong, O \& Shearer, I 2004 Sandwick, Unst, Shetland: An Archaeological Assessment. GUARD Report 1833.

Lelong, O with a contribution by I. Shearer 2005 Sandwick, Unst, Shetland: Data Structure Report. GUARD Report 1969

Long, A 1996 Coastal Assessment Survey, Ullapool to Lochinver (2 vols). Unpublished report to Historic Scotland.

Moore, H and Wilson, G 2002 Report on a Coastal Zone Assessment Survey on the Islands of Coll and Tiree. EASE Archaeology archive report, Edinburgh.

Moore, H and Wilson, G 2003 Report on a Coastal Zone Assessment Survey of Islay. EASE Archaeology archive report, Edinburgh.

RCHME 1998 MIDAS:A Manual and Data Standard for Monument Inventories. National Monuments Record Centre, Swindon.

Sneddon, D 2003 Coastal Zone Assessment Survey Firth of Clyde. GUARD report 1309, Glasgow. 